NBER WORKING PAPER SERIES

\title{
THE RISE AND FALL OF THE WIDELY HELD FIRM - A HISTORY OF CORPORATE OWNERSHIP IN CANADA
}

\author{
Randall Morck \\ Michael Percy \\ Gloria Tian \\ Bernard Yeung \\ Working Paper 10635 \\ http://www.nber.org/papers/w10635
NATIONAL BUREAU OF ECONOMIC RESEARCH
1050 Massachusetts Avenue
Cambridge, MA 02138
July 2004

We are grateful for comments from participants in the National Bureau of Economic Research Conference on the History of Corporate Ownership in Lake Louise, the Canadian Economic Association in Ottawa, the INSEAD-University of Alberta- National Bureau of Economic Research Conference in Fontainebleau, and the Multinational Finance Society in Istanbul. We also thank seminar participants at the Bank of Canada, Hitotsubashi University, New York University, Queen's University, the University of Minnesota, and the University of Toronto's Olin Lecture. We are especially indebted to John Baldwin, Steven Globerman, Enrico Perotti, Ed Safarian, Andrei Shleifer, Jordan Siegel, and Javier Suárez for thoughtful comments and suggestions. Financial support from the University of Alberta School of Business, the University of Alberta Centre for Entrepreneurship \& Family Enterprise, and the Social Sciences and Humanities Research Council, is gratefully acknowledged. The views expressed herein are those of the author(s) and not necessarily those of the National Bureau of Economic Research.

(C2004 by Randall Morck, Michael Percy, Gloria Tian, and Bernard Yeung. All rights reserved. Short sections of text, not to exceed two paragraphs, may be quoted without explicit permission provided that full credit, including $\odot$ notice, is given to the source. 
The Rise and Fall of the Widely Held Firm - A History of Corporate Ownership in Canada

Randall Morck, Michael Percy, Gloria Tian, and Bernard Yeung

NBER Working Paper No. 10635

July 2004

JEL No. G3

\section{ABSTRACT}

A panel of corporate ownership data, stretching back to 1902, shows that the Canadian corporate sector began the century with a predominance of large pyramidal corporate groups controlled by wealthy families or individuals. By mid-century, widely held firms predominated. But, from the 1970s on, pyramidal groups controlled by wealthy families and individuals resurge, restoring a situation similar to that a century earlier. Institutional factors underlying this resurgence are shown to have antecedents deep in the country's colonial past.

Randall Morck

School of Business

University of Alberta

Edmonton, Alberta

Canada T6G 2R6

and NBER

randall.morck@ualberta.ca

Michael Percy

School of Business

University of Alberta

Edmonton, Alberta

Canada T6G 2R6

michael.percy@ualberta.ca

Gloria Tian

School of Business

University of Alberta

Edmonton, Alberta

Canada T6G 2R6

ytian@ualberta.ca

Bernard Yeung

Department of Economics

Stern School of Business

New York University

New York, NY 10012

byeung@stern.nyu.edu 


\begin{abstract}
A panel of corporate ownership data, stretching back to 1902, shows that the Canadian corporate sector began the century with a predominance of large pyramidal corporate groups controlled by wealthy families or individuals. By mid-century, widely held firms predominated. But, from the 1970s on, pyramidal groups controlled by wealthy families and individuals resurge, restoring a situation similar to that a century earlier. Institutional factors underlying this resurgence are shown to have antecedents deep in the country's colonial past.
\end{abstract}

\title{
1. Introduction
}

At the beginning of the $20^{\text {th }}$ century, large pyramidal corporate groups, controlled by wealthy families or individuals, dominated Canada's large corporate sector, as in modern continental European countries. Over several decades, a large stock market, high taxes on inherited income, a sound institutional environment, and capital account openness accompany the rise of widely held firms. At mid-century, the Canadian large corporate sector was primarily freestanding widely held firms, as in the modern large corporate sectors of the United States and United Kingdom. Then, in the last third of the century, a series of institutional changes took place. These include a more bank-based financial system, a sharp abatement in taxes on large estates, a likely rise in the value of superior rent seeking skills, and foreign investment restrictions. These were accompanied by a decline in the importance of freestanding widely held firms and a commensurate rise in the prevalence of family pyramidal groups.

The reasons for the relative decline in importance of Canada's stock market as compared to its banking system in the last decades of the century are unclear. The introduction of a capital gains tax at the onset of a period of high inflation may have been factors; but the stock market did not recover its prior level of importance after inflation abated.

The advent of the capital gains tax accompanied the end of succession taxes. After 1972, inherited income became tax exempt. Capital gains taxes were theoretically due on the decedent's assets at death. But the realization of capital gains could be postponed two generations through family trusts, structures viable only for very large estates. Several large family corporate groups were clearly broken into freestanding widely held firms to pay succession taxes, so the succession tax clearly accounts, in part at least, for the rise of the widely held firm.

The last third of the century actually saw much more profound transformations of public finances. Corporate taxes rose, and became intricately complicated, filled with implicit subsidies and intricate incentives and penalties. A proliferation of agencies administered a vast array of subsidies directly and through regional or industrial development funds. In a comprehensive study of Canadian public finances, Savoie (1990) concludes that "Especially since the early 1960s ... in certain areas of the country at least, there is a government subsidy available for virtually every type of commercial activity. He goes on to quote Canadian Business thus: "Some firms are in the happy position of being able to employ staff or consultants whose sole function is to sniff out all the juicy morsels the politicians and policy makers throw in the public trough."

Corproate groups are a response to a weak institutional environment. One version of this hypothesis, developed by Khanna and Palepu (2000, 2001, 2002), proposes that corporate groups are a second best solution in economies whose product, labor, and capital markets are underdeveloped and inefficient. Substantial evidence supports this explanation in emerging economies. A second version of this hypothesis, proposed by Morck and Yeung (2004), holds that family controlled corporate groups have superior political rent seeking skills. Political rent-seeking, corporate investment in political influence, is commonplace in most countries, and usually legal. Family groups' most important advantages include: Groups can act more discretely than freestanding firms, for one group firm can invest in influencing a politician while another, perhaps privately held, collects the reward. Family firms have long time horizons, and so can better invest in influence now to reap subsidies in the distant future. Widely held firms, in contrast, change CEOs every few years, and so require a faster payback. Thus, as political influence became an increasingly important determinant of financial success in the last decades of the century, family controlled group firms eclipsed freestanding widely held firms.

Finally, this rise of interventionism also entailed restrictions on foreign investment. Nationalist politicians, seeking to safeguard Canadian control of major corporations, perhaps encouraged family 
groups to serve as white knights. In some sectors, notably energy and cultural industries, this was overt locking in future subsidies and tax advantages. In others, the rewards may have been more indirect.

This heightened importance of political influence, and the nationalist overtones surrounding it, have resounding echoes through Canada's economic history. Jean Baptiste Colbert, the intellectual father of French Mercantilism, owned Canada and used the colony as a laboratory for mercantilist experiments. Colonial Canada featured state subsidized iron works, ship building, canals, brick making, shoe making, beer making, wool production, mining, lumbering, eel packing, sea oil, and cod salting, among many others. In general, these were owned by the colonial political elite (and Colbert), and subsidized by the French government. The British conquerors, appreciating the benefits of this system to the colonial elite (now themselves), preserved it. British North America repeatedly bankrupted itself subsidizing all manner of canal and railway projects owned, directly or indirectly, by colonial politicians. Canadian corporate investment continued in this vein long after independence, almost to the twentieth century. Around the turn of the $20^{\text {th }}$ century, the Liberal Prime Minister Wilfrid Laurier greatly reduced corruption and adopted laissez-fair policy (until near the end of his last term). The country enjoyed an unprecedented surge of development. After World War II, C.D. Howe, a powerful cabinet minister in a series of Liberal governments, professionalized the civil service and moved the country back towards laissez-faire. He also virtually monopolized the awarding of remaining subsidies and tax favors. In the 1960s, shareholder rights were formalized, and Canada's mercantilist past seemed buried. This corresponded to the greatest extent of large widely held freestanding firms - about eighty percent of the corporate sector by assets.

Two factors changed this in the late 1960s.

One was the Révolution tranquille in Québec, which reignited Canada's dormant linguistic quarrels and created a national identity crisis. Separatist politicians sought to build a Québécois nation with sweeping industrial policies. To counter this, federal politicians nurtured Canadian identity with nationalist rhetoric. This led to concern about foreign control of Canadian companies, and probably to Canadian family groups serving as white knights to safeguard widely held firms from foreign acquirers.

The second factor was a renewed political respectability for state intervention. Each previous political philosophy - the Tory rejection of the American Revolution, $19^{\text {th }}$ century liberalism, the progressive movement, and agrarian socialism in turn - quickly took on mercantilist garb upon touching Canadian soil. The Keynesian and social democratic philosophies of the 1970s were especially open to this. Canada's mercantilist undercurrent transformed idealistic plans to improve society into a morass of political rent-seeking. In this environment, family controlled corporate groups had an edge.

Thus, our findings support Burkart et al. (2002) and La Porta et al. (1999), who relate widely held ownership of corporations to sound institutions. They also support the general approach of Acemoglu et al. $(2000,2001,2002,2003)$, who stress the importance of colonial institutions in determining modern institutions. Our findings also give credence to the arguments of Morck and Yeung (2004) that family controlled corporate groups have an advantage in weak institutional environments because of superior rent seeking skills. However, they in no way undermine the thesis of Khanna and Palepu (2000, 2001, 2002) that other institutional deficiencies can also confer advantages on groups.

The remainder of the paper is as follows. Section 2 describes our ownership data. Section 3 describes Canada's colonial institutions. Section 4 describes institutions and large corporate ownership structures at the beginning of the twentieth century. Section 5 describes the evolution of large corporations ownership structures and proffers explanations. Section 6 concludes.

\section{Description of the Data}

To explore the evolution of corporate ownership, we require a picture of its initial conditions on the eve of industrialization. Continuous quantitative data are unavailable until the $20^{\text {th }}$ century; however, qualitative descriptions of business ownership are possible. Such descriptions are useful in assessing the influence of Canada's colonial heritages on her industrial era institutions, and in interpreting quantitative data in later years when it becomes available.

These qualitative descriptions summarize relevant parts of the writings of several business historians. Bliss (1986) presents a thorough review of Canadian business history that is broadly sympathetic to the country's business elite, emphasizing their entrepreneurial ventures and risk taking as 
well as their occasional skullduggery. Francis (1986) describes the increasing importance of business groups as of the early 1980s, and provides some historical information about the thirty largest groups. Hedley (1894) provides brief biographies of Canadian business leaders. Unfortunately, many are at too low a level to be of interest to us. Myers (1914) is something of a muckraker, focusing on the rentseeking, unsavory undertakings, and politically incorrect philosophies of the business elite. Naylor (1975) is quite critical of the business elite, and often appears sympathetic to leftist views. Taylor and Baskerville (1994) provide a highly useful history of Canadian businesses, though their coverage after 1930 is rushed. Tulchinsky (1977) provides information about colonial Montreal businesses. Parkman (1867) contains much information about Canada's colonial economy. All provide valuable information about ownership and control as asides to their main arguments.

Much of the qualitative description below relies on these sources - especially Bliss and Naylor for broad historical overviews and basic factual information. To avoid repetitive citations, specific references are mainly to other sources. However, a general reference pervades to these authors, and a degree of plagiarism is gratefully acknowledged.

Certain data on the health of the preindustrial and early industrial economy aides us in interpreting changes in corporate control. The Bay's dividend, available from 1670 on, reflects the health of the fur trade, and hence the colony's prosperity. Per capita GDP growth is available from 1870 on from Urquhart (1993) prior to 1926, and from Statistics Canada thereafter.

Annual data on merger and acquisition activity from 1885 can be concatenated from several sources. Marchildon (1990) provides a series from 1885 to 1918. Maule (1966) reports data from 1900 to 1963. The Royal Commission of Corporate Concentration provides data for 1970 through 1986. For 1985 through 2000, data are from Merger \& Acquisition in Canada.

Corporate financial records begin in 1902. ${ }^{1}$ Since these are not available from a uniform source over the full history of the country, we combine all available sources for each time period to produce the most accurate representation possible. Data for later years are probably better. For 1965 through 1998 we take the largest 100 companies, as listed in the Financial Post, ranked by assets until 1967, and by revenue thereafter. For earlier years, Financial Post rankings are unavailable, so we build our own rankings using annual report data, summarized in the Canadian Annual Financial Review for 1910 through 1940 and in Financial Post Corporate Securities for 1950 through 1960. ${ }^{2}$ We do not consider financial companies because these are not included in the top 100 rankings of the Financial Post, and because bank ownership structures are explicitly determined by federal legislation. ${ }^{3}$ Both state-owned enterprises and multinational corporations constitute significant fractions of the corporate sector through much of the $20^{\text {th }}$ century. We therefore consider alternative average ownership structures - including and then excluding state-owned enterprises, multinationals, and both.

A second is that the Financial Post ranks the top hundred firms from 1901 to 1965 by assets, and for later years by revenues. This appears to be because only consolidated assets are available for many companies in the earlier years. For later years, when both rankings are available, the use of sales and assets generates similar pictures. Consequently, this shortcoming is unlikely to affect our findings.

Our early ownership data are from several sources. Annual reports summarized in the Canadian Annual Financial Review and Financial Post Corporate Securities list the identity of any controlling shareholder, though not their equity stake. However, we find instances where these data contradict descriptions of corporate ownership in books on Canadian business history - especially Baskerville and Taylor (1994), Bliss (1986), Myers (1914), and Naylor (1975). In such cases, we assume beneficial ownership was not always clear at the time due to obfuscatory holding company structures. We rely on

\footnotetext{
${ }^{1}$ Incomplete data for 1901 are available.

${ }^{2}$ The only major data problem concerns Hydro One, formerly Ontario Hydro. Though established in 1906 as the Hydro-Electric Power Commission of Ontario (HEPC), and clearly an important state-owned enterprise throughout the century, it appears as a consolidated entity in the rankings only in 1970. From 1920 on, we estimate its assets and revenues by summing sectoral data in its annual reports. Earlier financial data is extremely disorganized and marred by apparent instances of double counting. We therefore use a geometric mean growth rate, estimated from 1920 on, to infer assets and revenues for earlier years. This certainly adds noise to our early figures for state-owned enterprises.

${ }^{3}$ The Bank Act proscribes any shareholder from voting more than ten percent of the stock in a chartered bank.
} 
the business historians to have sorted this out. One shortcoming inherent in using these descriptive sources, however, is that we cannot provide a clear cut definition of precisely what "controlled" or "member" of a corporate group means. A company is controlled by a family or belongs to a group if one of our historical sources says so, or if its annual report indicates so.

From 1965 on, securities laws require more detailed disclosure. Statistics Canada summarizes this in the Directory of Inter-Corporate Ownership (ICO), our primary source for these years. The Financial Post also provides the name and stake of the largest shareholder for top Canadian firms from 1970 s on. We define a company as controlled if there is a combined direct and indirect voting stake of ten percent or more, or if the ICO lists it as controlled. The ICO infers control in the absence of a ten percent stake if board control derives from director selection rules, golden shares, and the like.

Using all these data, we classify each company into one of the following categories: free standing widely held firms, free standing family controlled, family controlled pyramidal group firms, firms in pyramidal groups controlled by widely held companies, firms controlled by a government or government agency, firms with a controlling foreign shareholder, and firms we cannot classify.

\section{Colonial Origins}

Much work on economic and institutional evolution stresses the importance of early colonial institutions to economic and financial development. This literature stresses path dependence - the idea that where an economy was long ago defines the possible places it can be now. Recent work highlights several variants of path dependence.

Solokoff and Engerman (2000, p. 221) argue colonies with plantation economies, like the Caribbean Islands and Latin America, started off with tiny colonial elites directing large populations of conquered natives or imported slaves. These elites had no incentive to establish institutions, like land reform, education, banking systems, or stock markets, that would help create small businesses and a middle class. In contrast, the Unites States, especially north of the Chesapeake, was settled by yeoman farmers who demanded precisely those institutions. ${ }^{4}$

Acemoglu, Johnson, and Robinson (2001) explain the difference between such regions with settler mortality rates. They argue that yeoman farmers settled the United States because the climate of that region allowed them to survive. In contrast, European settlers in the Caribbean and much of Latin American died in droves. Consequently, the colonial powers minimized European settlement and built institutions that facilitated natural resource exploitation - mines and plantations. These sorts of institutions, once established, endured because their owners had sufficient wealth to control the political system. Acemoglu, Johnson, and Robinson $(2002,2003)$ propose a slightly different view - Europeans preserved extractive precolonial institutions where indigenous civilizations were more developed, like parts of Latin America and Asia.

Easterly and Levine (1997) point out that colonial era boundaries seldom correspond to linguistic or ethnic divisions, and use modern African data to show that ethnic diversity slows development. They find that ethnically divided countries have worse corruption, perhaps because of ethnic rivalry in tapping government coffers. Such countries also invest less in shared public infrastructure, perhaps because members of one group dislike funding projects the other group can share in.

Glaeser and Shleifer (2002) and La Porta et al. (1997, 1998, 1999, 2000) argue that events in their early history caused England, but not France, to develop laws that restrained elites, and hence that checked both official corruption and theft of outside investors' wealth by corporate insiders. In this view, most countries that inherited British Law, through colonization or transplantation, like the United States, developed dispersed corporate ownership; while most countries that inherited French Law, like Latin American, developed concentrated ownership. In general, they argue that British Common Law better facilitates financial development. King and Levine (1993) demonstrate a clear connection between economic growth to financial development. Thus, a legal system that restrains insider power promotes financial development, which permits development.

\footnotetext{
${ }^{4}$ Other work, notably Acemoglu et al. (2001, 2002, 2003), Engerman and Sokoloff (1997), Easterly and Levine (2002), Rajan and Zingales (2003), similarly highlights the importance of an egalitarian distribution of economic power before industrialization, so that institutional development does not entrench a small elite.
} 
Finally, Weber (1958) and others argue that elemental religious, cultural, and social factors direct economic development. Here again, Canada fails to fit nicely within any box. Québec remained profoundly Roman Catholic, and Anglophone Canada mainly Protestant, until the late $20^{\text {th }}$ century. Both are now stoutly secular. In a variant of this hypothesis, La Porta et al. (1997a) argue that societies in which people are more prone to act cooperatively with strangers are better able to build and sustain the large-scale public and private-sector institutions needed for long-term economic growth.

All of these authors argue that modern institutions, including corporate ownership, reflect these 'locked-in' historical factors. Despite their many cultural and historical similarities, Canada's colonial origins differ from those of other European settlements in North America. These differences relate to several of the above path dependence arguments, and exploring them is therefore a good starting point.

\section{L'Ancien Régime}

French Canada was initially a colony of resource extraction, not a colony of settlement. During brief periods when settlement became paramount, Canada was a theocratic society, reminiscent of modern Iran. And when settlement and development was finally pushed determinedly, Canada became a laboratory in which Jean Baptiste Colbert, the father of French mercantilist economics, tested his theories with development schemes similar to Third World misadventures in the 1960s. The values and ideals of French Canada still echo these centuries of theocratic and company rule, though in unexpected and sometimes odd ways.

Canada's history as a colony of extraction began in 1534, when Jacques Cartier mapped the St. Lawrence valley and claimed Canada for France. Seven years later, Francis I created Sieur de Roberval Viceroy of Canada. Roberval founded Québec in 1541, but abandoned it after a single winter. Although France had no permanent colony in Canada, merchants in Atlantic ports, like La Rochelle, ran regular fur trading ships to Canada. From 1562 to the 1598 Edict of Nantes, bloody Wars of Religion ruined France. Cut off from Paris, Catholic, Huguenot, and Jewish merchants in the Atlantic ports grew wealthy off a highly competitive fur trade.

The Edict of Nantes ended the civil wars by granting Protestants full rights, but France remained deeply divided. To reunite France, the state was tightly centralized around an absolute monarchy $-\mathrm{a}$ structure that persists, through various reincarnations, to the present. This centralization of economic power bade ill for the competitive fur trade.

Henry IV granted a monopoly to a group of merchants in 1600 and a ten-year monopoly to Sieur de Monts in 1604. De Monts sent Samuel de Champlain to found Port Royal (Annapolis, NS) in 1605 and rebuild Québec in 1608. De Monts renewed his monopoly once; then Champlain's Compagnie de Rouen et St. Malo obtained the sole right to trade furs. Rescinded in 1620 as the counterreformation swept France, the monopoly was transferred to Compagnie de Caen, run by the Rouen merchant William De Caen and his nephew. They established the feudal system in Canada, and the first fiefdom was granted in 1623 to Louis Hébert, whose Canadian title was Seigneur de Sault-au-Matelot.

All these monopolies were unenforceable until La Rochelle fell to the Royal Army in 1629. With the competition ruined, Cardinal Richelieu, Chief Advisor to the King since 1624, assigned his Compagnie des Cent Associés a permanent fur monopoly and limited monopolies on other transatlantic trades. In return, the Compagnie agreed to settle at least 300 habitants (feudal peasants) per year.

Now a Province of France, Canada had a Provincial Government run by the Compagnie des Cent Associés and a Conseil Souverain composed of the governor of Québec and senior Jesuits. The Conseil had lawmaking power over all Canada and subjected every aspect of the habitants' existence to the feudal order. Habitants were bound to the land, unable to marry without their seigneur's leave, and held no property save at their seigneur's pleasure. As the Holy Inquisition swept Catholic Europe, the Jesuits added an unforgiving Roman Catholicism to this mixture.

After Richelieu's death in 1642, the Compagnie quickly faded. The independent coureurs de bois seized the fur trade within Canada, and many grew rich. The same year, Sieur de Maisonneuve de la Société de Notre-Dame de Montréal founded that town as a missionary base. The Montréal clergy placed themselves above civil law and exercised their feudal powers and rights of tithe to accumulate great 
wealth. $^{5}$ This let the Canadian clergy and seigneurs take charge through a local council, the Communauté des Habitants, which soon controlled the Compagnie des Cent Associés.

This persisted until Jean-Baptiste Colbert, the intellectual father of Mercantilism, became Controller of Finance in 1661. Colbert used Canada to test his economic theories. ${ }^{6}$ In 1663, he formally dissolved the Compagnie des Cent Associés and replaced the Local Council with a new Conseil Souverain, charged with applying la Coutume de Paris, the ancien régime Civil Code, in Canada. ${ }^{7}$ Colbert appointed Jean Talon Intendant of Canada in 1665, and ordered him to diversify the economy. Usually with himself as the major shareholder, Talon subsidized brick making, shoe making, beer making, wool production, mining, lumbering, eel packing, sea oil, and cod salting. Talon's Conseil Souverain also imposed import restrictions and wage and price controls. He shipped les filles $d u$ roi, peasant women, to Canada to promote population growth. All this was subsidized by Colbert's ministry, the Departement de Marine, even though Canada was now a fief et seigneurie of the Compagnie des Indes Occidentals, controlled by Colbert. Ultimately, none of these initiatives (save perhaps the filles $d u$ roi ) proved viable.

Colbert's mercantilist experiments enriched a few local entrepreneurs. Charles Aubert de la Chesnaye, an agent in Canada for Rouen merchants, was probably the most important. He became a négociant marchand - a wholesaler, importer, exporter, financier, and moneylender. He backed loans with negotiable perpetuities, probably the first (informally) traded securities in Canada, and traded in feudal estates. In 1670, Chesnaye died deep in debt after a series of financial misfortunes.

In 1672, Louis de Buade de Frontenac et de Palluau, Comte de Frontenac, a young aristocrat seeking to evade his increasingly violent creditors, accepted the Governorship of Canada. (His pay was escrowed to his wife at court who slowly discharged his debts.) Frontenac continued Colbert's mercantilist projects and subsidized the Royal Army Engineers to build a scratchwork of canals. ${ }^{8}$

With Colbert's death in 1683, France focused on her new colony at Louisbourg, Acadia, near the Grand Banks and so more prosperous than Québec. But Colbert's mercantilist vision endured. The Intendants Bégon and Hocquart used state funds to subsidize a rope making operation, which quickly failed. Hocquart blamed a lack of investment capital among Canadian merchants for the colony's slow growth, and sponsored a shipyard and an ironworks, the latter a 1729 proposal of François Poulin de Francheville, Seigneur de St. Maurice. Both, and the rope works, soon failed due to prohibitive costs and clouseauesque quality control. Olivier de Vézin, an engineer, redeveloped the ironworks as $L a$ Compagnie des Forges du Saint-Maurice with further government money in 1737. Lunn (1942) describes the result:

"Indications of the disaster which was to overtake the enterprise were evident from the beginning ... . By October 1737, when the establishment was announced to be complete, the total expenditure was 146,588 livres instead of the 100,000 estimated ... . In 1737 Hocquart had made over to the company the remainder of the loan of 100,000 livres agreed upon, but the partners declared they must have an additional 82,642 livres. Their need was so pressing that Hocquart took it upon himself to advance them 25,233 livres, to be deducted from the 82,642 livres which he begged the Minister to lend ....

"The Minister replied in accents of horror and indignation. ... It seemed clear to the Minister that there had been much waste and extravagance. Nevertheless, he did consent to the new loan .... .

"Further shocks were in store for the minister. In 1738, the company foresaw that it would not be able to meet its first payment due in 1739 and the King had to agree to yet another year's delay. ... De Vézin's estimate had proved completely unreliable, for expenses far exceeded and production fell far short of what had been anticipated ... Constant breakdowns of the furnace interfered seriously with production ... The Forges were operated by a staff of costly, dilatory, insubordinate and discontented workmen."

\footnotetext{
${ }^{5}$ Myers (1914) chapter 2.

${ }^{6}$ For a details of these subsidized diversification programs, see Fauteux (1927) and Bliss (1986).

${ }^{7}$ The Coutume de Paris granted the Canadian nobility the full feudal rights of the nobility in France, including the power of haute justice over their habitants.

${ }^{8}$ See Bliss (1986).

${ }^{9}$ Quoted in Bliss (1986), p. 65.
} 
La Compagnie des Forges du Saint-Maurice sank in 1741, pulled down by engineering, managerial, and financial farce. The state took over the forges and shipyards. The latter posted regular losses until long after the Conquest. None of these mercantilist projects stopped Canada's drain on the Royal Treasury. Exports exceed imports only once in the entire history of the colony, in 1741. The most consistently profitable business was the Société $d u$ Canada, run by the Huguenot merchant Robert Dugard, which shipped staples to Canada.

Britain and France wrestled for control of Canada in the War of the Austrian Succession (1740 to 1748) and the Seven Years War (1755 to 1763). Louisbourg fell to Britain in 1758, and Québec in 1759. With the 1763 Treaty of Paris, all Canada passed to Britain. Blamed for the loss in L'affaire du Canada, the last Governor, de Vaudreuil, the last Intendant, Bigot, and other senior Canadian officials moldered in the Bastille for "corruption."

\section{British North America}

Henry Hudson's 1610 claim for Britain to the lands around Hudson's Bay lay unexploited until 1670, when Charles II granted his cousin, Prince Rupert, a fur trade monopoly and rechristened the region Rupertsland. Rupert organized The Company of Adventurers of England trading into Hudsons Bay (a.k.a. The Hudson's Bay Company, or 'the Bay'), a joint stock company, to raise funds. ${ }^{10}$ The forts, trading posts, and ships required - as well as the risks inherent in the fur trade - were beyond the resources of even the wealthiest individual families. Thus, the Hudson's Bay Company, like the British East India Company and the Dutch East Indies Company, was among the first joint stock companies formed. Figure 1, showing the company's annual dividend, is a barometer of the prosperity of the fur trade and, later, of the Canadian economy. From 1670 to the War of the Austrian Succession, British interests in Canada consisted of the Bay's scattered trading posts and little else.

Figure 1. Hudson's Bay Company Annual Dividend, 1670 to 2000 Expressed as percent of par value until 1970 and as a percent of equity market value from 1961 to 2000.

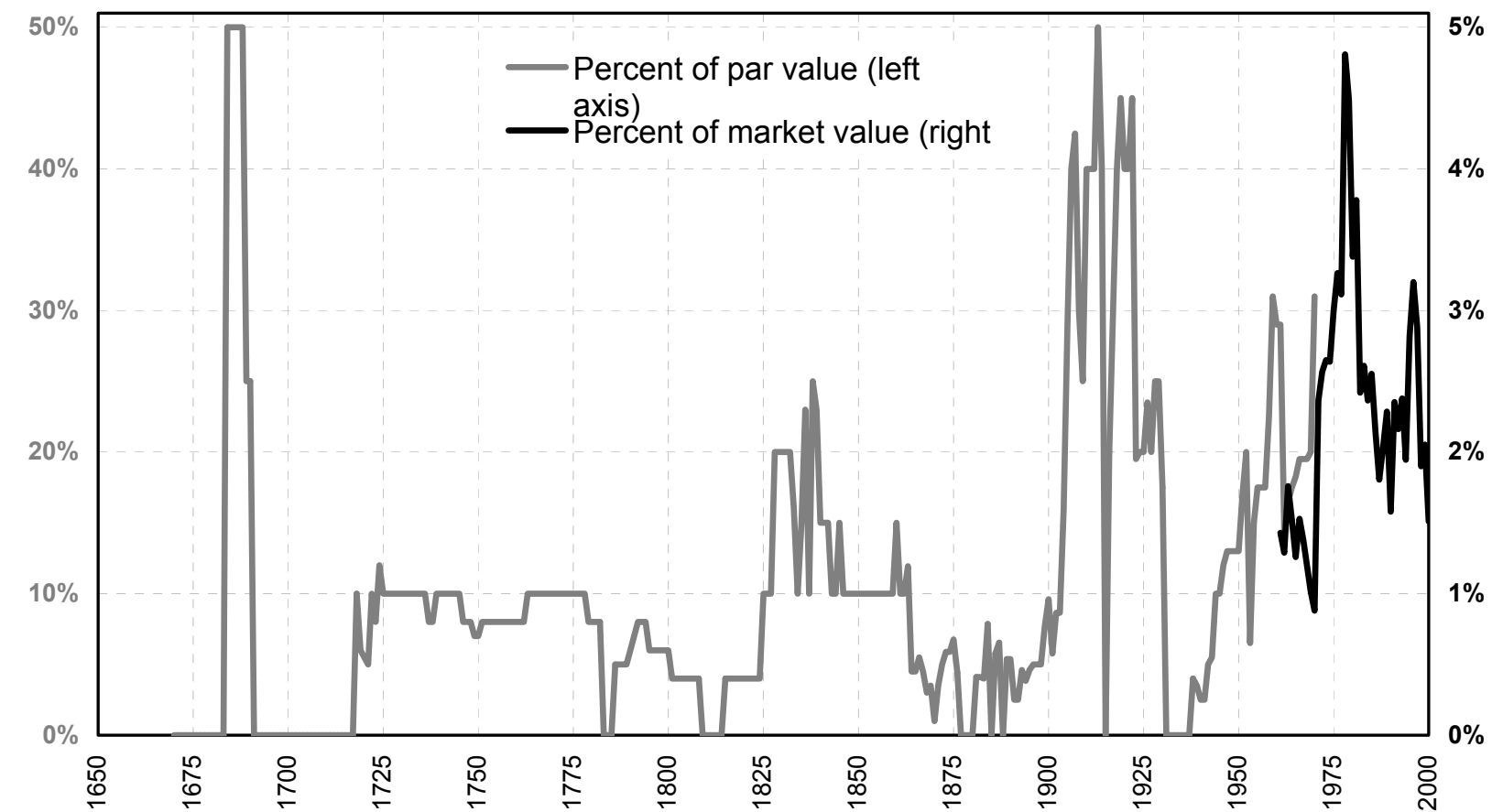

Source: Newman (1998) and Financial Post Historical Report for Hudson's Bay Company.

\footnotetext{
${ }^{10}$ The Company was empowered to employ an armed force, appoint commanders, erect forts and take other necessary measures to protect its property. See Myers (1914) chapter 3. The Bay still exists as a chain of department stores.
} 
After the Seven Years War, a deeply corrupt British colonial government took control of Canada. ${ }^{12}$ Colonel Talbot, General Brock, and Bishop Mountain all seized vast tracts of Upper Canada (Ontario), while the Governor, Henry Hamilton, Judge Elmslie, Judge Powell, and Solicitor General Gray appropriated huge swaths of Lower Canada (Québec). All of Prince Edward Island was divided up by the Montgomery, Selkirk, Westmoreland, Cambridge, Macdonnell, and Seymour families.

Partially in response to such abuses, London suspended British Common Law in Canada in 1774, restored the French Civil Code of the ancien régime in property law and all matters except criminal cases, and extended the boundaries of civil law application to all of British North America north or west of the Appalachians. This seems to be because civil law better restricted land grabs by the local elite. However, French feudal land tenure and civil law were now firmly rooted in British North America.

A tax rebellion, these restrictions on land claims west of the Appalachians, and an elite deeply indebted to British merchant houses combined to inspire rebellion in the thirteen coastal colonies in 1776. This conflict was essentially a civil war, with at least a third of the colonial population remaining loyal to the Empire. French intervention allowed a secessionist victory, and revolutionary governments took power in the thirteen colonies. Revolutionary tribunals confiscated the property of those on the losing side and exiled them. In one of history's largest forced displacements, hundreds of thousands of impoverished United Empire Loyalist refugees straggled north. ${ }^{13}$ In a few short years, Canada was transformed from a Francophone country into a half-English half-French country.

Loyalists settling in Canada disliked the French Civil Code and coveted land. In 1791, their lobbying partitioned Canada into Upper Canada (Ontario) and Lower Canada (Québec). In 1793, Chief Justice Osgood restored Common Law in Upper Canada (Ontario). Upper Canada's Governor, Robert Prescott, and Lieutenant Governor, John Graves Simco, stalwartly upheld directives from London to hold land open for settlement. By 1794, Osgood forced both from office and installed Sir Robert Shore Milnes as Governor and Peter Russell as Lieutenant Governor. Together they apportioned virtually all remaining unclaimed land to a tiny elite of leading Loyalist families, later called the Family Compact.

The Family Compact's dominance is hard to exaggerate, as is its success in retarding economic development. ${ }^{14}$ As absentee landlords, the families opposed settlement and roads for fear of losing title to squatters. Their control of the legislative and executive councils, the Church, and colonial courts let them safeguard their interests regardless of the effect on the economy's overall development.

The influence of the so-called Chateau Clique in Lower Canada was narrower, and so less effective at braking growth. In 1779, British and Loyalist merchants in Montréal established the Northwest Company to compete with the Hudson's Bay Company for the fur trade, contesting the legitimacy of the latter's monopoly. The original founders of the Northwest Company included Simon McTavish, Todd and McGill, Charles Grant, Benjamin and Joseph Frobisher, the firm of McGill and Patterson and five other merchants and firms. ${ }^{15}$ The resulting wealth gave the same names prominence in banking, shipping, and railroad promotion decades later.

Since the Hudson's Bay Company had its own militia, the Northwest Company needed one too. Their battle for market share is best described in military terms. The results are also evident in Figure 1 in the reduced dividend of the HBC.

During this period, the most entrepreneurial regions of British North America were the Maritime Colonies - Nova Scotia and New Brunswick. Abraham Cunard, a master carpenter, arrived in Halifax in 1783 and rapidly established stores, mills, lumbering, sawmills, shipbuilding, an accounting firm, and other businesses. Despite strong competition from other "timber barons" like Gilmour, Rankin, \& Co., Philemon Wright \& Sons, William Price, and John Egan, A. Cunard \& Son prospered. Many timber barons, including Christopher Scott, John and Charles Wood, and the Cunards, expanded into shipbuilding and shipping. Bliss (1986, p. 135) remarks that all of these fortunes were technically founded on theft, for the timber was almost all harvested from Crown land. The Cunard Line prospered, especially after it obtained a monopoly on delivering the Royal Mail between Britain and the Americas.

\footnotetext{
${ }^{12}$ For details of specific corrupt dealings, see chapter 5 of Myers (1914).

${ }^{13}$ The precise number of Loyalists is disputed by historians.

${ }^{14}$ See Myers (1914) chapter 6.

${ }^{15}$ See Myers (1914) chapter 4.
} 
In 1812, the Napoleonic War engulfed the Canadas as an American invasion force burned Toronto and despoiled farms and villages. Figure 1 illustrates the disruption of the fur trade in the elimination of HBC dividends. The French and their American allies defeated, the inflow of settlers resumed. Although a new British colony was established in Manitoba in 1811, its remoteness, and the Bay's unwillingness to grant settlers formal property rights, deterred settlement. ${ }^{16}$ The Bay viewed farmers as disruptive of its trading relations with Indians, and effectively prevented further westward expansion of settlement. Thus, immigrants remained in the Canadas and the Maritimes.

The economy grew faster in Lower Canada, where the Chateau Clique exercised a looser dominance than did the Family Compact in Upper Canada. Montréal, closer to the Atlantic and the coastal colonies, emerged as the economic center of Canada. In 1821, the Bay absorbed the Northwest Company. The costs of their militarized competition had grown, in both money and death toll, and Figure 1 illustrates the advantages of a fur trade monopoly. The former principals of the Northwest Company in Montréal, the McGills, MacTavishes, Frobishers, Grants, and others, now had considerable wealth to invest in other ventures.

The House of Phyn, Ellice \& Co. established a branch in Montréal in the late 1770s to finance the staples trade, and so was the first bank in Canada. The Napoleonic Wars disrupted this business, and once peace was restored, John Richardson and Horatio Gates, the Montréal principals of Phyn, Ellice and Co., established the Bank of Montréal as a partnership. The Bank of Montréal subscribed to the real bills doctrine, and issued dollar banknotes backed by the staples trade, thereby establishing the currency unit for Canada. Rival banks quickly formed in Lower Canada, but the Bank of Montréal, soon run by Peter McGill, remained dominant. The Bank of Nova Scotia was chartered in 1832 in Halifax as the first limited liability joint stock company in what would become Canada.

John Molson, a young Englishman, arrived in Montréal in 1785 and invested his inheritance in a brewery. This continually profitable venture let him finance the first steamship in 1809. Although Molson lobbied for a steamship monopoly, he was unsuccessful and a brisk competition ensued. Profits from his brewery let him underprice the competition, and eventually buy most out.

The main competition would ultimately be the Allan Line, run by Hugh Allan, a partner in his father's Scottish shipbuilding and merchant firm, Edmonstone, Allan \& Co. With family money, Allan launched the Montréal Ocean Steamship Co. in 1852, and immediately reaped great profits transporting troops to the Crimean War. Bliss (1986) reports that "Allan ships sank, ran aground, and broke up with astonishing frequency", but that he courted politicians generously, and was a recognized master of political influence. By the $1860 \mathrm{~s}$, the Allan Lines safety record was improving, and the family was growing rich bringing steerage immigrants to North America. ${ }^{17}$ According to Myers (1914), Allan served as president of fifteen corporations and vice-president of six others at the zenith of his career - in industries spanning telegraphy, navigation, iron, tobacco, cotton manufacturing, railways, sewing machine, cattle, rolling mills, paper, cars, elevators, and coal. His Montréal Warehouse Company undertook land speculation. ${ }^{18}$

In 1838, Joseph Howe, a Nova Scotia colonial leader, lobbied the Royal Mail to switch to steam delivery, and the Admiralty invited tenders. Although none of the responses met the Admiralty's conditions, Samuel Cunard, Abraham's eldest son, now running the family business, won the contract apparently through his influential friends in England, including Lady Caroline Norton, the mistress of Lord Melbourne, then the British prime minister. This guaranteed mail business gave the Cunard Line a critical edge over its competition, the Inman and Collins lines. Both modernized rapidly, switching to screw-driven ironclads at great expense, and ultimately failed. Cunard modernized more slowly, and, as

\footnotetext{
${ }^{16}$ Myers (1914) describes an 1857 a petition signed by Red River settlers to London describing how they had "paid large sums of money to the Hudson's Bay Company for land ... yet we cannot obtain deeds for the same. The Company's agents have made several attempts to force upon us deeds which would reduce ourselves and our posterity to the most abject slavery under that body...."

${ }^{17}$ The Allan Line sued the Montreal Witness, a newspaper that ran stories about the filth and overcrowding in its steerage compartments, for libel. In 1883, shortly after Allan's death, the jury, after hearing all of the evidence during a trial of eight days, returned a verdict in favor of the Montreal Witness on all counts. For details, see Monetary Times, Nov. 2, 1883 p. 491.

${ }^{18}$ Myers (1914) chapter 12.
} 
Bliss notes) profitably delivered the Royal Mail between London, Halifax, New York, and Boston in wooden steamships.

The Bank of Upper Canada, controlled by the Family Compact, exercised a near monopoly in that colony. ${ }^{19}$ In 1825, John Galt, a novelist, organized the Canada Company to resell land to immigrants; but such entrepreneurial ventures were notable in their rarity. ${ }^{20}$ Some outsiders, notably the Scottish immigrants Isaac and Peter Buchanan and their Ulsterman partner Robert Harris, got Bank of Upper Canada backing and grew rich off the Upper Canadian staples trade. But Isaac recalled that

"The wonderful success of my operations in Canada may be to a great extent attributed to my solemn determination not to trust Yankees and my exercising the most vigorous scrutiny before doing business with a man Canadian born ..."

The biggest enterprises in Upper Canada in the early $19^{\text {th }}$ century were canals. The government built the Rideau Canal from the Ottawa River to Lake Ontario. William Hamilton Merritt organized the Welland Canal, linking Lake Erie and Lake Ontario, as a joint stock company controlled by the Family Compact. After providing generous state subsidies and loans, the Upper Canada government finally bought out the owners of the failing venture in 1841. The newspaperman William Lyon Mackenzie charged that the whole project was a scam to enrich the Family Compact. Upper Canada's public finances never recovered.

In 1832, railroad stocks began trading in a café in Montréal that eventually became the Montréal Stock Exchange. The Champlain and St. Lawrence Rail Road was built in 1834 with backing from the Molsons, Horatio Gates, and Peter McGill, then the president of the Bank of Montréal; and financing for other railroads was undertaken.

But complaints about gross corruption and abuse of office by the elites of both Canadas grew louder. Denied political influence and economic opportunities, new immigrants formed an opposition movement that ultimately coalesced into the Reform Party. Francis Bond Head, Governor of Upper Canada from 1835 to 1837 cracked down with a policy of "order and discipline". His refusal to permit the suspension of specie payment during the Panic of 1837 caused the Bank of Upper Canada to call in debts ruthlessly throughout the colony, further infuriating the populace. Lower Canada fractured along linguistic lines.

Open rebellion broke out in 1837, as Louis-Joseph Papineau declared a Republic in Lower Canada and William Lyon Mackenzie did likewise in Upper Canada. ${ }^{22}$ Demanding an end to feudalism, church estates, trade barriers, and land reform, the rebels had strong popular support. ${ }^{23}$ Although the army restored order, Upper Canada debentures collapsed. London dispatched a new governor, Lord Durham, whose 1839 report damned decades of fraud and theft by the colonial elite and recommended Responsible Government - democratic home rule. ${ }^{24}$

The end of the Imperial Preference in 1846 exposed Canadian merchants to free trade. The economy collapsed, and Lord Elgin, the Governor General of Canada, reported in 1849 that

"Property in most Canadian towns, and most especially in the capital [Montréal], has fallen 50 percent in value within the last three years. Three fourths of the commercial men are bankrupt. ${ }^{25}$

In the London markets Canada's standing, battered by the rebellions of the late 1830s, collapsed

In 1849, responding to Durham's report (and British bondholders), London merged bankrupt Upper Canada and fiscally sound Lower Canada to form a united, solvent, Province of Canada with home rule. In response, a Tory mob burned parliament. But Canada now had a Prime Minister responsible to

\footnotetext{
${ }^{19}$ See Baskerville (1987).

${ }^{20}$ Browde (2002).

${ }^{21}$ Bliss (1986) p. 154.

${ }^{22}$ Although Nova Scotians increasingly resented the appointed Council of Twelve (Cunard and other merchants) that ran that colony, democratic reform came peacefully there.

${ }^{23}$ See Myers (1914).

${ }^{24}$ See Lambton (1838) Vol. X for a description of the abuses.

${ }^{25}$ Bliss (1986) p. 158.
} 
an elected legislature. Still, since an Imperial guarantee was needed to float Canadian debt, the Imperial Government appointed the London investment houses of Barings and Glyns to oversee the colony's finances.

In 1844, Alexander established the Sherbrooke Cotton Mill, Canada's first industrial joint stock company, and more investment opportunities emerged as the colony's politics stabilized. Perhaps the most important development policy of the new united province was the new 1849 Patent Act, which forbade Canadian patents on American technology, creating multitudes of openings for local entrepreneurs capable of using such know-how.

The colony's political leaders felt hamstrung by their inability to subsidize such new ventures. Francis Hincks, an entrepreneur and Member of Parliament, partially solved this problem with a new Municipalities Act, which let towns float debt. A more complete solution appeared in 1849, when Canada began guaranteeing railroad debt, but only if prominent politicians, such as Hincks and Galt, were on the board to "guarantee good management." After a brief financial crisis in 1849, a boom and bust in railroad stocks ensued, and railroad construction resumed on a grand scale. Although railroads built honest fortunes, like that of the engineer Casimir Gzoski, corruption was endemic. ${ }^{26}$ Sir Allan Napier $\mathrm{MacNab}$, president of the Great Western Railway, served Canada as chair of the Parliamentary Standing Committee of Railways and Telegraphs. ${ }^{27}$ The grandest project, the Grand Truck Railroad, run by Prime Minister Hincks, was ineptly built and almost unusable. ${ }^{28}$ A British lobbyist hired by Hincks to lobby members of parliament wrote:

I do not think there is much to be said for Canadians over Turks when contracts, places, free tickets on railways, or even cash was in question. ${ }^{29}$

A Barings investigation exposed rampant fraud, kickbacks, and deceit; and Barings blocked further Canadian listings in London to obtain a veto over additional debt financing and guarantees in 1851. This merely tested the ingenuity of the colonial political elite in circumventing such checks. Railway subsidies became a top government priority. According to Naylor (1975), railroad construction and financing in colonial Canada were "appalling even by the standards of the day." Virtually every important politician now moonlighted as a railway officer or director, and railway subsidies both enriched political insiders and drained government coffers. Current, past, and future Prime Ministers Francis Hincks, Alexander T. Galt, and John A. MacDonald, respectively, and most of their cabinet ministers all had railway financial ties. ${ }^{30}$ In 1858, Alexander Galt, now Finance Minister, subordinated Canada's sovereign debt to railroad common stock and raised the tariff to obtain funds for larger railway subsidies. By the $1860 \mathrm{~s}$, Canada had both a shoddily built, poorly run railroad system and a near bankrupt government.

Now, only union with the solvent Maritime colonies of Nova Scotia and New Brunswick promised fiscal rescue. When the United States abrogated the Reciprocity Treaty in 1866, Galt lowered the tariff slightly on manufactured goods to match those of the Nova Scotia and New Brunswick colonies, in preparation for their union with Canada. In 1867, British investors blocked New Brunswick and Nova Scotia financing in London to force such a union. The resulting confederation was the Dominion of Canada, a self-governing entity within the British Empire. Canadian independence is usually dated to 1867, though Responsible Government came earlier and Canada remained within the Empire long after. Since the Canadian parliament assumed almost all of the powers of the parliament in London in 1867, this date is probably more appropriate than any other.

Despite endemic corruption worthy of the worst modern Third World economies, the economy modernized. Alexander Galt formed the British American Land Co. in 1831 to buy feudal estates in

\footnotetext{
${ }^{26}$ See Myers (1914) chapters 10 and 11 for a detailed description of specific allegations and evidence, including the report of the 1876-1877 Select Parliamentary Investigating Committee. Mills (1872), a Member of Parliament, writes that "Corruption taints the majority of railway enterprises from their inception to completion" and provides details.

${ }^{27}$ Bliss (1986) p. 186.

${ }^{28}$ Myers (1914) c. 11.

${ }^{29}$ Bliss (1986) p. 187.

${ }^{30}$ Myers (1914), Bliss (1986).
} 
Lower Canada and sell small homesteads to English settlers, much as John Galt, his father, had in Upper Canada. ${ }^{31}$ Thus, land reform proceeded through private sector initiative. The Toronto Stock Exchange, founded in 1854 primarily as a commodity exchange, now traded railroad stocks and even a few other companies. Free trade, though originally disruptive, now let Canada benefit from elevated wheat prices during the Crimean War. An 1854 Reciprocity Treaty (free trade) with the United States further stimulated the economy. Also in 1854, Prime Minister Hincks bought out the remaining seigneurs of Lower Canada, finally ridding Canada of the feudal system. ${ }^{32}$ Although slave sales were abolished in 1797, French Canadian habitants emerged completely from feudal serfdom only a few years before the US Civil War. In 1866, Lower Canada replaced la Coutom de Paris Civil Code with the Lower Canada Civil Code, an updated version of the Napoleonic code, and adopted Common Law for certain commercial and maritime disputes.

\section{Canada on the Eve of Industrialization}

All of this invites comparison with the theories, outlined above, of colonial origins determining subsequent institutional and economic development.

Canada, though ultimately a colony of settlement, was long a colony of resource extraction. The core industry through the mid $19^{\text {th }}$ century was the fur trade - natives selling pelts to Europeans stationed in a dispersed network of Bay trading posts. The Bay actively opposed colonization for fear that yeoman farmers would disrupt relations with Indian and Métis trappers. Agriculture in French Canada was organized into feudal estates modeled on those in pre-Revolutionary France. The early British elite, especially the Family Compact, emulated this by monopolizing land claims. Overall, the early history of Canada thus resembles Solokoff and Engerman's (2000) description of Caribbean and Latin America colonial economies.

The Canadian climate, though harsh, was not deadly to Europeans, and the French eventually switched their emphasis, in part, to settlement. This was accompanied by extensive mercantilist state intervention and corruption under the French colonial regime. Their British successors preserved much of this institutional heritage, even as Loyalist refugees flooded the colony. Thus, an exogenous political event, the succession of the thirteen coastal colonies, irrevocably converted Canada into a colony of settlement, increasingly populated by yeoman farmers who demanded, and ultimately got, legal protection from the colony's elite. Canadian economic history permits a deeper understanding of the results in Acemoglu, Johnson, and Robinson $(2002,2003)$. An environment in which European settlers could survive did not per se trigger rapid settlement. However, once large-scale British settlement occurred, pressure for British institutions ensued after a few decades, consistent with a broader interpretation of their thesis: institutional development is determined by the settlers' preference.

Easterly and Levine (1997) find that ethnic diversity slows development. The longstanding French-English rivalry in Canada might well have slowed Canada's overall growth, for arguments about each linguistic group's access to government cash flows were central to the debates leading up to Home Rule in 1848 and Confederation in 1867. However, ethnically divided Lower Canada was certainly more dynamic than thoroughly Loyalist Upper Canada with its Family Compact earlier in the $19^{\text {th }}$ century. Factors other than linguistic divisions were clearly at work as well.

La Porta et al. $(1997,1998,1999,2000)$ demonstrate a clear correlation between the use of legal systems derived from British Common Law and fuller financial and institutional development. The early stages of economic development reveal no clear superiority of British over French law. Corruption occurred under both. Although Canada adopted aspects of Common Law in fields relevant to business corporations, French Civil Law still remains important in Québec. Montreal remained the country's economic center of gravity until the $20^{\text {th }}$ century, so early Canadian businesses functioned in a hybrid legal environment combining Civil and Common Law. La Porta et al. argue that official corruption and insider abuse of investors are more limited by the British than the French legal system. Canada has a venerable tradition of state subsidies to politically connected businesses that we would now characterize as corruption. This may echo Canada's French heritage; but if more than a century of British colonial

\footnotetext{
${ }^{31}$ Dowde (2002).

${ }^{32}$ Myers (1914) makes much of the generous terms of the buyout in contrast to the conditions under which feudalism ended in France in 1789.
} 
rule failed to silence these echoes, adopting British legal systems is hardly a viable development strategy for today's emerging economies. Alternatively, the La Porta et al. findings may pertain to an effect of British Common Law on later stages of industrialization.

Certainly, the half century after widespread British settlement and the establishment of British institutions saw Canada successfully transform from a sparsely populated feudal wilderness into a country with farms, cities, canals and railways. Land development schemes opened new feudal estates to settlement. The foundations of great business dynasties were laid. While there was clearly enormous waste and theft, this deeply corrupt political economy nonetheless advanced to the earliest stages of industrialization. These observations raise questions about the current condemnation of "corruption" as inimical to development in the third world. Canada's colonial heritage renders the hypothesis that sound institutions are a consequence of growth, rather than its cause, at least worthy of serious thought.

Canadian economic history also provides further insight into the argument of La Porta et al. (1997a), that more hierarchically organized societies have difficulty accommodating institutional development. French Canada was founded by Cardinal Richelieu, subjected to the full force of the counter-reformation, and remained deeply subservient to the Roman Catholic hierarchy until the mid $20^{\text {th }}$ century. That hierarchy generally dealt with the English elite on their behalf after the Treaty of Paris. English Canadians whose family histories recall revolutionary tribunals and armed debtors can value "peace, order and good government" to an extent that foreigners and more recent immigrants find hard to fathom. This deference perhaps allowed the Tory elite to adapt the mercantilist institutions of French Canada to their own needs, and the Liberal elite that displaced them after 1837 to do likewise. ${ }^{33}$ Only after a vast inflow of immigrants did Canadian voters begin to reject mercantilist policies, and even then with distinctly mixed feelings. Thus, Porter (1965) argues that Canadians, both English and French, still respected established institutions and hierarchies more than their American cousins in the mid $20^{\text {th }}$ century. All of this is consistent with a slower development of the institutions of liberal capitalism in the framework of La Porta et al. (1997a).

\section{Industrialization}

The last decade of the $19^{\text {th }}$ century and first decade of the $20^{\text {th }}$ century were Canada's high growth period. Understanding how corporate ownership and control, and other institutions, evolved during this period is therefore of special interest, as is the institutional structure developed in the prior two decades.

The high growth period corresponds closely to the governments of Sir Wilfrid Laurier, the first long-serving prime minister unmarred by scandal. Laurier's Liberals took power in 1896, and oversaw a booming economy that lasted until his defeat in 1912. The first Québecois Prime Minister, Laurier grandly proclaimed, "Canada will fill the twentieth century." This seemed not absurd at the time, for Canada's population and industrial production grew at unprecedented (and unsurpassed) rates. A popular diversion of the time was forecasting when Canada's population would exceed that of the United States by extrapolating the two countries' growth rates. Visionary politicians seriously advocated imperialism, envisioning Canada assuming the burden of weary Britain's worldwide Empire. This too seemed not unreasonable, and Laurier was a dedicated imperialist.

The fat Hudson's Bay Company dividends of this era, shown in Figure 1, as well as the more direct measures of growth in Figures 2 and 3, all also attest to the country's prosperity.

Economic expansion paralleled an immigration boom. Under Laurier, Canada's population rose $44 \%$. Western Canada was rapidly populated along the proliferating transcontinental CPR system. All sectors of the economy grew rapidly and simultaneously to accommodate this infrastructure investment, and the millions of new consumers flooding in. The situation thus closely resembles what Murphy et al. (1989) call a big push - rapid development sustained by the simultaneous expansion of many interdependent sectors, so demand for intermediate and final goods grows apace with their supply.

The railway, and the immigrant settler farms springing up around it created an economic low pressure zone. Every sort of new business was needed to supply the railroad, the settlers, and all the other new businesses opening to serve them.

\footnotetext{
${ }^{33}$ Haber (2002) describes a similar preservation of the institutions of 'crony capitalism' by successive new elites in
} Latin America. 
Figure 2. Overall Economy Growth, 1870 to 2000

Population in millions and per capita Gross National Product (GNP) in 1986 Canadian dollars are measured on the left axis. Total GNP in billions of 1986 Canadian dollars is measured on the right axis.

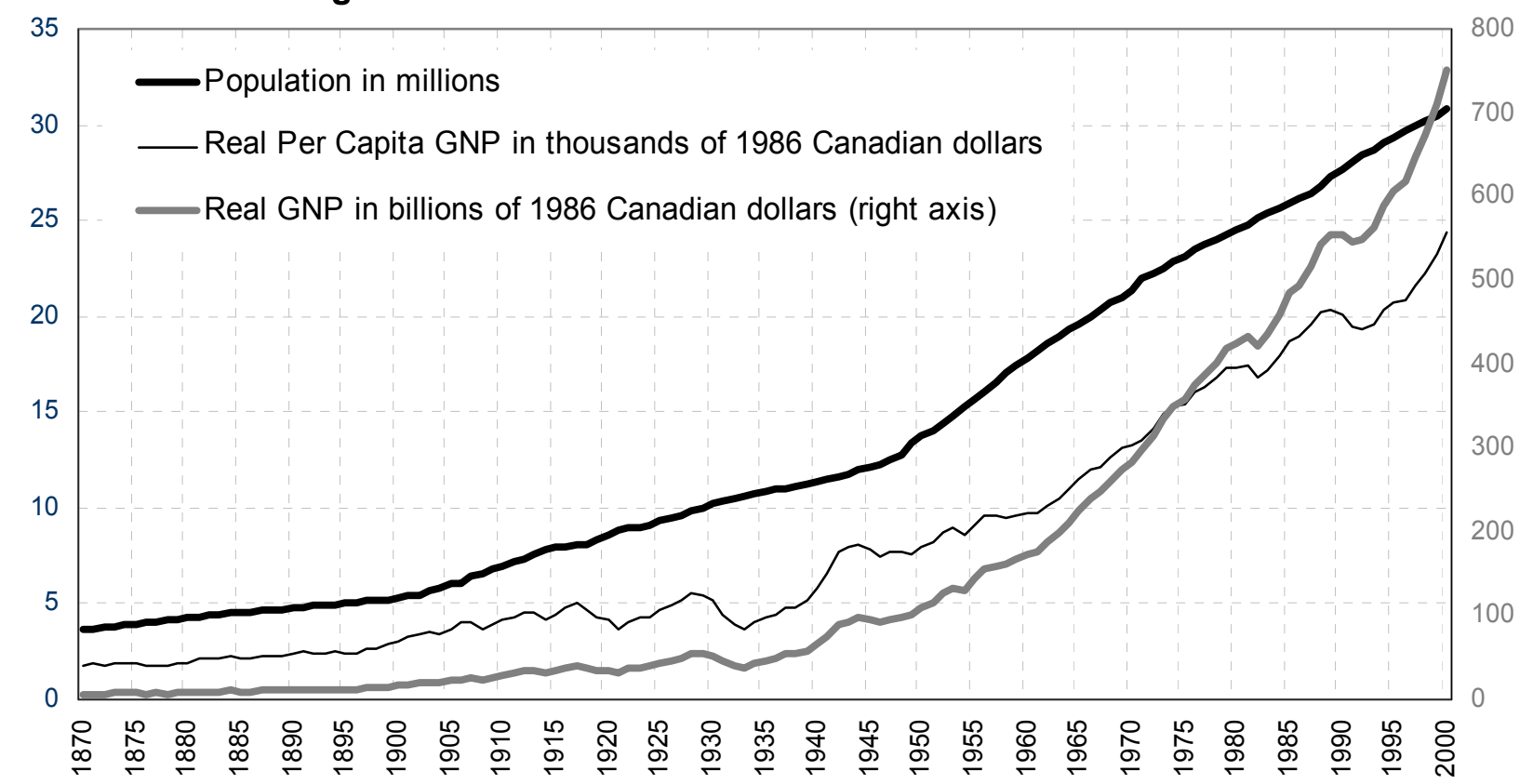

Source: Data up to 1926 are from Urquhart (1993). Later data are from Statistics Canada: Historical Statistics of Canada.

Figure 3. Economic Growth, 1870 to 2000

Annual growth rates in population and per capita GNP in 1986 Canadian dollars.

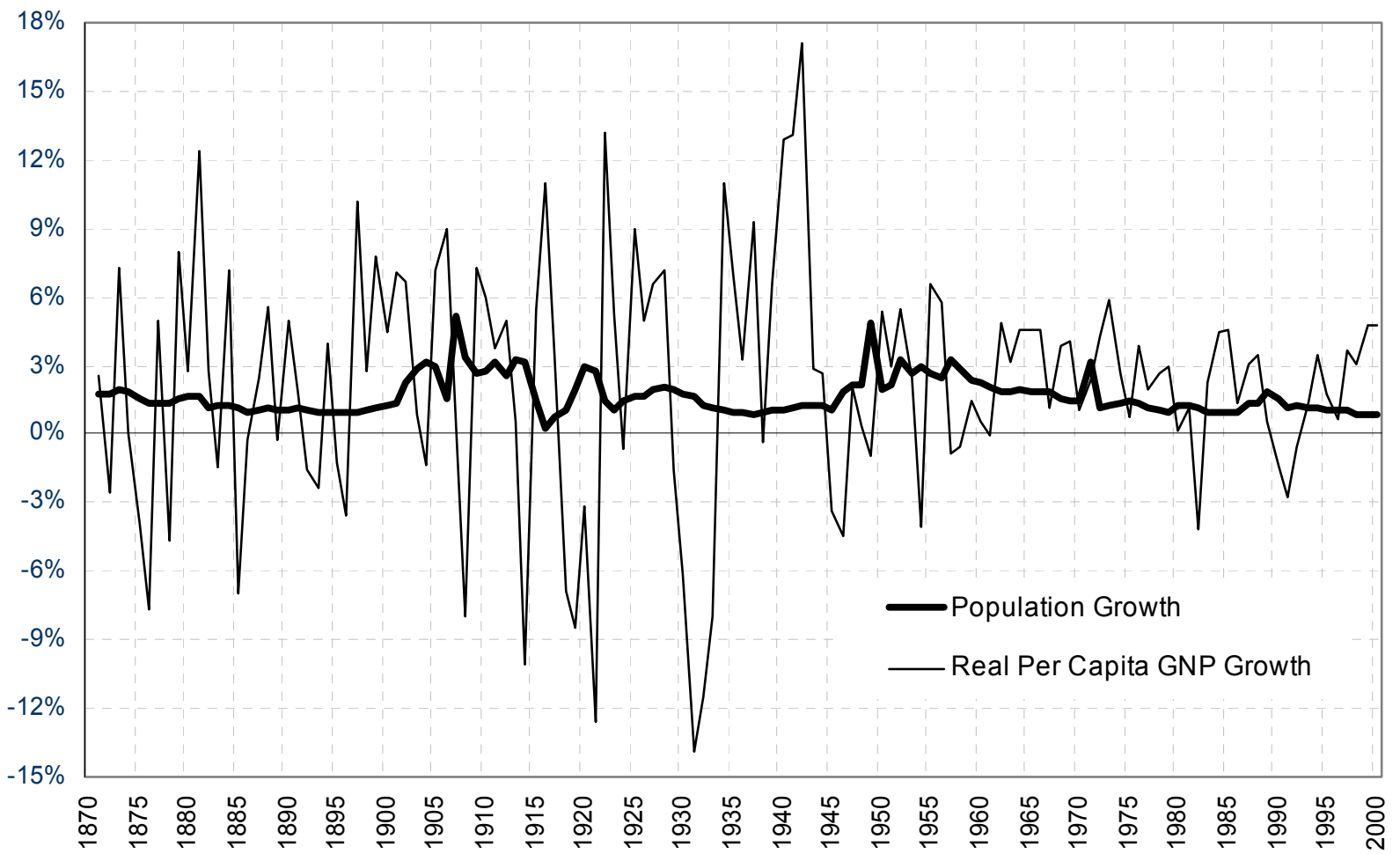

Source: Data up to 1926 are from Urquhart (1993). Later data are from Statistics Canada: Historical Statistics of Canada. 


\section{Bracing for the Big Push}

Although the actual big push occurred when Laurier was Prime Minister, the Tory Prime Minister, John A. MacDonald cleared the way over the previous two decades. He did this by managing unfolding political events to divert ever greater subsidies to the CPR. The successful completion of this transcontinental line created space for immigrants, who raised demand for all manner of goods, which allowed the big push to succeed. The details of this ground clearing are important.

In 1867, Canada's most important business was still the Bay, which still owned Rupertsland most of the northern half of North America. The Chief Factor, George Simpson, ruthlessly exploited Rupertsland from the mid 1820s to the 1860s. The bastard son of a Presbyterian minister, Simpson had a profound suspicion of ethics that compensated for the waning European demand for beaver pelts. Nonetheless, the Bay's directors saw an inevitable decline in both the fur trade and the Bay's dividend in Figure 1. Through two takeovers, the Bay diversified into lumbering, fishing, livestock, coal mining, buffalo wool, and even a colony in Oregon. All failed, and the dividend slid. Ultimately, a new management team concluded that forsaking the fur trade and selling the Bay's vast landholdings was in the best interests of the shareholders. In 1868, the next Chief Factor, Donald Smith, sold Canada all of Rupertsland, including the Manitoba colony. The profit maximization decision of a monopoly resource extraction company thus transformed Canada from a colony of extraction to a colony of settlement.

The big push that followed saw no abatement of corruption. Property rights actually grew more unsettled before they became stronger, and the transcontinental line's construction was rife with political kickbacks and self-dealing. The Bay had never assigned formal land titles to the residents of its Manitoba colony. Sold to Canada with no provision for their property rights, the métis and other settlers rose in rebellion in 1869. The poet and philosopher Louis Riel declared a Republic of Manitoba, and seceded from Canada. ${ }^{34}$ The rebels surrendered in 1870, and President Riel fled. Manitoba rejoined Canada as a province and the rest of Rupertsland became the Northwest Territories. Property rights were formalized and settlers poured in. But MacDonald concluded that Canada needed a transcontinental railroad to exercise sovereignty over this vast region. In 1871, he convinced the British Pacific coast colonies to join Canada as the province of British Columbia by promising them a transcontinental railroad.

Hugh Allan, owner of the Allen Line, founded the Canada Pacific Co. to build the link. The Grand Trunk, fearing competition, lobbied furiously to undermine Allan's company. The Panic of 1873 and subsequent depression - Figure 3 shows a drop in per capita GNP of almost 8\% in 1876 - stalled these plans. The exposure of a huge kickback from Allan to MacDonald brought down the Tory government, prolonging the stall. The new Liberal government of Alexander Mackenzie cautiously raised the tariff and tried to rehabilitate Canadian debt in London. But a series of bank panics and failures continued through the $1870 \mathrm{~s}$.

With no railroad in sight, British Columbia elected a separatist government in 1878. MacDonald recaptured power in 1879 pledging to complete the railroad immediately - as well as raise the tariff and subsidize the Roman Catholic clergy.

The CPR was incorporated in 1881, and its first president, George Stephen, quickly sold his own railways to the CPR. MacDonald provided the CPR a subsidy of millions of acres of former Bay lands. These were assigned to a company controlled by the Bay's Chief Factor, Donald Smith, and Edmund Osler, the owner several other railways the CPR bought. In 1883, Smith joined the CPR board and quickly dominated its management. Thus corruption, or at least self-dealing, was central to the CPR from its inception.

To keep railroad construction teams supplied, existing industrial production expanded rapidly. Land prices soared, new coal and natural gas fields were discovered and developed, and settlers moved farther west onto land claimed by Indians and the Métis descendents of trappers. In 1884, Louis Riel reappeared to declare a Republic in Saskatchewan. MacDonald now had to subsidize accelerated CPR construction to move troops to Saskatchewan. Riel was hanged and no other province has seceded (at writing). The Indian tribes, all repeatedly decimated by disease, and aware of the carnage in the western United States, signed treaties and moved peaceably onto reservations. British concepts of property rights replaced communal tribal claims everywhere else.

\footnotetext{
${ }^{34}$ See Myers (1914) chapter 9 for a detailed description of the conflicting interests behind the rebellion and its suppression.
} 
The CPR finished its transcontinental mainline in 1886, and then diversified into steamships and luxury hotels. It soon displaced the Bay as the dominant business of the land. Presidents of the CPR and Prime Ministers of Canada renegotiated subsidies (upwards, eventually to over 200 million dollars plus land grants) as equals. ${ }^{35}$

Railroads built the greatest fortunes of the 1890s, enriching Richard Angus, Joseph Hickson, George Cox, Duncan MacIntyre, Lord Strathcona and Mount Royal (formerly Donald Smith), Lord Mount Stephen (formerly George Stephen), and William Van Horne. All but Cox and Hickson grew wealthy building or operating the CPR. Hickson grew rich revitalizing the old Grand Trunk, and Cox by reselling the bankrupt Midland Railway to the Grand Trunk. ${ }^{36}$

The stage was now set for 'big push' development, as in Murphy et al. (1989). Large pools of capital stood ready. The CPR, albeit built for political and military reasons, opened vast new territories. Population could grow rapidly, for the Bay no longer blocked settlement. Rather, its Chief Factor was set to make a fortune selling land to immigrants.

All this occurred in an economy still mired in both official and private corruption, surrounded by prohibitive tariffs, and hosting a scandal-plagued financial system.

\section{Corruption and the Big Push}

Official corruption retards economic development - see Mauro (1995) and many others for empirical evidence. Murphy et al. $(1991,1993)$ argue that corruption does this by raising the return to investing in political connections above that to investing in ordinary business projects, like plant and equipment, or research and development. This diverts talented individuals away from careers as engineers, inventors, and entrepreneurs and into more lucrative careers as politicians and bureaucrats.

Canada was clearly an extremely corrupt country, at least by modern standards, when it began industrializing. However, politicians expected, and were expected to become wealthy from public office. Behavior that today would clearly constitute corruption was not only legal, but anticipated.

An 1875 requirement that insurance companies invest domestically repelled foreign insurers and opened the field for a spate of new Canadian insurers. Confederation Life was run by Sir Francis Hincks, then Finance Minister. Prime Minister Mackenzie took charge of North American Life after losing power in 1878. Prime Minister MacDonald served as president of Manufacturer's Life while in office. Sun Life was run by Matthew Gault until MacDonald intervened to oust him. The Bay's Chief Factor, Donald Smith, used his seat in Parliament to promote his steamship and railway investments in Manitoba. ${ }^{37}$

Thus, members of Parliament and provincial politicians, such as Manitoba Premier John Norquay, routinely empowered each other to develop and run coal mines, lumber companies, and land companies. ${ }^{38}$ Robert Dunsmuir, wealthy from his Union and Wellington Colliery, Esquimault and Nanaimo Railway, and especially his land grant from the government at the CPR Pacific terminus, an obscure village called Vancouver, served the people of British Columbia in the provincial legislature. ${ }^{39}$

Municipal politicians also moonlighted as barons of industry. ${ }^{40}$ A good example is George Cox, who ran British America Insurance, Canada Life, the Canadian Bank of Commerce (now CIBC), Central Canada Savings and Loan, Canada Landed \& National Investment Co., Dominion Coal, Dominion Securities, Imperial Life, Manitoba Northwest, National Trust, Toronto Savings and Loan, and Western Insurance. While thus burdened, Cox served the people as the six-term mayor of Peterborough, Ontario.

However, several factors probably eased the drag of corruption on the economy enough for a big push to succeed under Laurier.

First, some corruption worked for the good. Although MacDonald won and retained power through blatantly corrupt elections, took kickbacks from railroad companies, and continually blurred the boundaries between his private and public duties; he pushed through the transcontinental railway. The

\footnotetext{
${ }^{35}$ Myers (1914) chapter 14.

${ }^{36}$ Myers (1914) chapter 14.

${ }^{37}$ Myers (1914) chapter 13.

${ }^{38}$ Myers (1914) chapters 16 and 17.

${ }^{39}$ Myers (1914) chapter 16.

${ }^{40}$ For a detailed list, see Myers (1914) chapter 15.
} 
$\mathrm{CPR}$, though mired in what today we would call corruption, certainly raised the returns to genuine entrepreneurship in numerous other industries, and so shifted talent in that direction.

Second, such corruption grew increasingly unacceptable to the general populace over time. The Yeoman farmers of Ontario found the Family Compact's economic stranglehold maddening enough to rise in rebellion in 1837, and the Liberal rebellions of 1837 brought corruption down a notch. Official failures to honor existing property rights caused first Manitoba and then Saskatchewan to secede. Both rebellions were put down, but both also ratcheted respect for private property rights up a notch. MacDonald, though not jailed for demanding kickbacks from railroads, was forced from office temporarily. Future politicians would have to be more honest, or at least more careful. Ultimately the big push came under Laurier, who gave Canada almost two decades of unprecedentedly honest government, and hence of abnormally low returns to corruption.

Finally, the returns to genuine business entrepreneurship in Canada probably were very high indeed during the big push years. Even given a degree of corruption, genuine entrepreneurship was still a very attractive career. This requires a bit of elaboration.

Counterintuitively, the weakness of certain property rights likely encouraged local entrepreneurs. Before 1872, honoring foreign patents was illegal. This let Canadian entrepreneurs freely use the most up-to-date foreign technology. In response to suggestions by some of Canada's trading partners, MacDonald revised the Patent Act in 1872 to permit the honoring of US patents if the holder had a plant in Canada. This was justified as encouraging foreign investment. Overall, these policies encouraged new high technology industries, including steel casting, cement manufacture, farm machinery, and the like.

Fortuitously, many new technologies fit the Canadian economy well. The countryside was designed for hydroelectric power. One important project, by William Mackenzie, momentarily drawn from his railroads and Latin American investments, was turbines under Niagara Falls and lines to transmit the power to Toronto.

Also tailor-made for Canada, another new technology made paper from wood pulp, rather than rags. Mills could use hydroelectric power to grind low-grade trees into pulp to produce paper. Hector Clergue built such a mill at Sault Ste Marie, and the CPR tycoon Van Horne acquired another by squeezing the entrepreneur John Foreman out of his company, Laurentide Pulp. The first prominent Québecois entrepreneur, Alfred Dubuc, built his Compagnie de Pulpe de Chicoutimi because, as he admitted to his banker, "Je n'ai pas d'argent." 41 Established lumber barons, including matchmakers Eddy and Booth, also diversified into pulp and paper.

This period also saw the beginnings of Canada's minerals industries. Discovering iron ore near his Sault Ste Marie mill, Clergue formed Algoma Steel Co. to mine and refine it and the Algoma Central Railway to ship it out. Samuel Ritchie gambled on the discovery of low-grade copper and nickel ores in Sudbury, and won hugely when the Boer War pushed prices up sharply. A takeover of Ritchie's mining operation and an amalgamation with several other mining and smelting companies organized by Robert Thompson's smelting firm created International Nickel. When formed in 1902, it was the world's largest nickel producer. The CPR also entered the field, forming the Consolidated Mining and Smelting Company of Canada, or Cominco Ltd.

The CPR diversified, in part, because freight rates fell as the Manitoba entrepreneur William Mackenzie and his partner, Donald Mann, strung bits of railroad together to compete with the CPR in its most lucrative runs. This competition ultimately lowered rail shipping costs substantially, providing further scale economies.

Millions of new immigrant farmers were also soon in business. Canada quickly became the world's largest wheat exporter, and Winnipeg the world's largest commodity exchange. Rising farm income created millions of new aspiring middle class consumers. The semi-literate Patrick Burns built a huge beef packing empire based in Calgary.

Selling consumer goods across the much expanded country built more fortunes. The barely literate Irish immigrant, Timothy Eaton, built a nationwide catalogue department store business that bypassed wholesalers and used the railway system to deliver goods either to branch stores or directly to consumers. Replacing the declining staples wholesale businesses, Eaton's and its imitators - Robert

\footnotetext{
${ }^{41}$ Bliss (1986) p. 323.
} 
Simpson and Charles Woodward, and of course the Hudson's Bay Company - would dominate Canadian retailing for the next century.

And new information industries arose as the populace grew more educated and economically active. John Bayne Maclean, a clergyman's son, launched the Canadian Grocer, Canada's first weekly newspaper. He quickly launched a succession of other newspapers: Hardware and Metal, Books and Notions, Dry Goods Review, and Canadian Printer and Publisher. His main surviving ventures are the Financial Post and The Busy Man's Magazine, reticently renamed Maclean's. The Southam family used profits from their Spectator to acquire a steel company, printing plants, and national newspaper chain.

\section{Finance and Growth}

King and Levine (1993) demonstrate a marked correlation between the development of a country's financial system and its economic growth. Canada's financial system under MacDonald consisted of an anemic stock market and banks adhering religiously to the real bills doctrine, lending only for trade credit. Naylor (1975) argues that this adherence had substantially slowed growth by precluding loans for capital. However, by the end of the Laurier years, financial institutions were lending to all manner of businesses and the stock markets had seen two sustained waves of IPOs.

Up to the late $19^{\text {th }}$ century, new ventures were predominantly financed with some mixture of family money, government subsidies, and the retained earnings of existing companies. Both corruption and genuine entrepreneurship had built sizable family fortunes. The largest included Maritimes shipping dynasties, heirs of the Montreal fur traders, and a handful of old Loyalist families. Hugh Allan made another fortune off his vast ranches in Alberta as meat production shifted west. Alexander Tilloch Galt, whose family had helped settle English immigrants in both Upper and Lower Canada in the $19^{\text {th }}$ century by buying land from Loyalists and reselling it to settlers, repeated this model in Alberta with more success than in either previous venture. Canadian lumber barons, such as John Hendry of New Brunswick and the Maclaren family of Québec, began major operations in the new provinces. The tycoons who built, supplied, and operated the CPR and other railroads also acquired vast wealth. And wealth from past government connections created other lasting family fortunes. These assemblages of capital, and their owners' desire to diversify, helped launch new industrial ventures across Canada.

Laurier had originally criticized MacDonald's CPR subsidies, and eschewed subsidizing industry until late in his final term. But provincial and municipal governments had no such compunctions. A government-subsidized railway into Northern Ontario in 1902 brought a fabulous return, as minerals were discovered all around it, and is still used to justify publicly-financed development schemes. Gilbert Labline and Noah Timmins developed Hollinger Mines. J. P. Bicksell took over Porcupine Mines after its original owners were imprisoned. These firms, and the new Dome Mines, fueled a second wave of penny mining stock issues. Over five hundred new mining companies were listed in Toronto to meet investor demand at the end of the new century's first decade.

The mining business built more fortunes when gold was discovered, first in British Columbia in the early 1890 s and then in the Yukon in 1898. A booming industry of fraudulent penny stock IPOs sprang up in Toronto, fleecing investors from across Canada and around the world. Two additional exchanges were formed in Toronto to handle the boom. ${ }^{42}$ Despite the endemic fraud, Canada now had stock markets that attracted capital from all over the world.

Canada's securities markets and financial system had now developed to the point that growth through stock and debt financed mergers and acquisitions became possible. Thus, George Cox and his partner, the former Prime Minister MacKenzie Bowell, who ruled briefly between MacDonald and Laurier, built National Investment Co. through an M\&A program. In fact, the early 1890 s constituted Canada's first M\&A wave. Figure 4 shows M\&A activity from the first Canadian records to the present, and reveals a distinct surge in this period.

Virtually all of the new companies had controlling shareholders, so a takeover or merger usually required buying a private family company or buying a control block of a traded company from an existing dominant shareholder. Also, much M\&A activity involved buying out small-scale family controlled firms, and merging them into growing national companies.

\footnotetext{
${ }^{42}$ See Armstrong (1997) for details.
} 
Figure 4. Merger and Acquisition Activity, 1885 to 2000

Number of mergers and acquisitions per million 1986 Canadian dollars of GNP.

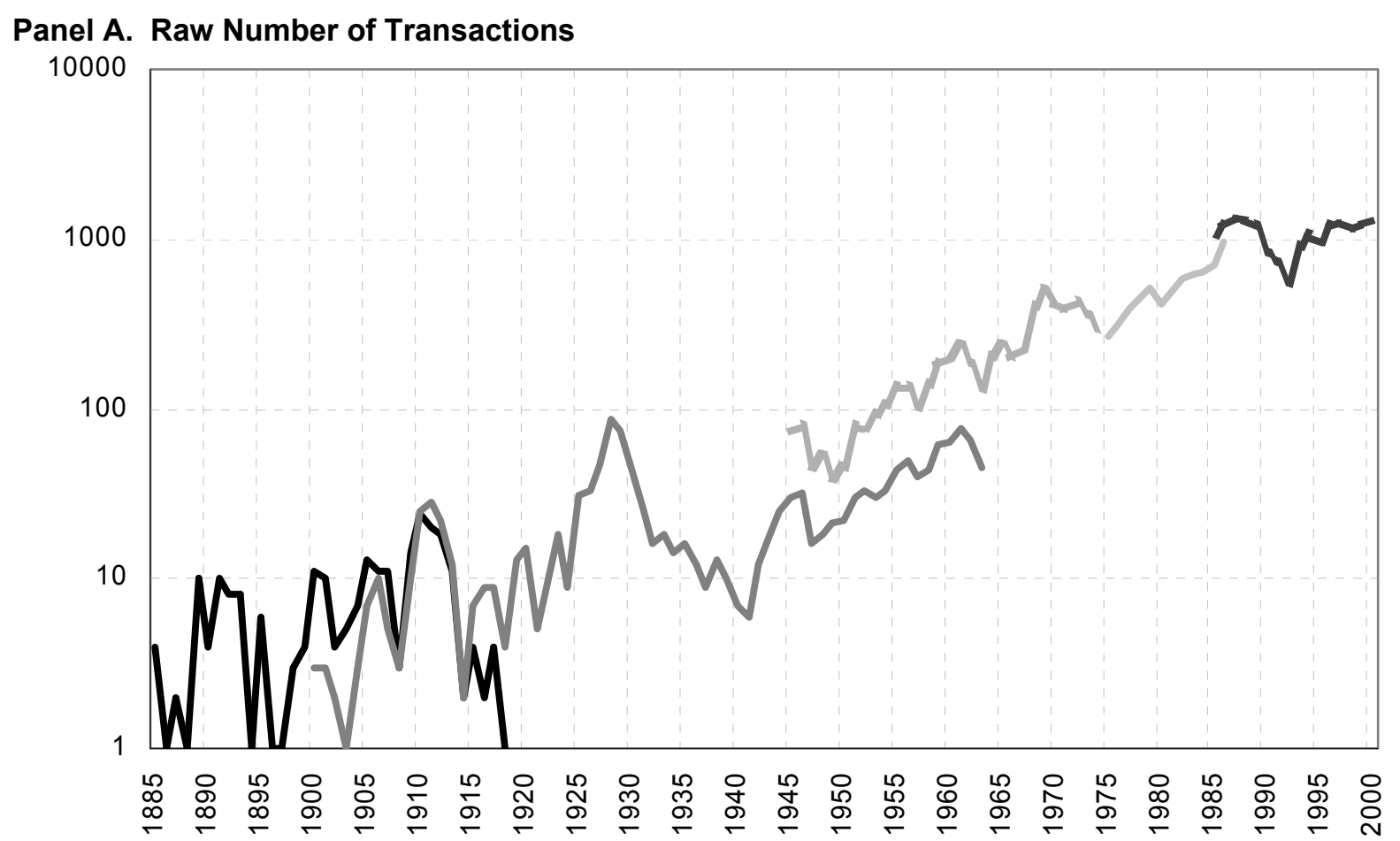

Panel B. M\&A Transactions per Dollar of Real 1986 Gross National Product

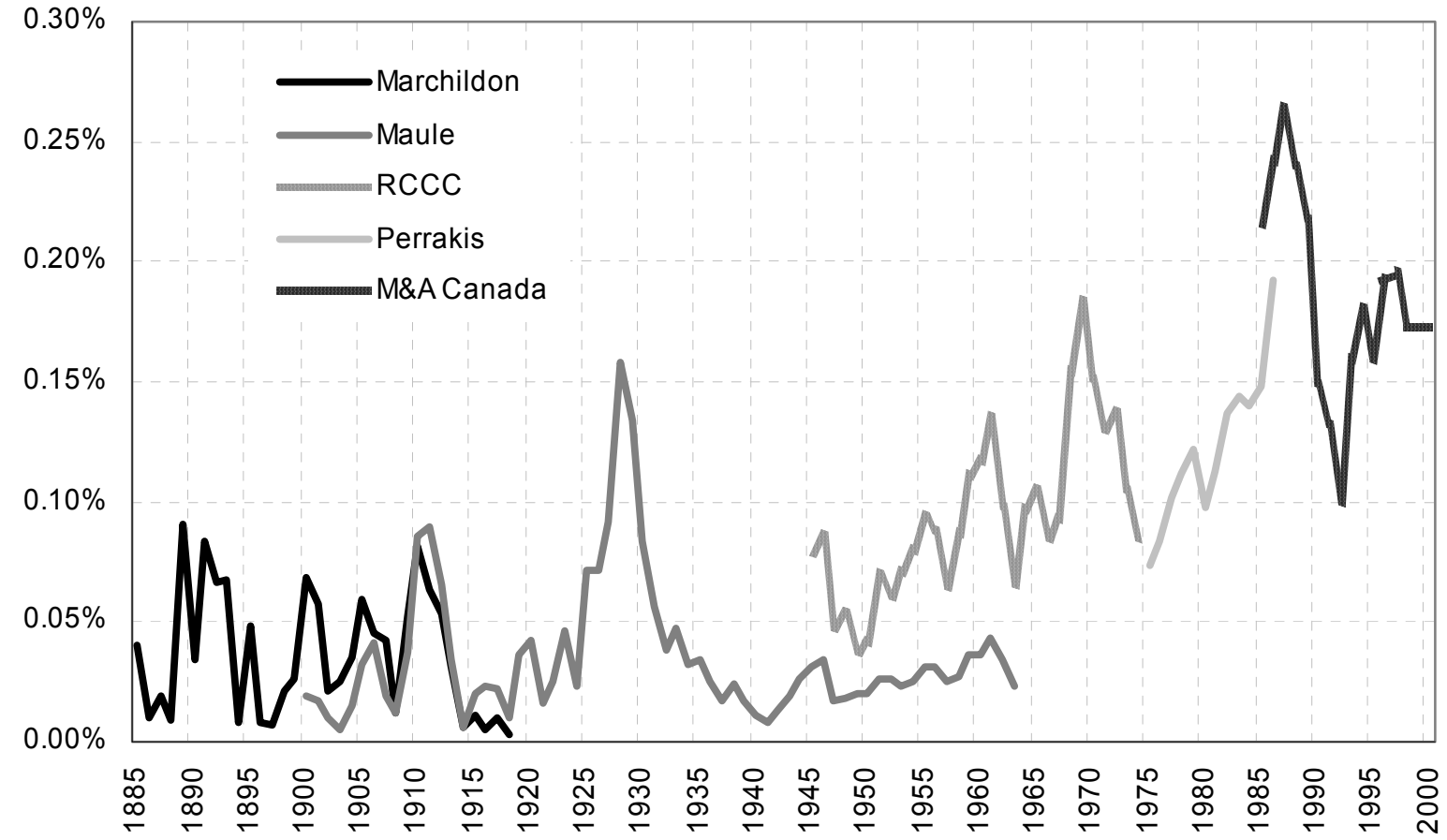

Data for 1885-1918 are from Marchildon (1990), data for 1900-1963 are from Maule (1966), data for 1970-1986 are from Globerman (1977, Royal Commission on Corporate Concentration), and data for 1985-2000 are from the Directory of M\&A in Canada. Because discrepancies exist across different sources, we apply linear transformations to each overlapping period and move different series up or down to generate a single time series. 
Max Aitken's Montréal Trust and Monty Horne-Payne's British Empire Trust issued bonds in London to financing Canadian M\&A. Other M\&A entrepreneurs used acquirer company stock to buy targets. A domestic securities industry grew fat off the proceeds of public issues as domestic demand for investments rose.

Venerable family firms seemed in decline. George Cox, despite the obvious incompetence of all his sons, entertained visions of a continuing the Cox dynasty. In 1905, James Henry Gundy and George Herbert Wood quit Cox's Dominion Securities to form Wood Gundy Ltd., which quickly grew to dominate the securities industry. Banks and insurance companies, as well as trust companies and the new securities firms, directed Canadian savings into industrial ventures via bonds, preferred stock, and common stock.

These developments permitted a second wave of mergers and acquisitions just before the First World War. By raising cash through bond issues via their securities houses, raiders could finance corporate takeovers. By swapping shares, they could undertake mergers. Figure 4 shows a second burst of M\&A activity in the early $20^{\text {th }}$ century.

In 1899, Henry Melville Whitney issued shares to consolidate several collieries into Dominion Coal, and then to diversify into steelmaking with Dominion Coal and Steel. The Cox family responded by setting up the country's first pyramidal group, with public shareholders holding minority interests in Crow's Nest Pass Coal, Canada Cycle and Motor Co., and a host of other firms. Panics in 1903 and 1907 soured many of the old families on equity holdings, but public demand continued.

\section{Openness}

That trade openness encourages development is well established. See e.g. Bhagwatti (1998). The role of financial openness is more controversial. Bhagwatti cautions that financial openness leads to financial instability, and that proponents of globalization should be content with trade openness. However, Henry (2000, 2000a) shows that modern day emerging economies experience investment booms upon opening their financial markets and institutions to the global economy.

To subsidize the CPR, MacDonald needed more government revenues. The main source of public funds at this time was the tariff. MacDonald's Tories therefore proclaimed the National Policy tariffs ultimately averaging 35\% across the board, ostensibly to promote rapid industrialization by restricting imports. The National Policy is thus a genuinely classical example of import substitution. It remained in effect, in one form or another, until the post World War II trade liberalizations. Canada's success under this regime is probably the most important argument advanced by later proponents of import substitutions, such as Prebisch (1971).

However, Canada had no major restrictions on capital inflows or outflows during its high growth period, for the country was on the gold standard. Despite the rapid financial development within Canada, the big push leaned heavily on foreign capital. More foreign investment flowed into Canada per year in absolute terms during the Laurier boom than into the United States. This capital, mainly from Britain, but to a lesser extend from the United States, funded waves of startups, expansions, and corporate takeovers that reshaped the economy utterly.

Again, the groundwork for this vast capital inflow lay, to some extent, in the corrupt institutions of the previous two decades. MacDonald's revised Patent Act of 1872 protected US U.S. patent holders with operations in Canada; and his National Policy blocked US exports. The result was a sustained wave of FDI, as US firms set up shop to protect their patents and then expanded to serve the domestic market. For example, Alexander Graham Bell entrusted his father, Alexander Melville Bell, to set up a Canadian telephone company - American Bell of Boston held Bell's patent from the 1880s on. Thus trade barriers and selectively weak property rights actually stimulated capital inflow.

Subsidies to foreign capital also played a role. Canadian municipalities everywhere, eager to attract such high tech ventures, offered increasingly competitive "bonuses" - up front cash subsidies - to manufacturers. A multitude of bidding wars, often financed with municipal bonds, erupted across the country, with The Monetary Times reporting in 1895 that 
American firms of every description 'seeking a new site' or 'wishing to extend their business by establishing a Canadian branch' have only to make public their designs and be inundated by letters from Canadian municipal authorities. ${ }^{44}$

Despite their success in generating foreign capital and branch plants, the overall efficacy of these industrial policies as a development strategy remains a topic of debate. For example, Naylor (1975) argues that their side effect was Canada's marginal position in the wave of technological innovation in the 1890s and early 1900s. ${ }^{45}$ Bliss (1986) argues that the National Policy "created distorted hot-house growth in manufacturing that had serious, often harmful consequences," and cites a vast overcapacity in chic high-technology industries like textiles and steelmaking. Irwin (2002) argues that rapid growth in Argentina and Canada, two high-tariff, high-growth outliers in the late $19^{\text {th }}$ century, depended on commodity exports, not industrialization through import substitution. He argues that the tariff was a revenue source, but never a spur to industrialization.

Another distortion was smuggling, which became a major industry. Although this had some beneficial results, such as fueling the growth of Fort Whoop-Up in the part of the Northwest Territories that would become Alberta, its effects were probably mainly negative.

The National Policy also fostered inefficient and high cost production. Few Canadian firms were capable of exporting. Notable exceptions were the farm machinery firms of Hart Massey and Alanson Harris, both based on Canadian patents and American prototypes. Both prospered as Canadian farming modernized. By 1891, when the two great family firms merged, both had robust export businesses in Argentina, Australia, and Great Britain. Administrative technicalities initially limited their US exports.

But, reciprocal trade barriers stymied creative entrepreneurs. Thus, J.L. Kraft moved his cheese business from Ontario to Chicago in 1905. Over the longer term, the public's identification of tariffs with Canadian nationalism, fueled by the MacDonald Tories and later picked up repeatedly by populists and socialists, would emotionally charge trade and foreign investment policy discussions for a century.

As the big push ended, Canada became a capital and technology exporter. Fresh from building the now world famous Canadian Pacific Railroad, the longest in the world, other railroad barons looked abroad, setting up railways in Brazil, Cuba, Guatemala, Mexico, Spain, and the West Indies. Once established in those countries, they moved on to trolley systems, electric power and light systems, and sundry other enterprises. Canadian banks followed into these new markets. The old Cox group, now ably managed by the railroad man Mackenzie and advised by the legal virtuoso Zebulon Lash, also rapidly expanded into Latin America, Spain, and the Caribbean. In 1912, Mackenzie and his chief engineer, F.S. Pearson, combined these holdings into Brazilian Traction, also called o pulve Canadenses (the Canadian octopus). The Mackenzie family still controls one of Mexico's main pyramidal corporate groups.

\section{Initial Corporate Ownership Structures}

As the stock market deepened, widely held industrial firms also appeared. The Hudson's Bay Company generally had no single dominant shareholder, though its Chief Factor often seemed to rule the company and its shares did not trade on exchange. But Canada now had numerous small, widely held mining companies and two widely held giants. Canadian Pacific was widely held from its inception; and by 1900, Bell Canada too was widely held.

However, many large Canadian firms now belonged to pyramidal corporate groups - structures in which a family or closely held apex firm controls other listed firms, each of which control yet other listed firms, and do on. The first such group, that of the Cox family, established in 1899, served as a model. Still, Canadian pyramidal groups were usually not terribly complicated, at least relative to their modern descendents. Most had only a few tiers and a handful of firms. The economic motivations of their builders are also fairly straightforward.

Prior to the big push period, and early into it, old money families and railroad tycoons diversified their wealth by venturing into different industries. As the stock market developed, and public shareholders became a significant source of capital, selling minority interests in these ventures to small investors became increasingly common. Listing its controlled subsidiaries lets a wealthy family leverage

\footnotetext{
${ }^{44}$ Quoted by Bliss (1986) p. 304.

${ }^{45}$ Naylor (1975), Vol. II p. 47.
} 
their retained earnings into control over much larger pools of capital than their own wealth, yet retain complete control. It also let them diversify more extensively while operating on a larger scale in each industry. ${ }^{46}$ Thus, began the first corporate groups.

Larger corporate groups were often the result of takeover waves. From 1909 until 1912, when the economy abruptly slowed, 275 of Canada's largest firms coalesced into 58 in half a billion dollars worth of M\&A transactions. The most active corporate acquisitor of this period was Max Aitken, who assembled Canada's largest pyramidal group. The son of a Presbyterian minister, he rose through the ranks of Royal Securities, ultimately running the firm for its controlling shareholder, John Stairs, heir to the old Nova Scotia merchant family. In 1906, he used his earnings to buy Montréal Trust, and then used that firm to take over Royal Securities. Aitken issued debt in London on a huge scale and used the proceeds to buy steel mills, cement companies, power companies, and other firms all over Canada. In this way, he built the Steel Company of Canada from Montréal Rolling Mills, Hamilton Steel and Iron, Canada Screw, Canada Bolt and many other smaller firms. Aitken also formed Canada Cement out of twelve of the country's thirteen Portland cement makers. At the end of the big push years, Aitken, always a passionate imperialist, bought the title Lord Beaverbrook and retired to London.

Larger corporate corporations and groups also resulted from financial distress. The National Policy produced enormous overcapacity in stylish industries, with many plants run by certifiably unskilled managers. Many of these listed to raise capital, but their on-going overcapacity problems depressed their share prices, inviting the attention of corporate raiders. Thus, A. F. Gault amalgamated about half of the country's cotton mills into Dominion Cotton Mills by 1890, and David Morrice amalgamated most of the rest into Canadian Colored Cotton by 1892. After fairly overtly fixing prices for many years, the two eventually merged into Dominion Textile in 1905.

Acquirers of this era often bought out target controlling shareholders with minority blocks of stock in their other controlled companies. The target insiders who received these shares would sell out to diversify. The result was more complicated structures of less narrowly held listed companies controlling other listed companies. Although Aitken had access to Lon don capital, other Canadian acquirers used the retained earnings of one firm to take over another. Obviously, retained earnings go farther if minimal control blocks are acquired, leaving the target listed after its successful takeover.

It is in this period that we can first construct a broad, though approximate, cross-sectional representation of the ownership structures of large Canadian companies. Figure 5 classifies the top sixtysix firms by ownership structure in 1902, mid-way through the big push, and the top one hundred in 1910 - near the height of the boom.

It shows that four widely held firms account for forty-six percent of large corporate sector assets in 1910, but that this fell to twenty-nine percent by 1910. In both years, the bulk of these assets belong to two widely held firms - Bell Canada and the CPR. The Bell family had sold out prior to this, and the CPR was widely held from its inception. By 1910, the greatest part of the corporate sector, forty percent by assets and forty-five percent of firms, belonged to pyramids controlled by wealthy individuals or families. A substantial number of smaller firms are independent corporations controlled by a family or individual. About one fifth of the corporate sector is foreign controlled, primarily by Britons. We are unable to ascertain the ownership of many firms in these early years. We suspect that most of these are indirectly controlled by wealthy families.

\section{The Evolution of Corporate Ownership}

We replicate Figure 5 for subsequent time periods - every ten years until 1960, and roughly every five years thereafter. We occasionally substitute an adjacent year because of missing data. The main problem is that we do not have Statistics Canada Directory of Inter-corporate Ownership date for every year. These results are graphed in Figure 6.

First, firms whose control is unclear fall off quickly. From 1920 on, the fraction of assets belonging to such firms is near negligible, and the fraction of such firms can be ignored from 1930 on.

\footnotetext{
${ }^{46}$ See Alemida and Wolfenzon (2003) for a formal model.
} 
Figure 5. The Control of Large Firms in the Early $20^{\text {th }}$ Century

The importance of different categories of controlling shareholders in the top 100 firms in 1910 and the top 66 firms in 1902, weighted by total assets and by number of firms.

1902

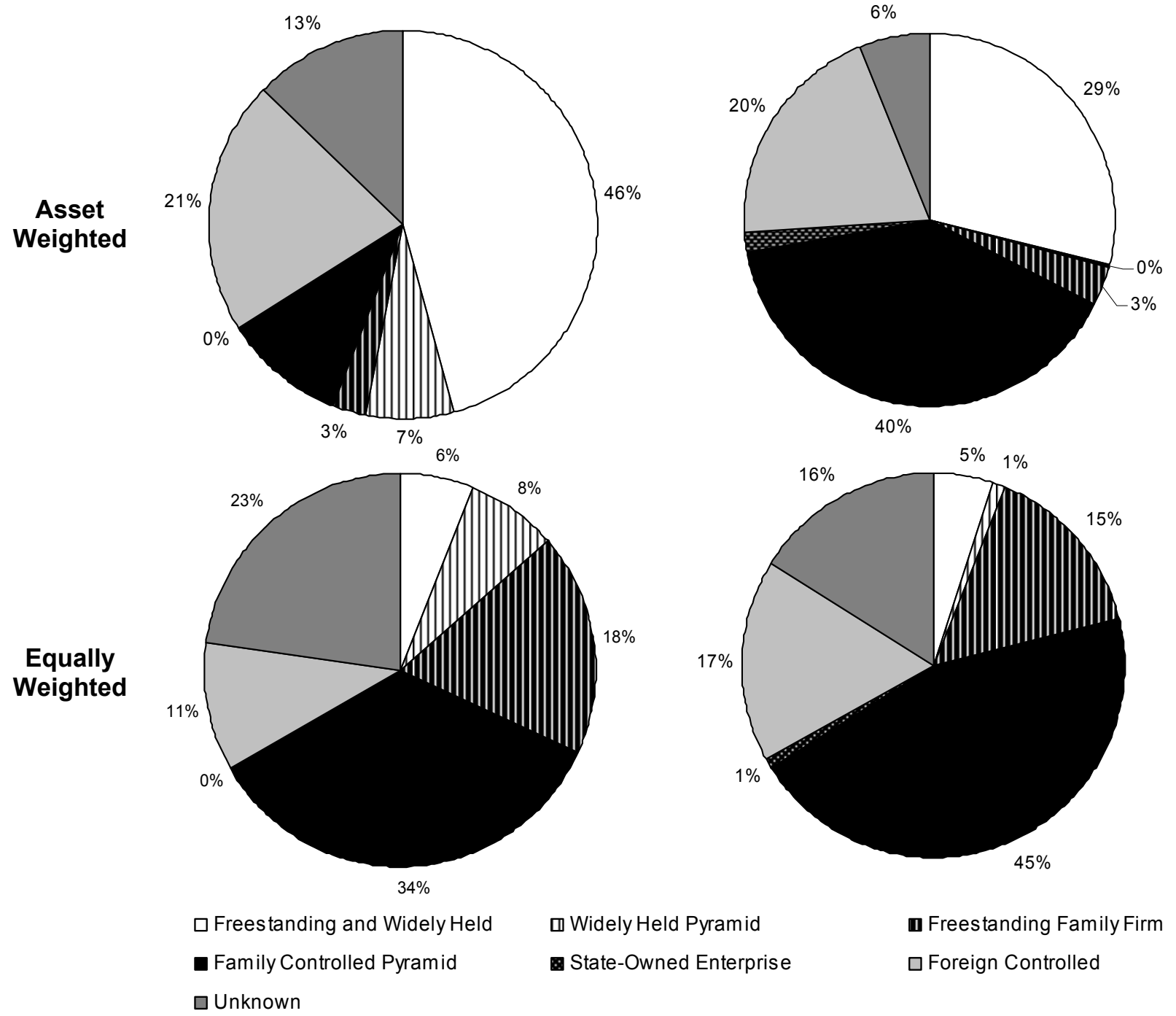

Note: Financial sector firms are excluded. Assets data are from annual reports. Control is assigned using information in annual reports, corporate histories and general histories of Canadian business. 
Figure 6. The Changing Control of Large Firms through the $20^{\text {th }}$ Century The importance of different categories of controlling shareholders in the top 100 firms from 1902 to 1998, weighted by total assets and by number of firms.

Panel A. Asset Weighted

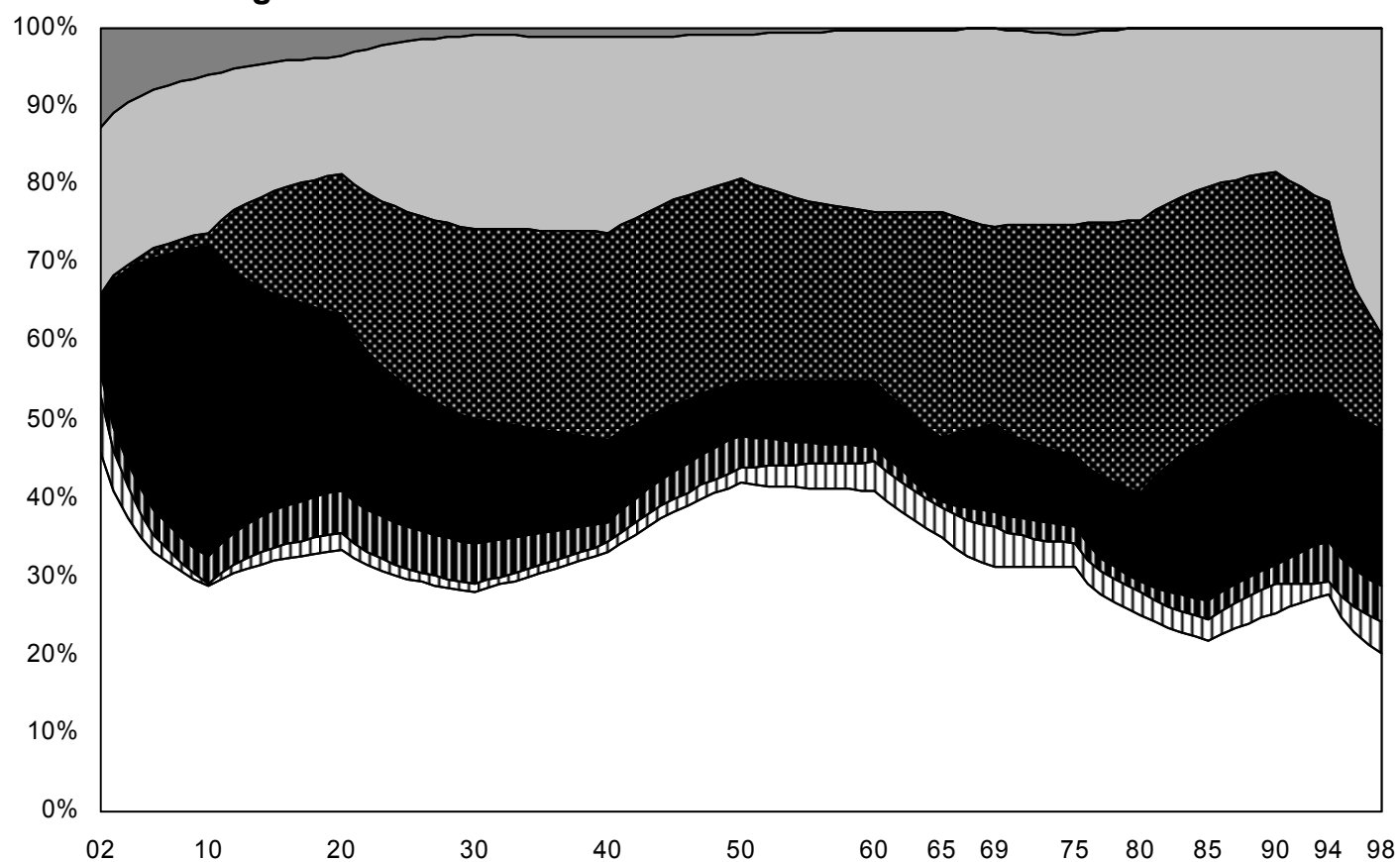

Panel B. Equally Weighted

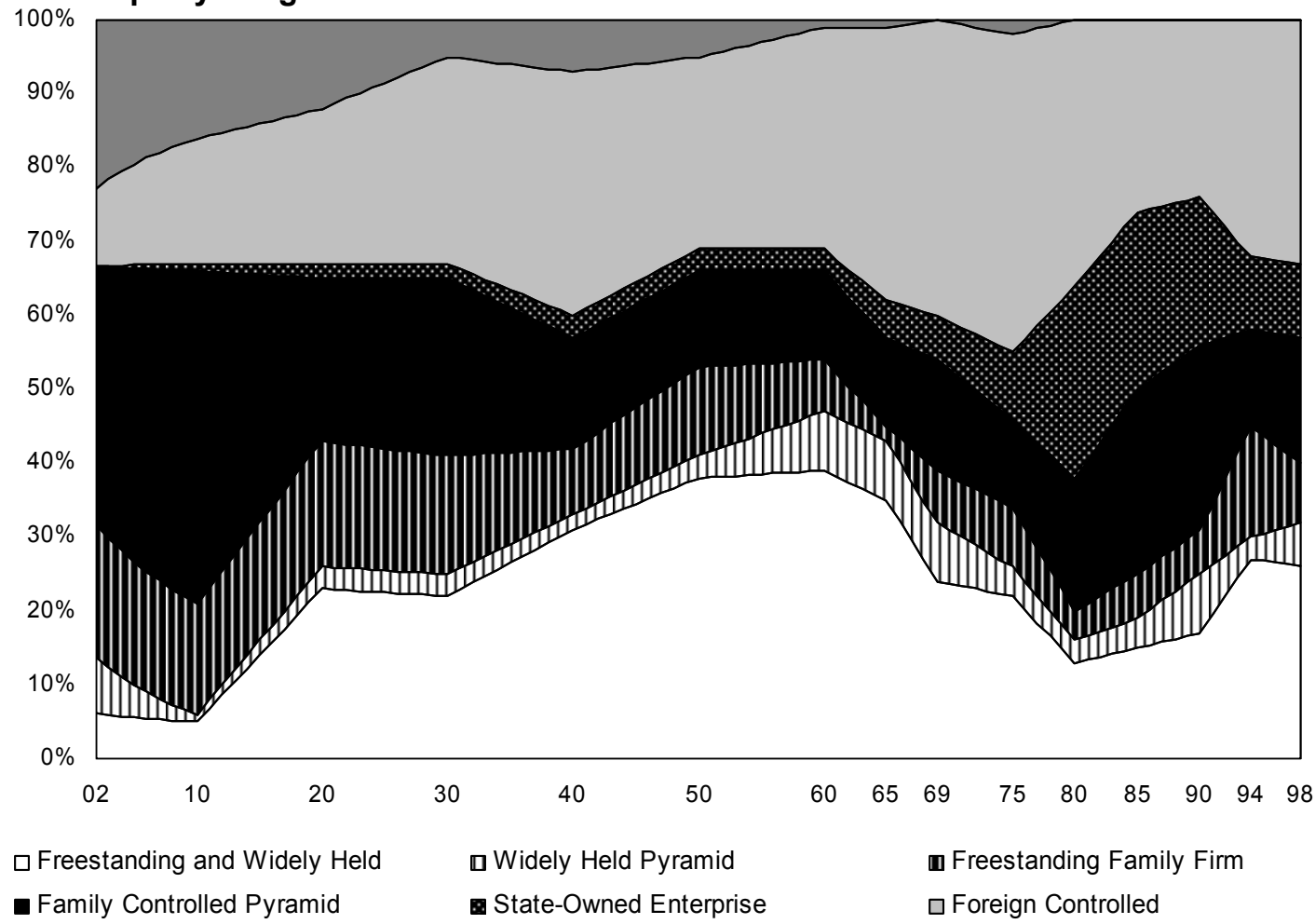

- Family Controlled Pyramid

State-Owned Enterprise

$\square$ Foreign Controlled

口Unknown

Sources: Past issues of Statistics Canada's Directory of Inter-Corporate Ownership, the Financial Post, Canadian Annual Financial Review and Financial Post Corporate Securities; supplemented by Baskerville and Taylor (1994), Bliss (1986), Francis 91988), Myers (1914), Naylor (1975), and individual corporate histories. 


\section{Figure 7. The Changing Control of Domestic Private-Sector Firms}

The importance of different categories of controlling shareholders in the top 100 firms from 1902 to 1998 , weighted by total assets and by number of firms. State-owned enterprises, multinational subsidiaries, and firms whose control is unclear are excluded.

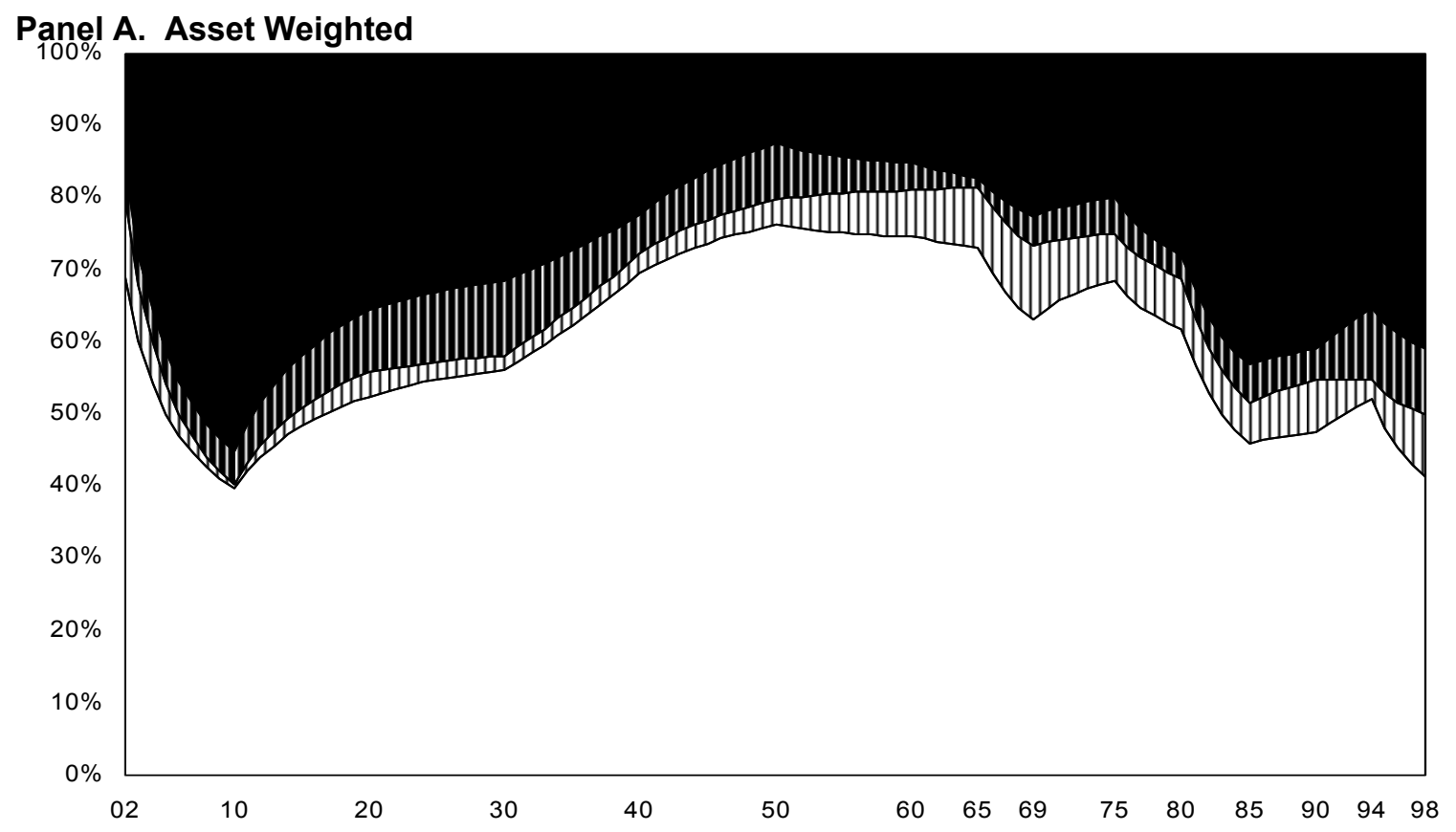

Panel B. Equally Weighted

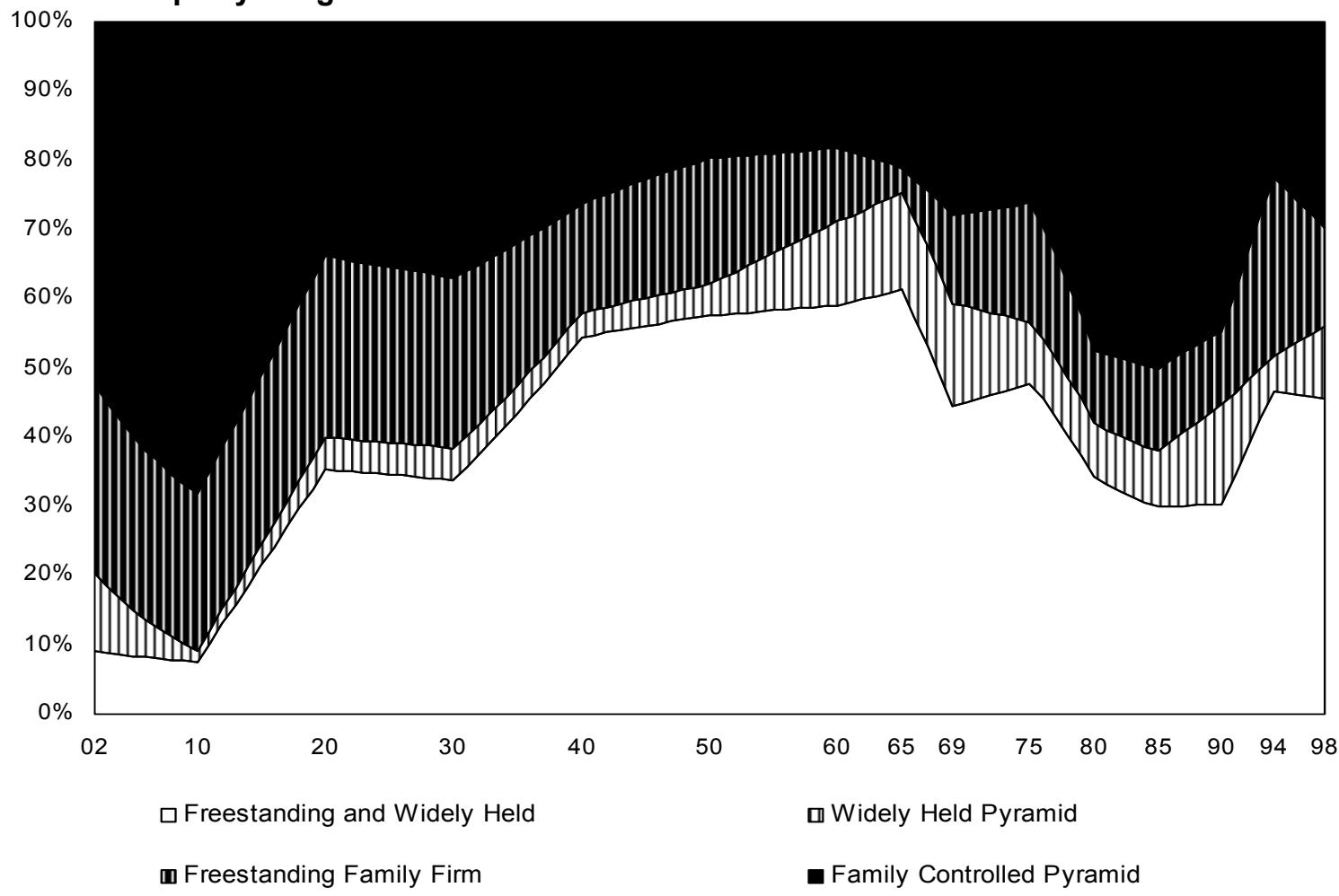

Sources: Past issues of Statistics Canada's Directory of Inter-Corporate Ownership, the Financial Post, Canadian Annual Financial Review and Financial Post Corporate Securities; supplemented by Baskerville and Taylor (1994), Bliss (1986), Francis (1988), Myers (1914), Naylor (1975), and individual corporate histories. 
State control of corporate assets starts at the First World War, grows through the 1990s, and then abruptly falls off, reflecting the privatizations of Air Canada, Canadian National Railways, PetroCanada, and other state-owned enterprises by the Mulroney Tories. Note that the number of state-controlled enterprises rose sharply in the 1970s, reflecting the more socialist policies of the Trudeau liberal governments and their nationalizations, and then falls back in the 1990s as the privatizations go ahead.

Multinational firms have always been important in Canada. In 1902, foreigners controlled about ten percent of the country's large firms, amounting to about twenty percent of corporate assets. Both figures grew to about thirty percent by the 1930s, and fluctuate around that figure for the remained of the century. Foreign control peaks, in terms of number of firms, in the 1970s. This provided the Trudeau Liberals political justification to nationalize numerous companies, as this would keep them out of foreign control. The sharp rise in foreign control in 1998 is due to a few high profile transactions - the takeover of Labatt's Breweries by the Belgian firm Interbrew and the United States firm Verizon's acquisition of a control block in Telus. The nationality of the typical foreign owner also changed. At the beginning of the century, foreign owners were usually British. By the century's end, American owners predominated.

Freestanding widely held firms become more common as the century progresses until the mid 1960s. Thereafter, widely held firms become steadily rarer and account for a diminishing fraction of corporate assets. This pattern is more evident if we drop firms whose controlling shareholder is unknown, foreign controlled firms, and state owned enterprises. Figure 7 replicates Figure 6, dropping these.

The importance of family controlled pyramidal groups, including those controlled by single wealthy individuals, follows precisely the opposite pattern. Family controlled pyramids are commonplace at the beginning of the century, recede markedly by mid-century, and then resurge at the century's end.

This pattern requires explanation. We first provide more details about the rise and fall of different family and widely held firms over a century of business cycles. We then consider various reasons why ownership structures might change over time. Since institutional changes and business cycle conditions often correspond to political events, we refer to periods by the name of the current prime minister. Table 1 lists the terms of office of twentieth century Canadian governments.

\section{Table 1. Canadian Prime Ministers and Governments of the Twentieth Century}

\begin{tabular}{|c|c|c|c|}
\hline Prime Minister & Party & Elected & Resigned \\
\hline Martin, Paul Edgar Philippe & Liberal & December 12, 2003 & \\
\hline Chrétien, Jean Joseph Jacques & Liberal & November 4, 1993 & December 11, 2003 \\
\hline Campbell, A. Kim & Progressive Conservative & June 25, 1993 & November 3, 1993 \\
\hline Mulroney, Martin Brian & Progressive Conservative & September 17, 1984 & June 24, 1993 \\
\hline Turner, John Napier & Liberal & June 30, 1984 & September 16, 1984 \\
\hline Trudeau, Pierre Elliott & Liberal & March 3, 1980 & June 29, 1984 \\
\hline Clark, Charles Joseph (Joe) & Progressive Conservative & June 4, 1979 & March 2, 1980 \\
\hline Trudeau, Pierre Elliott & Liberal & April 20, 1968 & June 3, 1979 \\
\hline Pearson, Lester Bowles & Liberal & April 22, 1963 & April 19, 1968 \\
\hline Diefenbaker, John George & Progressive Conservative & June 21, 1957 & April 21, 1963 \\
\hline St. Laurent, Louis Stephen & Liberal & November 15, 1948 & June 20, 1957 \\
\hline King, William Lyon Mackenzie & Liberal & October 23, 1935 & November 14, 1948 \\
\hline Bennett, Richard Bedford & Conservative & August 7, 1930 & October 22, 1935 \\
\hline King, William Lyon Mackenzie & Liberal & September 25, 1926 & August 6, 1930 \\
\hline Meighen, Arthur & Conservative & June 29,1926 & September 24, 1926 \\
\hline King, William Lyon Mackenzie & Liberal & December 29, 1921 & June 28, 1926 \\
\hline Meighen, Arthur & $\begin{array}{l}\text { National Liberal and } \\
\text { Conservative Party }\end{array}$ & July 10, 1920 & December 28, 1921 \\
\hline Borden, Robert Laird & Unionist & October 12, 1917 & July 9,1920 \\
\hline Borden, Robert Laird & Conservative & October 10, 1911 & October 11, 1917 \\
\hline Laurier, Wilfrid & Liberal & November 7, 1896 & October 6, 1911 \\
\hline
\end{tabular}




\section{Ownership Structure Changes over a Century of Business Cycle ${ }^{47}$}

The merger waves in Figure 4 each correspond to abrupt changes in ownership structures. The main merger waves are: the decades surrounding the beginning of the $20^{\text {th }}$ century, the late $1920 \mathrm{~s}$, early $1960 \mathrm{~s}$, late 1960s, late 1980s, and late 1990s. Figure 3 shows that each was also a business cycle peak. Before considering explicit hypotheses about why ownership structures changed as they did, we provide some background details about conditions over the decades and the associated changes in corporate ownership.

The first merger wave was actually a prolonged period of intermittently high takeover activity spanning the Laurier boom - from the mid 1890s to 1911. Under Laurier's Liberals, new technology and British capital financed waves of takeovers in steel, cement, and other (then) cutting edge industries. Figure 5 shows that these transactions markedly increased in the importance of pyramidal groups - new ones, like the Aitkin group, and pyramids built on old family money, like that of the Coxes.

The subsequent slower growth period, from 1913 though the mid 1920s, saw a decline in the importance of family pyramids. As Figure 6 shows, part of this corresponds to an upswing in state-owned enterprises. Ontario businessmen lobbied successfully for a state-owned power company, now called Hydro One, to provide subsidized electricity. Laurier, previously opposed to all business subsidies, grew pragmatic and agreed to subsidize the old Grand Trunk Railway to build second transcontinental line. William Mackenzie, with Cox money and subsidies from Manitoba, undertook a third. His Tory successor, Prime Minister Borden, poured in more subsidies, and by 1915 the National Transcontinental Grand Trunk Pacific and Canadian Northern were complete. Both were soon hopelessly insolvent, but "too big to fail". After a series of bailouts, Borden bought both in 1917 to form the state-owned Canadian National Railway (CNR).

By the mid 1920s, conditions slowly improved, and new business opportunities emerged. The most significant was Prohibition in the United States, enacted in 1919, which outlawed the manufacture, sale, or transport of alcohol, but permitted its consumption. Sam Bronfman, a Saskatchewan innkeeper, set up a mail order liquor business for thirsty Americans. In a few years, he owned a chain of distilleries along the United States border. Bronfman used his newfound wealth to build a new pyramidal group, and was soon the most powerful tycoon in Canada.

Takeovers in the late 1920s boom, like the Laurier years, built new pyramidal groups. Max Aitkin had retired to London as Lord Beaverbrook, and his former associates took control of his various companies. One of the most successful, Isaac Walton Killam, built the Killam group. Nesbitt, Thompson organized the publicly traded Power Corporation to hold utilities in a pyramidal group. Other major new groups were Canadian Pulp and Power Investments and Hydro-Electric Bond and Share Corp. A very important pyramid builders of this period was the twice Prime Minister Arthur Meighen, who issued debt to acquire control blocks for his Canadian General Investment Trust group.

But despite these new groups, the late 1920s boom, unlike the Laurier years, saw a net erosion of pyramids. The 1920 s boom, like the Laurier years, created new high technology firms - this time in industries like automobiles, airplanes, metallurgy, motion pictures, office automation, and paper making. But now, many were stock financed and widely held early on. Most disappeared in mergers, also financed with stock, eroding control blocks in the acquirer firms.

A global boom favored Canada, fueling demand for paper and minerals. MacMillan, founded by a forestry student who stayed in British Columbia after a summer job, soon dominated forestry. International Nickel developed new alloys that locked in its global dominance. Numerous other mining and minerals refining companies sprouted up. Thus, more new widely held firms joined the ranks of the top corporations.

The Great Depression hit Canada hard in the 1930s. Deflation reduced the cost of living by over $20 \%$ from 1929 to 1933, but wages fell much less. This, and moribund demand, depressed most industries - automobiles, base metals, oil, railroads, pulp and paper, and steel collapsed. Many old family firms failed in the 1930s, their assets bought up by others with money.

\footnotetext{
${ }^{47}$ What follows is drawn from Bliss (1986), Francis (1986), Khemanie et al. (1988), Maule (1966), Naylor (1975), Newman (1975, 1981, 1991, 1998), and Taylor and Baskerville (1994). The analysis by Bliss is especially useful throughout this section, and a general reference is gratefully acknowledged.
} 
But mining prospered because investors viewed gold and silver as safe-haven assets. By refining these metals from composite ores, the widely held firms Noranda and Cominco grew, increasing the importance of the widely held sector.

New family fortunes also arose in the 1930s. Armand Bombardier's "snowmobiles" hit the market in the late 1930s. Kenneth Colin (K.C.) Irving built his family store into a new pyramidal group of gas stations, busing, trucking, auto sales, and bus making. Roy Jodrey, who first lost a considerable fortune, built his United Service bus line, as well as a chain of gas stations and auto dealerships, into a new pyramid. John and Alfred Billes built Canadian Tire into a large national retailer during the 1930s. Roy Thompson overcame a bad credit record to buy a radio station and then a newspaper. After paying back taxes, beverage exporters formalized their market shares in the post-prohibition United States. Edward Plunkett (E.P.) Taylor built up a new major player, the Brewing Corporation of Canada. Charles Trudeau sold his chain of gasoline stations and Automobile Owners Association Service Clubs to buy stocks precisely at the 1932 low, greatly magnifying his already creditable fortune. This provided his son, Pierre, a life of great privilege.

Clarence Decateur (C.D.) Howe, an MIT graduate and professor at Dalhousie University, built a huge empire of grain elevators, and then lost it. C.D. Howe was well disliked - the CPR president remarked, "He is not able to deal with ordinary individuals except on the basis of a superior dealing with inferiors." 49 However, as King's "Minister of Everything", Howe was the most powerful force in the economy through the middle of the century.

During World War II, Howe ran the centrally planned wartime economy as Minister of Munitions and Supply. By 1945, with European and Asian factories in ruble, Canada was the world's third largest economy by some measures. A wartime alliance with the Soviet Union, and memories of the Great Depression amid centrally planned prosperity, brought votes to the socialist Cooperative Commonwealth Federation (CCF), later renamed the New Democratic Party (NDP). The CCF outpolled both the Liberals and Tories in 1943, and took power in Saskatchewan in 1944. This, even more than the Progressives, deeply disturbed the country's polity. King countered by moving the Liberals leftward, absorbing moderate socialists to make the CCF disagreeably radical. In 1944, he let unions organize and compel collective bargaining, and made Howe Minister of Reconstruction and Supply.

After the war, Howe liberalized the economy despite the objections of the CCF and business groups wanting state enforcement of their cartels. A mass-privatization of wartime enterprises created yet more widely held firms. ${ }^{50}$ The 1950 s and 1960s in Canada were a near continual boom, though not as energetic as the Laurier years or late 1920s. After King retired, Howe served the new Liberal Prime Minister, Louis St. Laurent. His heavy handed use of War Powers to organize a major pipeline project in 1956 cost the Liberals the 1957 election. But Howe's legacy was an economy mostly organized by market forces, save for a string of grand nation building projects - a national airline, the trans-Canada highway, an aerospace program, a transcontinental oil pipeline, and the like.

The new Tory Prime Minister, John Diefenbaker, an upstart lawyer born in a shack in rural Saskatchewan, had little use for great nation-building schemes or business lobbyists. The decade and a half following the war was probably the apogee of free market philosophy in Canada. Growth slowed after 1957, but revived in 1961 and remained brisk through the sixties.

European and Japanese reconstruction fueled demand for metals and wood. Several new mining companies emerged during this era. The Iron Ore Company of Canada was organized by Hollinger, Timmins, and the Hannas family of Cleveland. Gunnar Gold Mines, run by Gilbert LaBline, whom Howe fired from El Dorado, developed a huge uranium mine. Joe Hirshhorn struck uranium, and sold out to Rio Tinto and Rio Algom. A Czech migrant farm worker, Stephen Roman, bought claims near Hirshhorn's operations and found more uranium. His Consolidated Dennison Mines quickly became a major producer.

Many older companies also became widely held after the war. MacMillan took over Bloedel, Stuart, and Welch to form MacMillan-Bloedel, which became widely held. Alcan Aluminum became widely held after a US court ordered its parent, Alcoa, to divest some assets. Hiram-Walker, Hydro-

\footnotetext{
${ }^{49}$ Quoted in Bliss (1986), p. 443.

${ }^{50}$ Howe retained state control in key industries, keeping Polymer, a plastics manufacturer, and El Dorado, a mining firm with uranium holdings he had nationalized in 1944.
} 
Electric, Fraser, Shawinigan Water \& Power Co, and Great Lakes paper also passed from family control to become widely held.

But other pyramidal groups were on the rise. The Sobey and Steinberg families built groups from land development and food retailing. Simard, Demarais, and Basset built new corporate groups in Québec. Older empires also flourished in the war's aftermath - the Irving group in New Brunswick, the Billes family's Canadian Tire, Roy Thompson's media group, and the Bronfman's distilleries.

The most important creation of this period, however, was the Argus Group, a vast pyramid run by EP Taylor, whose Canadian Breweries provided a bountiful cash flow. He expanded into food with Canadian Food Products and soft drinks with Orange Crush. He took control of Massey-Harris and, with auto glass heir Eric Phillips, took over Standard Chemicals. In 1945, he reorganized his holdings, plus William Horsey's Dominion Stores and other firms, into a classic pyramid. Argus Corporation, the apex firm, was $50 \%$ owned by Taylor, with Horsey, Phillips, and several others owning lesser stakes. Taylor believed all industries evolved towards monopoly, and sought to position Argus to benefit from this.

George Black, a professional manager, helped Taylor grow Argus rapidly. Argus expanded into Europe, merging the British tractor firm Ferguson into Massey-Harris. The group acquired control of a posy of family forestry firms, consolidating them into British Columbia Forrest Products, and entered broadcasting by taking control of Standard Broadcasting. Argus subsidiaries were also aggressive acquirers. Standard Chemicals took control of Dominion Tar and Chemical (Domtar) and of pulp and paper companies like St. Lawrence Corporation and Donnaconna Paper. British Columbia Forest Products took over a series of family-controlled firms. Like the Galts in the $19^{\text {th }}$ century, Taylor got into the land business too, building the new city of Don Mills, Ontario, as a single project.

The period saw a changing of the guard in top corporate offices. Isaac Walton Killam and Sir James Dunn both died in the mid 1950s. Howe decided that Algoma should become widely held, and sold Dunn's shares in several small blocks. Killam's heirs broke up that group and sold out. Widely held firms now dominated the large corporate sector - despite a series of nationalizations by the Québec government and more foreign takeovers, like that of the widely held Algoma Steel by Mannesmann and of Westcoast Transmission by Philips Petroleum.

The Argus pyramid remained the largest, though Taylor had retired. A team of professional managers, led by Albert Thornborough, a Harvard MBA, ran Argus well, with Canadian breweries, Dominion Stores, and Massey-Ferguson all growing at sustained double-digit rates. By the 1960s, Massey Ferguson was a major multinational in its own right.

Fueled by its oil and gas wealth, Alberta was now a major center of economic activity. New widely held companies, like Alberta Gas Trunk Lines, Dome Petroleum, Hudson's Bay Oil and Gas, and others rose to national prominence. Vancouver also became a major center to rival Toronto and Montreal.

However, Canada was changing. In a landmark 1965 book entitled The Vertical Mosaic, John Porter (1965) argued that an Anglo-Scots elite still held virtually all the levers of economic and political power in what was now a distinctly multicultural country. The need to dislodge this elite would become, in many guises, the central political issue of the next quarter century. Increasingly educated Québécois demanded to be maîtres chez nous - "masters in our own house". The immigrants populating the increasingly economically important western provinces (and Toronto) were neither British nor French, and many felt alienated from the whole national debate.

The Liberal Lester Pearson succeeded Diefenbaker in 1963, and launched a variety of social programs, including National Health Care. Pearson's economic philosophy was probably not greatly different from Diefenbaker's, but his minority government dependent on the socialist N.D.P. This began a new trend towards greater state intervention in the economy. Pearson stepped down in 1968; and the wealthy Université de Montréal law lecturer, Pierre Eliot Trudeau, won the Liberal leadership and took power. Trudeau saw himself as a scholar, interested in philosophy, social justice, and constitutional law. He was profoundly bored by economics, though he audited a Harvard class by John Kenneth Galbraith.

Figures 6 and 7 highlight an abrupt turning point at this time. The steady rise of widely held firms reverses. A few, like Hunter Douglas, failed. But the main reason for this reversal seems to be a flurry of control block acquisitions by new and old pyramidal groups. 
In 1978, Conrad Black inherited a block of Argus, acquired control of the apex company in a series of complicated deals, and then dismantled the entire group. ${ }^{51}$ Black sold control blocks into the rising merger wave of the $1980 \mathrm{~s}$ - some to other wealthy families and others, like Massey Ferguson, to the public. Black retained yet others, including Dominion Stores, in his Hollinger group, which he built into an international newspaper group. Lord Black remained a power in the newspaper business until overwhelmed by allegations of scandal in the early 2000 s.

Sam Bronfman passed control of his empire to his sons and grandsons, but his nephews had to be bought out. Sam's brother was a partner early on, and his nephews therefore had a legitimate claim. ${ }^{52}$ Thus, Edward and Peter Bronfman obtained a cash hoard to establish a second, separate Edper Bronfman pyramid that would eventually overtake the first.

The Edper group grew rapidly through the 1970s and 1980s, acquiring control of several large previously widely held firms, including Brascan and Noranda. Noranda, in turn, took control of British Columbia Forest Products, a former Argus firm, and amalgamated it into Crown Forest Products to form Fletcher Challenge Canada. Noranda also took a $48 \%$ control block in the previously widely held MacMillan Bloedel. Meanwhile Brascan took a control block in Great Lakes Power, also formerly widely held.

Other widely held firms joined other great pyramidal groups during the Trudeau years. The Power group took a control block in Dominion Glass. The Reichmanns bought much of Taylor's Toronto real estate. Their flagship Olympia \& York took control of Abitibi Paper, Abitibi-Price, and Gulf Canada - the last after its parent spun off its Canadian operations.

And family firms took over widely held firms too. Molsen and Labatt's, together, took control of the formerly widely held Canada Malting. The Gordon family assembled a control block in Canadian Corporation Management.

The Trudeau Liberals sought a just society, and distrusted markets. An alphabet soup of federal agencies began micro-managing "strategic industries", like energy and the media. Complicated systems of taxes and subsidies redistributed income across corporations and regions. By the mid 1980s, the economy was floundering and anger in Québec and the western provinces escalated.

In 1985, Brian Mulroney's Tories routed the Liberals and redirected the country back onto a free markets path. In 1987, the Tories relaxed the rules forbidding banks from owning other companies, and they quickly acquired control of all the main trust companies, investment banks, and other financial services companies. And in 1989, Mulroney signed a free trade agreement with the United States, finally burying MacDonald's National Policy. But many Trudeau era programs were entrenched. Cutting regional and industrial development funds, tax advantages and business subsidy programs proved politically impossible. Dissention within Tory ranks over this issue fractured the party, and the Liberals, under Jean Chrétien, and later Paul Martin, held power after 1993.

The Mulroney Tories ran Canada's second mass privatization, floating Air Canada, the Canadian National Railway, PetroCanada, Polysar Chemical and Energy, Westcoast Energy, and other state-owned enterprises. Though often lengthy and multistage, all eventually led to freestanding widely held firms.

But the great family groups more than made up for this. The Reichmanns took control of Hiram Walker Resources. Interprovincial Pipe Lines took control of Consumer's Gas, and was then acquired by the Reichmann group. The Edper group took control of Falconbridge and Fraser, and expanded its existing businesses with debt financing.

In the early 1990s, both the Reichman and Edper Bronfmann groups were overleveraged. The Richmanns lost some of their properties to creditors; and Edper divested John Labatt \& Co. as a widely held firm, though it was later taken over by a Belgian conglomerate.

After the Tories enacted an unpopular consumption tax, the Liberal Prime Minister Jean Chretien took power in 1993. Chretien was a Trudeau liberal, but the party was now more moderate, and finished

\footnotetext{
${ }^{51}$ His motives are unclear, for diversification was not yet out of vogue. Newman (1998) notes that E.P. Taylor, the architect of Argus, fired Conrad's father, George Black. George invested successfully through the 1960s and put the money into Argus, perhaps contemplating a takeover.

${ }_{52}$ The two Bronfman branches separated in 1952, establishing two trusts, Cemp and Edper. In early 1960s, Sam purchased Seagram shares from Edper at lower-than market prices, causing resentment. The final split occurred in 1968, when Edper tried to acquire Great-West, which was eventually taken over by the Desmarais Group.
} 
the incomplete privatizations of Canadian National and PetroCanada.

Newman (1998) makes much of a new elite taking charge of Canadian business in the 1990s, writing of the death of the "Jurassic Canadian Establishment." He correctly notes (p. 5) that the old elite

\footnotetext{
"practiced insider trading with exuberance, feathered each others' nests with considerable grace, maintained their workers in patronizing insecurity, and, with the instincts of an unregulated oligarchy, gleefully forced competitors out of their misery" and "operated in what was a virtually risk free environment ... nurtured by government subsidies having formed a cozy marriage with the political establishment."
}

Several grand old families, such as the Eatons and Woodwards did indeed reap the fruits of long years of mismanagement in the 1990s, and largely disappeared from the headlines. Newman may be right that the old establishment lost influence because of its British ideal of "lovable dimness" (p. 13).

But Figures 6 and 7 attest that Canada at the end of the $20^{\text {th }}$ century looks much as it did at the beginning. Much of the domestic private sector consists of large family controlled pyramidal groups.

The lineal descendents of Sam Bronfman were ruined by their foray into Hollywood, but the Edper Bronfman group remains the largest in the country. The Reichmann group, after stumbling badly in British property investments, recovered and still ranks second. The Thomson group acquired control of the venerable Hudson's Bay Company. The venerable Power group is now controlled by the genuinely entrepreneurial Paul Desmarais.

New corporate groups have arisen. Jimmy Pattison built a used car lot into a large business group. Peter Munk, a penniless Hungarian Jewish refugee, built a huge corporate empire. Tainted with insider trading allegations, he moved to the South Pacific to build a hotel empire. Plowing his hotel profits into the Canadian mining firm Barrick restored his standing, but his positing bail for the Arab arms dealer Adnan Kashoggi troubled some. Semour Schulich, another new baron of Canadian business, joked famously "reputation is character minus what you can get away with."

Thus, while merger activity corresponds to business cycle peaks, no clear pattern emerges relating ownership structure changes to either. The boom of the 1920 s and the prosperous mid-century decades correspond to a rising importance of freestanding widely held firms. Families cashed out into what were probably overvalued markets, and new widely held firms grew rapidly. Entrepreneurs tapped public equity to build new firms in industries like mining. Boom and bust alike increased the importance of widely held firms through the 1960s, and then boom and bust alike reversed this. Family pyramidal groups grew rapidly in the 1970s and early 1980s. A brief resurgence raises the profile of widely held firms in the late 1980s and early 1990s, but only slightly. This reflects a mass privatization that created new widely held firms, even as others were absorbed into pyramidal groups and a brief bout of financial problems that pruned back two large pyramidal groups.

Thus, although merger waves are unquestionably periods of more rapid change in ownership structure, as are business cycle troughs, no clear pattern emerges. The conditions under which booms and busts raised diffuse ownership do not seem systematically different from those under which diffuse ownership faded away. Understanding the historical determinants of corporate ownership structures therefore requires more nuanced considerations of the institutional changes affecting these periods.

We therefore put under the microscope changes in financial development, tax policy, competition policy, labor rights, shareholder rights, industrial policy, trade policy, and cultural policies. Our objective is to see if any of these track changes in ownership structure.

\section{Financial Development}

Rajan and Zingales (2003) describe a "Great Reversal", in which many countries' financial systems shrank over the first part of the twentieth century, and the rose again in the century's last two or three decades. They report such an event for Canada, measuring financial development by the size of both the banking system and stock market. Figure 8 charts their measures of financial development for Canada and the United States through the century. 
Figure 8. The Size of the Financial System Relative to the Economy

Evolution of commercial and savings deposits (bank loans) and total market capitalization (stock markets), both as percentages of gross domestic product. Missing data on the size of the Canadian stock market in 1938 is estimated using the ratio of trading volume to market capitalization for other years.

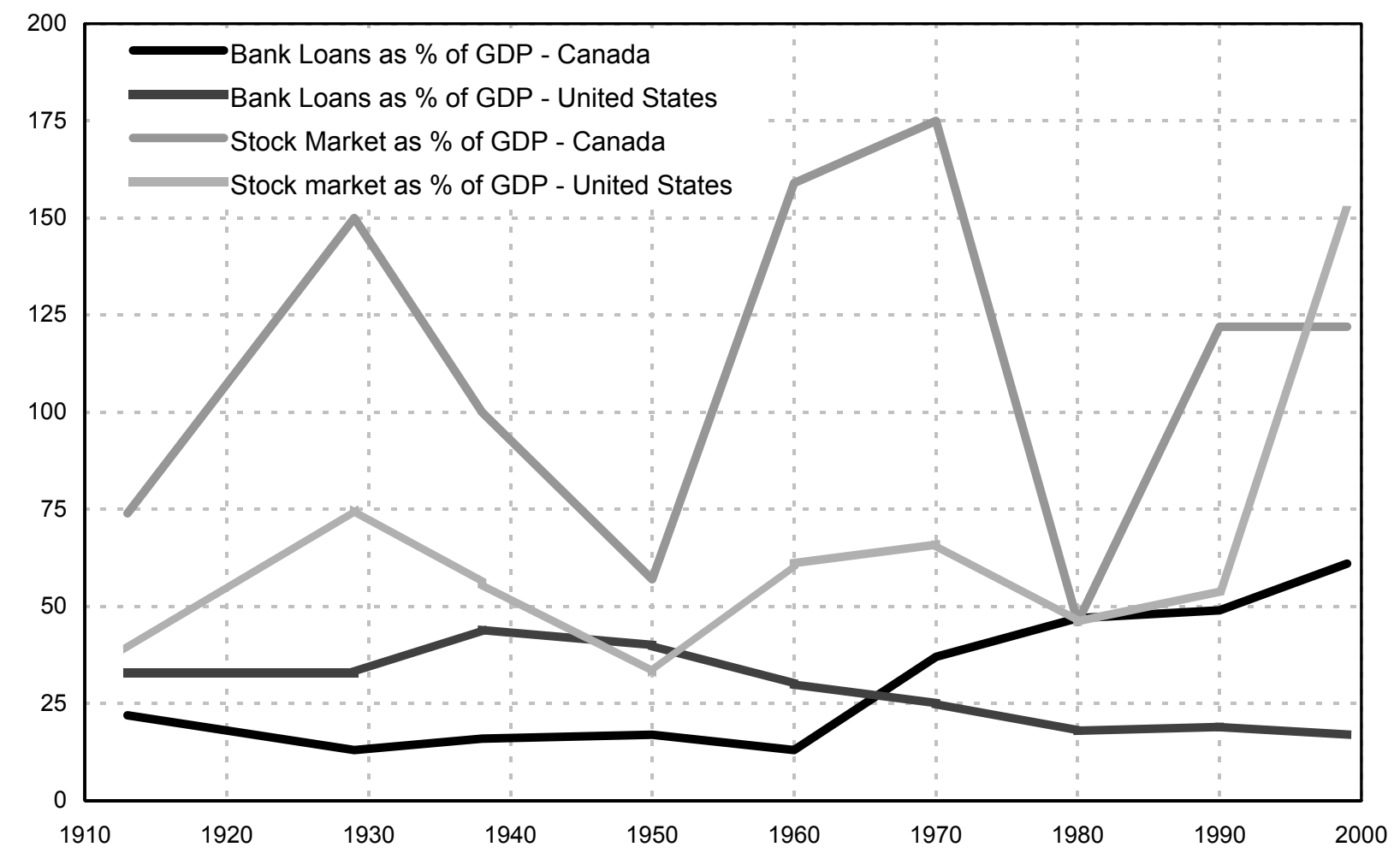

Source: Rajan and Zingales (2004)

Canada's banking system underwent a profound crisis in the 1920s and another in the 1930s. World War I inflation ushered in several years of deflation, bankruptcies, and bank failures. Much merger activity in the early and mid 1920s involves government orchestrated consolidations of healthy banks with distressed ones in the early 1920s. By 1928, Canada had only ten chartered banks, down from thirty in 1910. The last narrowly held family bank, Molson's Bank, was taken over by the Bank of Montréal. The downturn wiped out several of the professional managers running former Aitkin group firms and several old family fortunes, contributing to the decline in importance of family groups.

In the late 1920 s, the stock market was effervescent, and clearly overvalued. For example, investors valued the troubled radio firm Canadian Marconi, with $\$ 5$ million in assets, at over $\$ 130$ million in 1928. Heirs to the family groups built by Massey, Dunsmuir, McLean, Simpson, and others sold out via public equity offerings. Again, this broadened the ranks of freestanding widely held firms.

Stocks collapsed in 1929, and unemployment rose. The new Prime Minister, R.B. Bennett responded to the crisis by leaving the gold standard. The dollar immediately fell precipitously, and foreign lenders called in their loans. Major investment houses, like McDougall \& Cowans, Greenshields \& Co., and Watson \& Chambers, failed. To avert a financial collapse, the Bennett authorized banks and insurance companies, almost all now insolvent, to use "special valuation methods" to convince the public of their soundness. ${ }^{53}$ Canada barely escaped a sovereign default through a National Service Loan, floated on wartime rhetoric in a huge advertising campaign. The top fifty stocks dropped an average of $85 \%$ from their October 1929 highs to their May 1932 lows.

For the next half century, the banking system was very stable. The 1967 revision to the Bank Act bestowed ten percent voting caps on all chartered banks - making it illegal for any single shareholder to own a stake larger than this. The politics surrounding this seem to be public concern about foreign

\footnotetext{
${ }^{53}$ For details, see Kryzanowsky and Roberts (1993).
} 
control of Canadian banks, or at least concern by important lobbying groups. The banking system remained highly regulated until the Mulroney Tories took power in the mid 1980s. They slowly unwound longstanding prohibitions on banks owning other financial services businesses. Over the next decade, Canada's five major banks took over all large brokerage houses, underwriters, and trust companies.

All this is reflected in Figure 8, which shows bank loans declining as a fraction of GDP after the Laurier boom, and not surpassing 1913 levels again until 1970. In contrast, the US banking system actually expanded as a percentage of GDP until roughly 1938, and then slowly receded as the stock market grew more important. The economic importance of both countries' stock markets peaked in 1929 and again at about 1970. The Canadian stock market was much more important economically than the United States market in the 1920s boom and again in the 1950s and 1960s.

Thus, large Canadian firms grew steadily more widely held when the stock market was large relative the economy, and the banking system small. The shift back to narrower ownership very roughly corresponds to a period when the stock market was less prominent and the banking system more important.

Beck and Levine (2002) show that both bank and stock market based financial systems can fuel growth. However, little is known about the weather the distributions of wealth and corporate control that emerges from such growth differ. Banks are thought to depend more on relationships in making financing decisions, and stock markets are more impersonal. It is possible that family business groups have a greater advantage when banks are more important, since a single relationship covers many firms. Daniels et al. (1994) show that Edper Bronfman group firms were substantially more leveraged than otherwise similar freestanding firms, perhaps consistent with this hypothesis.

However, the size of the financial system is not God-given. It depends on other institutional features of the economy. Relating ownership structure to the structure of the financial system only pushes the question out one level. What determines this? And what other factors might be in play?

\section{Taxes}

Taxes changed substantially over the century. One major change that might have affected the relative attractiveness of stocks was the introduction of a capital gains tax by the Trudeau Liberals in 1972. This corresponds to the abrupt decline of the stock market relative to the economy's size. Since this also corresponded to the beginning of a prolonged high inflation period, stocks probably rendered especially unattractive, as the tax applied to inflationary as well as real gains. However, the stock market did not resume its prior importance in the 1980s, when inflation abated. Moreover, several other events also occurred at approximately this time, so causality is hard to infer.

One of these events, also involving the tax system, was clearly related to corporate ownership diffusion. Canada had very high succession taxes in the middle of the century, but virtually no succession taxes, at least on very large estates, at the century's beginning and end. Could this have affected the viability of large corporate groups at different times?

Prior to World War I, Canada's main source of tax revenue was the tariff and its main public expense was industrial subsidies. However, the incessantly rising subsidies first Laurier, and then Borden, needed for what would become the Canadian National Railway, plus an accumulating war debt, forced the government to devise additional revenue sources. In 1916, parliament had passed an excess corporate profits tax to fund the war. When this lapsed, it enacted a permanent manufacturers' sales tax at six percent. Corporate and personal income taxes, enacted in 1917, rose sharply - top marginal rates for both soon surpassed fifty percent. To avoid double taxation, dividends and capital gains were exempt. In 1926, dividends became taxable personal income, but intercorporate dividends remained exempt, allowing pyramidal groups to continue.

Unemployment relief was constitutionally a provincial matter, and the provinces all needed tax revenues. Ontario introduced a "succession tax" in 1892, and by 1894 all the other provinces followed suit. Although England introduced death taxes in the $18^{\text {th }}$ century, many American states levied them from the $1820 \mathrm{~s}$ on. Thus, succession taxes were decried as Americanization of Canada. ${ }^{54}$ Although the original rates were in the five to ten percent range, by the 1930s top marginal rates were as high as thirty

\footnotetext{
${ }^{54}$ For example, Bayley (1902) writes that the "Ontario Act of 1892 was purely American in origin."
} 
percent. Smith (1993) finds that succession duties accounted for a significant share of provincial revenues during the 1930 s.

In 1941, the federal government enacted a federal succession tax to generate war revenue, but it was always envisioned as permanent tax. Rates rose quickly and approached provincial levels by 1947. That year, the federal government doubled the rate to fifty-four percent and offered half its take to provinces that withdrew their taxes. Seven did. Ontario and Québec retained their own succession taxes, which could be credited against federal tax.

These taxes took a substantial bite out of corporate groups as the business elite of the 1920s passed away. For example, both the Killam and Dunn estates were broken up to pay death taxes in the 1950s. The government's $\$ 100$ million boon financed university expansions and established the Canada Council. To pay these tax bills, the heirs sold stock and a new cadre of widely held firms came into being. These included Calgary Power, once part of the Killam group, the Algoma Central \& Hudson Bay Railway, formerly controlled by the James Dunn, and many other firms. Many large free standing family firms, for example Burns \& Co., also became widely held upon the death of their patriarchs.

As governments expanded, federal income taxes and taxes in most provinces rose to Scandinavian heights. However, Alberta began competing for wealthy family investments by promising to rebate its share of the succession taxes collected by the federal government. This tax competition threw the entire succession tax system into disarray; and Trudeau decided to abolish it entirely in 1972. Inheritances were now tax-free income. In place of the old estate tax, the Liberals now taxed capital gains, including capital gains upon death. However, a huge loophole allowed the transfer of assets to a family trust, which deferred capital gains taxes for two generations. The Bronfman heirs escaped capital gains taxes entirely by moving their wealth out of Canada before capital gain taxes fell due on their family trust.

Thus, succession taxes seem to have played an immediate role in the break up of several large pyramidal groups and the creation of widely held firms of their remnants. However, this too is hardly a complete explanation. The Killam and Dunn heirs could have sold their shares to other controlling shareholders, rather than the public. In the 1950s, public shareholders must have offered a better price. Succession taxes are probably part of the story, but only part. It may be that the absence of capital gains taxes caused small investors to be more generous before 1972, but this is far from clear.

\section{Competition Policy}

Demsetz and Lehn (1985) argue that product and factor market competitive pressures weed out firms with suboptimal ownership structures. If, for example, widely held firms have worse agency problems, as in Jensen and Meckling (1976), they might be more commonplace when product and factor market competition eases, but less evident in periods of brisk competition. This suggests that we examine the strength of competitive pressures at different periods.

Canada had no real antimonopoly legislation through most of the century. MacDonald's AntiCombines Law of 1889 legalized price fixing by making restraints on trade actionable only if they "unduly" or "unreasonably" lessened competition. Thus, fairly overt cartels are a recurring feature of Canadian business history.

In particular, restraints on bank competition were acceptable. For example, the Journal of the Canadian Banking Association wrote in 1898 that

"[T]here should be certain things universally considered unprofessional within our ranks. Giving service without profit or at an actual loss should be unprofessional. Solicitation of business by offering to work more cheaply should be as unworthy of a banker as we consider it unworthy a doctor. $" 55$

The Canadian Bankers Association was formed in 1891 to fix interest rates and other bank fees. ${ }^{56}$ It was Canada's most important industry association, for parliament granted it the legal power to block charters for new banks, to reduce deposit interest rates, and increase loan rates. It lobbied successfully for an abolition of government savings accounts that "drained the lifeblood of the country."

\footnotetext{
${ }^{55}$ Quoted by Bliss (1986) pp. 360-61.

${ }^{56}$ Bliss (1986) p. 361.
} 
The flawed Anti-Combines Law seemed a deliberate shot into its own net by a government of vested interests. Yet it was not replaced until 1989, when the Mulroney Tories brought in a new law. Canada thus had no real antimonopoly law until 1989 - long after the rise and fall of the widely held firm in Figures 6 and 7. Competition policy per se is thus not responsible for changes in ownership structure.

However, the government affected the intensity of competition in other ways. In the 1930s, Canada was hit badly by the Great Depression and a sustained deflation, which the Retail Merchants Association of Canada loudly blamed on predatory pricing by 'big business'. The Tory Prime Minister, R.B. Bennett's solution was the 1934 National Product Marketing Act, which enforced the cartelization, through marketing boards, of any industry whose producers so desired. Businesses from barbers to taxicabs were quickly cartelized under the direction of trade associations. Reynolds (1940) writes

\begin{abstract}
"The Canadian associations perform scarcely any of the service functions which characterize trade associations in the United States. General statistical services, institutional advertising, cooperative research, and the like are very rare. The Canadian associations center upon the maintenance of 'fair prices' and it is judged largely by its success or failure in this field. One trade association secretary, indeed, remarked that 'manufacturers up here wouldn't be bothered with an association that couldn't control prices." ${ }^{, 57}$
\end{abstract}

Although Bennett vigorously denounced laissez faire in a cross-country radio address in 1935, he was no socialist. An enthusiastic imperialist and thoroughgoing Tory, he sought only to protect established business from instability, not unlike the Tories of the Family Compact a century earlier. Hankin (1933) summarizes the prevailing Canadian economic philosophy thus:

"There must be planning, order, and cooperation in economic affairs between individuals, groups, and nations or disaster will overtake us all.",58

The economy deteriorated further, and Bennett lost the 1935 election to Mackenzie King's Liberals. King repealed some of the cartel enforcement legislation, but similar provincial laws soon supplanted it in everything except agricultural products and banking. Federally enforced cartelization remained in place until the 1990s for most agricultural sectors, and still endures for wheat, eggs, and dairy products. Provincial cartelization created trade barriers within Canada, some of which are still in place for example, blocking interprovincial beer sales.

During World War II, King's "Minister of Everything”, C.D. Howe, reorganized the economy for the war effort. To manage the private sector, he took key industrialists and representatives of wealthy families into the government as dollar-a-year men and assigned them production targets. The War Measures Act and Wartime Prices and Trade Board kept wages and prices low as production surged. The War Contracts Depreciation Board granted case-by-case accelerated depreciation tax deductions. If a contractor's profits seemed too high, Howe renegotiated the deductions down or levied an Excess Profits Tax. If no private firm could deliver on Howe's terms, he established a state-owned enterprise. Both entrants and business failures were vanishingly rare.

After the war, Howe ended wage and price controls, and curtailed officially-sanctioned price fixing by most industry associations in 1951. The economy was probably soon as competitive as before the Great Depression. As various rounds of trade negotiations slowly lowered MacDonald's National Policy tariffs, imports further stimulated competition.

The Trudeau Liberals probably lessened competition in the 1970s and early 1980s through an extensive program of nationalization, aimed at restructuring the economy to limit foreign control and execute industrial policies of various sorts. The most invasive, and economically disastrous, of these was the National Economic Policy. The NEP set all energy prices and subjected that industry to an intricate system of taxes and subsidies designed to shift oil and gas production onto federally owned land in the Arctic. The program devastated the existing oil and gas industry and ultimately led to no new production in the North. However, ordinary rules of competition clearly ceased for the duration of the program.

Finally responding to decades of complaints by economists and consumer groups, the Mulroney Tories proclaimed a new Anti-Combines Act in 1989. Less focused on concentration ratios and more on

\footnotetext{
${ }^{57}$ Quoted in Bliss (1986), p. 427.

${ }^{58}$ Quoted in Bliss (1986), p. 428.
} 
entry barriers than the comparable United States law, the new act is a more serious barrier to price fixing. The Mulroney Tories also ended most remaining Depression era cartelization. Canada's corporations are thus probably subject to more competitive pressure now than at any time in history.

Thus, enforced cartelization and war economy programs probably restrained competitive forces severely from the 1930s through the end of World War II. Competitive forces probably picked up after the war, died down in the 1970s and early 1980s, and picked up again thereafter. Supplementing the history of Anti-Combines policies with that of cartelization policies still yields a pattern at odds with that of corporate ownership. Widely held ownership expanded as competition eased in the Depression and war economies, and then picked up through the 1950s and 1960s. Widely held ownership abated as the Trudeau Liberals reduced competitive pressures, and continued to ebb after the Mulroney Tories brought in the first real antimonopoly laws. This does not disprove the theory of Demsetz and Lehn (19xx), for subtler renditions of it are possible. But there is clearly no simple pattern linking ownership structure to the likely briskness of competition.

\section{Labor Rights}

Roe (2003) argues that, in countries that give workers extensive legal rights, companies need strong shareholders to balance this. He shows that developed countries with stronger employee protection laws have more concentrated corporate ownership structures, including pyramidal ones. How does this hypothesis fit Canadian historical data?

Billionaires of the Laurier era had little regard for their workers or public welfare in general. Although they could relocate Scottish castles to Toronto and build Tudor palaces on Vancouver Island, the major charitable foundations in Canada were the Ford and Carnegie Foundations. Canadian tycoons and wealthy families funded local good works, but none remotely considered charitable giving on the scale of Bell, Carnegie, or Hershey. Instead, the new rich, like the old, planned dynasties. Although sporadic strikes and occasional labor unrest affected $19^{\text {th }}$ century Canada, labor was generally accepting of its station. Labor unions were deeply antithetical to the traditional Catholic values of Québecois habitants and the Tory traditions of United Empire Loyalists. Voices for both condemned unionization as lamentable Americanization of the country. Certainly, business saw no need to be generous. The British Columbia tycoon Robert Dunsmuir instantly fired any employee he thought was even contemplating any connection to organized labor, perhaps setting the stage for that province's union militancy.

But World War I inflation and the postwar recession, aided by aided by the American Federation of Labor expanding into Canada, raised a backlash against concentrated wealth. Wartime inflation roughly doubled the cost of living by 1920, and fixed wages could no longer be justified out of patriotism. Union membership grew by $50 \%$ in 1919 , and strikes paralyzed Canada's major cities, with the bloody Winnipeg General Strike attaining Bolshevik proportions.

Labor relations deteriorated in the 1920s, when Roy Wolvin and other former Beaverbrook associates created British Empire Steel from a merger of Nova Scotia Steel and Coal, Dominion Coal, Dominion Iron and Steel, Dominion Steel, a Halifax shipyard, and several other firms. Their timing could not have been worse, for steel prices collapsed and BESCO died, slowly. Wolvin slashed wages, and a genuine class war burst forth. By 1922, a full third of the Canadian Army guarded BESCO plants. One commanding officer even called in air strikes. ${ }^{59}$ Nova Scotia labor was irredeemably radicalized, and this may have cost Atlantic Canada its industrial edge. And one of the great pyramidal groups from the Laurier era was in tatters.

The Liberal Prime Minister MacKenzie King dismissed talk of unemployment as subsidy-seeking by provincial governments, and lost the 1930 election after quipping that he would not give a nickel to help a Tory provincial government alleviate "alleged" unemployment. ${ }^{60}$ The new Tory Prime Minister, R. B. Bennett, was a corporate lawyer and long-time associate of Max Aitken. Married to the heiress to the E.B. Eddy Company, he was also a millionaire. Bennett also had little use for labor "agitators".

C.D. Howe, unlike his counterparts in the other Allied countries, did not invite labor representatives to participate in planning the wartime economy. Strikes grew more frequent as the war wound down, and public opinion shifted towards unions. The agrarian socialist Cooperative

\footnotetext{
${ }^{59}$ See Bliss (1986, p. 389) for details.

${ }^{60}$ Bliss (1986, p. 415).
} 
Commonwealth Federation (CCF) party, championing social security and labor rights nearly won elections in Ontario and British Columbia in 1943, and won power in Saskatchewan in 1944.

King, having learned from his past mistake, issued an Order in Council (executive decree) in 1944 granting trade unions the right to organize and compelling collective bargaining. This was a sea change - from virtually no legal rights to substantial union powers. A wave of strikes engulfed the country as workers exercised their new rights.

In 1945, the courts found that all employees, even nonmembers, must pay union dues and that employers must collect them. This enabled unions to hire legal experts, lobbyists, and public relations experts. In 1961, organized labor took charge of the agrarian socialist CCF party, and rechristened it the New Democratic Party (NDP). Labor now had a clear voice in parliament, and soon exercised power through its support of a Liberal minority government. In 1965, an illegal postal strike ushered in collective bargaining for civil servants, who unionized in record numbers. This too greatly expanded the financial resources of the union movement, and the influx of civil servants radicalized its political agenda.

The Québec Federation of Labor became the most militant wing of the movement, its intellectual leaders informed by French political thinking. A new wave of strikes engulfed the public and private sectors in 1966. Especially in Québec, strikes were violent and union leaders often flouted the law.

By the late 1970s, the rest of the public largely lost sympathy with unions, and union membership in the private sector plummeted in the 1980s. Unionized firms and industries downsized and failed, and new firms and industries took extraordinary measures to avoid unions. However, overall union membership remained much higher and union finances much stronger than in the United States because of public sector unions.

However, NDP governments intermittently held power in British Columbia, Saskatchewan, Manitoba, and Ontario; and the separatist Parti Québécois, whose labor policies paralleled those of the NDP, won power in Québec. Provincial labor legislation strengthened labor bargaining position further in these jurisdictions. Liberal governments in the Atlantic provinces also became champions of labor rights.

In summary, labor rights remained very weak in Canada until 1945. They grew stronger in 1965. Unionization in the private sector fell from the 1980s on, but labor rights remained unchanged, and even grew stronger in certain provinces. If strong labor rights necessitate strong controlling shareholders, we should see predominantly widely held firms until 1945, and then a steady increase in ownership concentration, especially after 1965. This is not observed. Roe's (2003) theory thus loosely explains the fall of the widely held firm after the 1960s, but not its rise over the first half of the century.

\section{Shareholder Rights}

La Porta et al. (1999) argue that large widely held firms currently dominate the ranks of large corporations in the United States and United Kingdom because those countries provide investors with better legal protection against pilfering by insiders and asset appropriation by corrupt officials. Small investors have limited resources for monitoring firms to detect such problems and intervening to correct them. Consequently, small investors only hold common shares in numbers sufficient to render most large firms widely held where they feel protected against such abuses. Also, corporate insiders get a higher price, all else equal, for shares issued to small investors where public shareholders legal rights are strong. Weak legal rights for small investors thus make them less interested in holding shares and corporate insiders less interested in selling shares to the public.

This line of reasoning, developed more formally by Burkart et al. (2002), suggests that widely held firms should become more commonplace as shareholders' legal rights grow stronger. Did shareholder rights grow stronger through the first half of the century and then somehow erode?

Armstrong $(1986,1997)$ traces the historical development of shareholders rights. Canada's corporate governance laws early in the century were extraordinarily weak. ${ }^{61}$ A 1906 Royal Commission on Life Insurance exposed extensive tunneling in the Mackenzie-Cox pyramid, with money flowing from insurance companies to power companies, as well as extensive insider trades by the pyramid companies in

${ }^{61}$ See Armstrong (1997) for a detailed review. A good summary is also provided in Boothman (2000). 
each other's stocks. ${ }^{62}$ The result was a 1910 law tightening investment rules and reporting standards - for insurance firms only.

Corporate governance was essentially a matter of private reputation, constrained loosely by vague and often contradictory provincial statutes and common law precedents. No federal corporation law existed until 1910, and that law required no annual general meetings. Until 1917 they needed only hold meetings every two years, and then only to elect the board. Only Ontario required annual shareholder meetings. The law mandated neither minority shareholder rights nor fiduciary duties by officers and directors to shareholders. Directors and officers had a "duty to the corporation" under common law, which was interpreted as trumping any duty to shareholders. ${ }^{63}$ Conflicts of interest were of no concern to the courts. Shareholders had no rights in common law to inspect books or records unless they could persuade a judge of a definite legal objective and could identify the specific records that would certainly contain the information. Auditors had no duty to inform shareholders of potential or actual misconduct; their duty was purely arithmetical. One key precedent held that auditors were "justified in believing tried servants in whom confidence is placed by the company" ${ }^{64}$ Another warned that an auditor who opines on governance "does so at his peril and runs a very serious risk of being held judicially to have failed to discharge his duty." 65

Despite the absence of clear shareholder rights, stock ownership expanded rapidly during the 1920s. A.E. Ames \& Co., Dominion Securities, Royal Securities, Nesbitt, Thompson, and Wood Gundy underwrote a boom of new issues. Ike Solloway and Harvey Mills established a chain of Solloway, Mills, \& Co. offices across the country to handle the surging investor demand. By 1929, the Alberta based firm had forty offices, fifteen hundred employees, and 13,500 miles of private wire. McDougall \& Cowans, Greenshields \& Co., and Watson \& Chambers also became major players in the investment banking and retail brokerage businesses.

Following the Crash of 1929, the Financial Post published exposés of the investment industry. As the government struggled with a huge foreign debt run up by the CNR and an expanding trade deficit, Ike Solloway was arrested and jailed.

The United States greatly expanded its public shareholders' rights in the 1930s, with the establishment of the Securities and Exchange Commission and other regulatory systems to clean up its stock markets after the abuses revealed by the 1929 crash. At the time, Canada was governed by William Lyon Mackenzie King's Liberals, and the influential senior cabinet minister, C.D. Howe, felt such regulation had no place in a capitalist country. Besides, stock market regulation was an area of provincial jurisdiction, and the provincial authorities condemned securities regulation as undue Americanization. Although provincial securities commissions were established in the 1930s, disclosure remained piecemeal and trading on insider information remained legal. ${ }^{66}$ High-pressure "boiler room" sales techniques remained an esteemed institution of Canadian finance. ${ }^{67}$ Consequently, Canada's stock markets in the 1950s still resembled the NYSE in the 1920s. Disclosure was often minimal, insider trading was a perk, and anything short of outright fraud was fair game.

Hearing of the vast riches in oil and minerals north of the $49^{\text {th }}$ parallel, small U.S. investors responded in droves to telephone pitches from Canadian boiler rooms. The lucky widows and orphans across America found themselves the humiliated owners of worthless moose pasture. The unlucky ones lacked such title, for they had all bought the same patch.

Senators and congressmen in Washington, prodded by their outraged constituents, repeatedly demanded that Canada do something. The response was always that stock market regulation was not a

\footnotetext{
${ }^{62}$ Bliss (1986) p. 370.

${ }^{63}$ Technically, the Canadian courts held, and continue to hold, that officers and directors have a fiduciary duty to the legal person of the corporation, not to the shareholders. The courts are unclear about what exactly constitutes faithful service to this fictional person. However, the courts permit officers and directors to destroy shareholder value if this benefits the corporation's legal person. Shareholder derivative lawsuits, American public investors' primary weapon against self-serving or inept corporate insiders, are therefore seldom used.

${ }^{64}$ Re Kingston Cotton Mills (1986) 2 ch. 279 at 688, 65 LJ ch 673.

${ }^{65}$ Re London and General Bank (1895) 2 ch. 685, 64 LJ ch 866.

${ }^{66}$ Bris (2000) argues that insider trading remains a greater problem in Canada than in other developed economies

${ }^{67}$ See Armstrong (1997) for details regarding the lack of reform.
} 
federal matter in Canada. After a series of especially egregious swindles, the United States threatened an embargo on investment in Canada unless the Toronto market was cleaned up. Under heavy federal pressure, the Ontario government established the Ontario Securities Commission, mandated standardized disclosure, and moved to curtail insider trading in the mid 1960s.

Shareholder rights were further strengthened as the Canada Business Corporations Act came to include an Oppression Remedy, whereby small shareholders could sue large shareholders. The Oppression Remedy quickly became small shareholders' main weapon against corporate insiders. In many ways, oppression lawsuits are superior to shareholder derivative actions because the former target the ultimate controlling shareholder, not just her professional managers. Various exchange and securities commission reforms in the 1990s further expanded shareholders' legal rights. Although solid by international standards, Canadian securities laws are probably still substantially weaker than in the United States. For example, small block holdings, executive pay, research and development, and several other critical items need not be disclosed in the same detail as in the United States.

If widely held firms become more viable when shareholder rights are stronger, they should have been rare until circa 1960 and then more common. But Canadian shareholder rights were consistently weak through to the 1960s, while diffuse ownership inexorably expanded. Then, in the 1960s, shareholder rights were abruptly strengthened, and widely held firms began to fade away. Changing shareholder rights seem a poor candidate to explain the rise and fall of the widely held firm.

Of course, laws and statutes do not necessarily make or break shareholders' legal rights. Insider norms of behavior might have risen and fallen through the century, first encouraging diffuse ownership and then discouraging it. However, we have no evidence of such a pattern. Another possibility is that judicial inefficiency or official corruption, either of which can render legal rights dead letters, abated and then resurged.

\section{Colonial Origins Revisited}

Twentieth century Canada is, by and large, not a terribly corrupt place. ${ }^{68}$ Bribes to officials are not part of everyday life. However, Canada's deep colonial mercantilist heritage gives rise to situations that resemble corruption in many ways. These situations are encompassed by the term political rent seeking, wherein businesses invest in government connections to reap subsidies, monopolies, or favorable legislation. Political rent seeking is usually not illegal, though it can be embarrassing to politicians. It is a normal activity in virtually every developed and developing economy. But, there are reasons to think that political rent seeking is more important in Canada than in many other developed countries.

As noted above, many authors argue that conditions far back in a country's history define its modern institutions and constrain its modern economy. The defining feature of Canada's colonial past is mercantilism. Canada, as a private domain of Jean Baptiste Colbert, was immersed more totally in French mercantilism than even France herself. The British who took charge retained French colonial institutions, realizing their benefit to the local elite - now themselves. ${ }^{69}$ The Loyalist refugees from the United States, victims of liberal revolutionary excesses, sought stability in the Family Compact - an institution that brought business and government intimately together. The Liberals who displaced them in the mid $19^{\text {th }}$ century immediately used their offices to divert public moneys to their businesses, resurrecting the mercantilist philosophy of Colbert and Talon. Thus mercantilism lived on in Canada long after it lost support elsewhere.

Close ties between politicians and businesses remain part of the Canadian economic landscape. These ties need not signify corruption. That Prime Minister Jean Chrétien's daughter wed the son of Paul Desmarais, whose Power Corporation controls one of Canada's largest pyramidal groups, is not associated with any improprieties. Nor is the fact that his successor, Prime Minister Paul Martin, ran Canada Steamship Lines, a former Power Company. But business-government relations in Canada often

\footnotetext{
${ }^{68}$ Though Francis (1988) details a long series of swindles, stock market frauds, and money laundering operations based in Canada, and argues that the country is much more corrupt than is commonly believed. Cameron (1994) and Savoie (1990) present evidence that official corruption in Canada is worse than is commonly believed, and Swatsky (1987) presents indirect evidence of this in passing.

${ }^{69}$ See Parkman (1867)
} 
parallel personal relationships. This always risks letting well-connected businesses capture publicspirited industrial policies.

If politicians are disposed to cut deals with certain businesses, they might find some better favor trading partners than others. Landes $(1949$, p. 50$)$ argues that family businesses are more wiling partners, and blames the weak $19^{\text {th }}$ century French economy to business families that regarded the state as "a sort of father in whose arms [they] could always find shelter and consolation." Morck and Yeung (2004) argue that family controlled pyramidal groups are more reliable partners than freestanding widely held firms for politicians. They cite a variety of reasons why old, powerful families are more capable of cooperative behavior in repeated games of reciprocal favor trading. For example, old families have longer horizons, and so more dependably repay old debts. Pyramidal groups can repay favors for one firm with cash flow from another. And powerful families can better punish politicians who fail to deliver. Thus, pyramidal groups controlled by old families might have an edge in political rent-seeking competitions.

Canada's ubiquitous corporate subsidies were often controversial, and politicians were frequently lampooned for corruption. CPR baron Van Horne well summarized the view of business leaders that "people who put pigs in office ought not to complain if they eat dirt and are bought and sold." 70 But some governments were clearly more into subsidizing nation building projects than others. We therefore see if family controlled pyramidal groups grew more important in periods when superior rent-seeking ability was probably more valuable.

Wilfrid Laurier appears to have avoided most such dealings until his last term, when he took to subsidizing railways generously. His successor, Borden, broadened and deepened these subsidies, ultimately buying out the railway men with state funds to form the Canadian National Railway.

A Progressive Movement arose out of western Canada to combat concentrated economic and political power. Sensing mixed public feelings about with mercantilist policies, Laurier made free trade the issue of the 1911 election, and lost when many Liberals defected to defend the National Policy. It soon became clear that the Progressives too sought to reform mercantilism, not bury it. A Progressive "people's power" campaign, aided by businesses lobbying for subsidized electricity, brought Ontario a provincially owned power company. ${ }^{71}$ A similar campaign in Alberta led to the state-owned Alberta Government Telephones. ${ }^{72}$ Ultimately, the Progressive Party and Tories would find sufficient common cause to merge into the Progressive Conservative Party.

Through the century, Canada's reaction to unfolding events always paralleled those of other English speaking countries, but with a mercantilist twist. Tory Prime Minister Bennett's solution to the deflation of the Great Depression was industry-organized state-enforced cartels to raise prices, clearly a return to mercantilist basics. King embraced Keynesian fiscal policy in 1945 after intense industry lobbying, especially by construction firms, as a way to extend government subsidies to businesses. Even Canadian social programs often appear first through a mercantilist lens. For example, Canada established unemployment insurance in 1940 after a sustained lobbying campaign by Arthur Purvis, the president of Canadian Industries Limited. The government was to adopt a broader insurance role to free business of the burden of retaining workers during downturns.

Mercantilism changed its character in the series of wartime and post World War II Liberal governments that centralized economic power in the hands of C.D. Howe. Howe believed fervently that Canada always needed a grand project, on par with the CPR, to spur development. In this, he was a traditional mercantilist.

His first grand project was a state-owned airline. In 1935, Howe became Transportation Minister, immediately squashed a nascent private-sector airline, organized Trans Canada Airlines (TCA, later renamed Air Canada) as a subsidiary of the state-owned Canadian National Railway; and hand picked all its senior managers. He supervised the construction of the Trans-Canada Highway. A series of nation building exercises ranged from massive construction projects to subsidies for 'strategic industries' like jet fighter building. For example, in the 1950s, Howe subsidized aircraft manufacturers A.V. Roe (Avroe), Canadair, and De Havilland. Howe also used subsidies to prop up depressed regions. For example, he directed an increasing flow of subsidies to Dominion Steel and Coal in northern Nova Scotia.

\footnotetext{
${ }^{70}$ Bliss (1986) p. 368.

${ }^{71}$ See McKay (1983).

${ }^{72}$ Bliss (1986), p. 371.
} 
But Howe also sought to control all business-government relations through his office, and this was new. After running the wartime planned economy, Howe held a rotating portfolio of cabinet positions, with economic power following him from office to office. Howe sought to steer the economy however he could. He granted or denied import permits on a case-by-case basis, favoring some firms over others. High taxes were now institutionalized, and Howe quickly realized that the tax system was now his major tool for micromanaging the economy.

Canadian business was still in the hands of a small network connected by ethnicity, school ties, and family connections; and by the war's end, Howe had a personal relationship with every member of that network. Corporate presidents routinely asked Howe to recommend bureaucrats for corporate management jobs. Years later, the top executives of the country's biggest firms owed their careers to Howe. Howe invested heavily in the stocks of such companies, and his policies often greatly affected their profits. For example, James Dunn, the CEO of Algoma Steel, called Howe, whose policies saved the company and who (through a trust) was a major investor, the "great white father in Ottawa". ${ }^{73}$ The recipient of major government contracts, CD Howe \& Co. was run by Howe's son and son-in-law.

In 1956, with subsidized construction of the St. Lawrence Seaway nearing completion, Howe chose a transcontinental oil pipeline as his next grand project. The "dictator" pushed enabling legislation through parliament, invoking closure from the outset to end debate, and then wielded his war powers to organize its construction by American oil companies. Howe won the pipeline debate, but the Liberals, since 1948 led by Louis St. Laurent, lost the 1957 election because of it. C.D. Howe lost his seat to a socialist schoolteacher. Apart from his infatuation with grand nation-building projects, and the contracts associated with them, Howe largely left the economy to the invisible hand. By concentrating businessgovernment relationships in his office, Howe professionalized the civil service and forced other politicians to get by without wielding such influence.

The new Progressive Conservative Prime Minister, John Diefenbaker (1957-63), an upstart lawyer born in a shack in rural Saskatchewan, inherited Howe's nation building schemes. The dearest was A.V. Roe Co., which now produced an ill-designed jet fighter called the Avro Arrow. ${ }^{74}$ Roe allegedly used A.V. Roe's cost-plus government financing to build a pyramid of engine makers, steel firms, and railway car builders, and finally to acquire DOSCO, a pyramid of steel and coal companies. ${ }^{75}$ Diefenbaker cut its subsidies in 1957, at the onset of the so-called Diefenbaker Recession.

With Howe gone, nation building seemed almost passé. However, Canada's mercantilist heritage could not long be suppressed. Its noisiest eruption was in Québec. La Révolution tranquille of the early 1960s marginalized the Roman Catholic hierarchy, opening the public mind to increasingly radical ideas - first secular education and divorce, then socialism, and finally separatism. Québec subsidized a new steel industry, built vast hydroelectric projects, and supported gigantic aluminum smelting ventures. Its most intrepid venture was the Caisse de Dépôt et Placement du Québec, which began buying control blocks of listed firms in 1967. The Caisse was to be government controlled pyramidal group, a much cheaper way to take charge of the economy than outright nationalizations, and more effective than regulation. Many of the firms the Caisse took over were previously widely held.

Partly to deflect Québec separatism, the Trudeau Liberals trumpeted Canadian nationalism. Trudeau disliked economics, and delegated economic policy to his college chum Marc Lalonde, a committed nationalist who aspired to replace American dominance of the economy with links to Europe and Japan. This philosophy acquired more force between 1972 and 1974 when a Trudeau minority government depended on the socialist, and now highly nationalist, New Democratic Party. Tories, especially those of Loyalist lineage, joined the anti-American cries.

Although patriotism, ideology, and history certainly kindled this wave of nationalism, it quickly acquired a mercantilist hue. Canadian executives feared US takeovers as career disasters, and old families feared foreign competition. In this setting, successive Trudeau governments constructed an alphabet soup of government agencies to subsidize "Canadian" firms, vet foreign takeovers, and control ownership structures explicitly in "strategic" industries like culture and energy.

\footnotetext{
${ }^{73}$ Quoted by Bliss (1986), p. 472.

${ }^{74}$ The company also received subsidies from the US Defense Department to produce the Avrocar, a small flying saucer.

${ }^{75}$ See Bliss (1986, p. 475) for details.
} 
Publishing companies, like the Southam group and Maclean-Hunter, lobbied strenuously for foreign content rules to drive US competitors, like Time and the Wall Street Journal, out of Canada. Canadian filmmakers lobbied successfully for generous tax subsidies in the name of Canadian culture. The Canadian Radio and Television Commission (CRTC) mandated that Canadian-made programs constitute set fractions of broadcasting schedules, and licensed entry into broadcasting to create profit cushions to finance this programming. The regulation, cartelization, subsidization, and protection of "cultural industries" became national policy.

Canadian content regulations did succeed in relocating substantial parts of United States program and film production to Canada; for "cultural products" are "Canadian" if they are partially produced in Canada. Thus, many US network programs and films now count as "Canadian culture". ${ }^{76}$ Television content regulations also made Canada a world leader in cable television technology, as Canadians subscribed in droves to receive foreign stations.

In 1971, the Liberals set up the Canada Development Corporation (CDC) as a "white knight" to block takeovers by foreign firms. In 1973, they established the Foreign Investment Review Agency (FIRA) to vet foreign takeovers. FIRA took its work seriously, and began blocking foreign takeovers with considerable energy. A spike of takeover activity in the early 1970s corresponds to multinationals exiting and selling their operations either to state organs or to private sector Canadian firms.

The acme of Trudeau era mercantilism was the National Energy Policy (NEP) - enacted in 1981. All current and future energy prices were legislatively set, and preannounced in 1981, cutting the profits of existing energy firms sharply. Up to $80 \%$ of drilling costs in Federal Territories (the arctic) would be paid by the government, but only if the drilling company was at least $75 \%$ Canadian owned. Less than 50\% Canadian ownership disqualified a company entirely from operating in Federal Territories. These provisions were designed to discriminate against foreign-controlled companies and to lessen Alberta's importance by damping its economy and developing oil and gas in the arctic, where the federal government owned the mineral rights. The most controversial element of the NEP was the direct expropriation of twenty-five percent of the properties of all foreign controlled companies already active in Federal Territories. These properties were reassigned either to PetroCanada, the new federally owned oil company, or to other government organs. PetroCanada was also to buy foreign-controlled oil companies with money from a new Canadian Ownership Account (CAO), to be financed with a new federal tax.

The government began nationalizing industrial firms, including De Havilland Aircraft, Westcoast Energy, and many others. Air Canada acquired private airlines, and other state-owned enterprises expanded. State ownership, control, and regulation were dominating the land almost as during the war.

Businesses either learned to navigate the new environment or floundered. Swatsky (1987) writes that business leaders "yearned for the not so distant time when they could phone C.D. Howe and resolve their problems on the spot." Prior to Howe, self-interested politicians routinely and overtly undertook joint ventures with business leaders, and these "business government partnerships" enriched both. Howe professionalized the civil service, and insulated it from political pressures - other than his own. With the economy liberalized and Howe gone, business leaders continued to lunch with politicians, but the urgency of such meetings faded as the government withdrew its hand from the economy.

Now suddenly, the Trudeau government's hand was visible everywhere, and there was no longer a single point of contact for business. Numerous agencies, offices, and authorities now took part in regulating the economy. The Trudeau era federal government was large and complicated, with interconnected lines of control that did justice to the most complicated corporate pyramids. Increasingly estranged from this new public sector, business leaders were repeatedly hit with regulations, laws and decisions that seemed from out of the blue.

Swatsky (1987) describes how some of the most brilliant young Canadians of the 1970s came to realize that "business was fundamentally incompetent in dealing with government" and that the increasing complexity of government created golden business opportunities. These young entrepreneurs built a new industry of consulting firms to monitor government, alert clients about impending problems, coach them about how to deal with different government organs, and to intervene on their clients' behalf. The value of these interlocutors became increasingly evident. Swatsky (1987, p.98) recounts how a multinational consortium invested $\$ 150$ million dollars in an application to build a natural gas pipeline along the

\footnotetext{
${ }^{76}$ See Atcheson and Maule (1999).
} 
Mackenzie valley and then lost out to a hastily conceived, ill-prepared, and under-financed rival through "bad lobbying". The business of helping business deal with government grew in leaps and bounds, creating a new troop of millionaires.

Companies that learned to build their strategies around government policies prospered. Nova, a new widely held pyramidal group grew rapidly through a spate of takeovers, cheered on by the supervisors of the NEP as it "Canadianized" firm after firm. While most oil and gas companies railed against the NEP, Nova learned to love it. Of course, the firm was also buttressed by its legislatively protected cost-plus natural gas transmission monopoly. Dome Petroleum also earned laurels from the NEP for its purchase of Conoco in a complicated takeover deal involving Mesa and Occidental Petroleum.

Although most of the federal government's Trudeau era corporate acquisitions were of formerly foreign controlled firms, provincial governments - especially Quebec, were less fussy. The separatist Parti Québecois, now running the province, took its economic ideology from France, and directed its vast state controlled pyramidal group, the Caisse de Dépôt et Placement du Québec, to acquire control blocks in Dominion Textile, the former Argus company Domtar Inc., and many other firms.

In 1984, Brian Mulroney routed the Liberals, and his Progressive Conservatives dismantled or defanged many Trudeau era industrial policy agencies and ownership restrictions. Mulroney also embarked on a privatization program, floating Howe's Air Canada, Borden's Canadian National Railway, Trudeau's PetroCanada, and a host of other state-owned enterprises as freestanding widely held firms. Free trade with the United States, enacted in 1989, greatly reduced the returns to rent-seeking for preferential tariffs. Exposés of improprieties in the Caisse undermined Québec's industrial policy, and other provincial governments began selling off their state-owned enterprises too. ${ }^{77}$ However, subsidies to politically powerful industries, like autos and aerospace, continued, as did funds for regional development, especially in Atlantic Canada. Corporate taxes remained a Byzantine maze of implicit subsidies and regulatory bureaucracies remained powerful. Patronage appointments remained a staple in the political diet.

In 1993, Jean Chrétien led the Liberals back into power. More interventionist than the Mulroney Tories, they reinvigorated the rules and regulations protecting "cultural industries". Now the Liberals were divided between those of the Trudeau era and those who looked back to Laurier for inspiration, but continued subsidies, regulations, and industrial policies won the day. The Mulroney and Chrétien regimes were also both plagued by allegations of kickbacks, cronyism, and misappropriation of public funds. ${ }^{78}$ However, in fairness, government was much more transparent, the press more aggressive, and the populace less accepting than in the past. The allegations against the Mulroney Tories are small change, and those against the Chrétien Liberals, though more substantial, remains unproved.

An explanation of ownership structure with differential success at rent seeking thus must go as follows: The first decade of the $20^{\text {th }}$ century was probably a period of rising mercantilist expectations, and family groups grew in importance in Laurier's last years. Influencing government was not terribly useful early in the Laurier years, but this apparently changed in his last term. The cartels of the 1930s, though state enforced, were administered by industry association, not the government. And though business government relations were close during the Second World War, political rent-seeking was probably constrained by patriotism, or at least the fear of being branded a profiteer. Family groups gave ground to widely held firms from the 1920s through to the 1950s. In the 1950s, Howe continued to intervene in the economy, but monopolized business-government relationships. Shleifer and Vishny (1993) argue that monopolistic corruption is much less expensive to firms than decentralized corruption. A similar argument may apply for legal political rent-seeking. By centralizing rent seeking in his office, Howe perhaps reduced the benefits of being a superior rent-seeker. In the 1960s, Diefenbaker and then Pearson cut back on subsidies to industry, presumably keeping the benefits of superior rent seeking ability low. Trudeau returned to large-scale intervention, and the benefits of superior rent-seeking soared, giving pyramidal groups a decided advantage. This accounts for their upswing in the last third of the century.

\footnotetext{
${ }^{77}$ See Arbour (1993) for a detailed history of the Caisse.

${ }^{78}$ See Cameron (1994) for allegations of corruption in the Mulroney governments, and the Auditor General's 2004 Report to Parliament for evidence of corruption under Chrétien.
} 


\section{Ethnic Divisions}

Easterly and Levine (1997) show that greater ethnic divisions slow growth in modern African emerging economies. This reflects lower public expenditure on schools, worse political instability, larger government deficits, weaker financial systems, more distorted foreign exchange, and less infrastructure investment in general. They argue that all of these problems reflect different ethnic groups fighting to divert public revenues toward themselves and away from other groups.

There is no evidence that ethnic tensions cause problems of similar magnitudes in developed economies. However, Canada's French-English linguistic divide is an ongoing source of political and economic crises. Québec's Révolution tranquille of the 1960s brought long dormant linguistic grievances to the surface, ultimately leading to Québec separatism. Canadian politics focused on uniting Canada's linguistic solitudes thenceforth. One of Canada's greatest financial crisis of the last half century occurred in 1976 when the separatist Partie Québécois won power. The Canadian dollar, previously trading above the United States dollar, plummeted and never recovered. The motive of the Québec government in building up its own pyramidal group, the Caisse de Dépôt et Placement du Québec, was certainly to inject Francophone control into the corporate sector, though a European socialist perspective was clearly at work too. The motive of the Trudeau Liberals in building their vast system of subsidies, taxes, and regulations through the 1970s and 1980s was overtly nationalist - to forge a Canadian identity to supersede English or French Canadian identities, much as Bismarck did in $19^{\text {th }}$ century Germany. But again, a socialist economic philosophy may have been more important.

This line of reasoning is certainly the most speculative we advance, and we do so cautiously. Canadians are highly educated and it seems unlikely that tribal loyalties could so unbalance the nation as to affect its institutions and the control of its great corporations. There is most likely a coincidence of timing, and at most a marginal effect worsening slightly a relapse into mercantilism.

\section{Openness}

Canada entered the $20^{\text {th }}$ century protected by the high tariffs of MacDonald's National Policy, in place since 1879. Wilfrid Laurier's Liberals, disposed to free trade, had to promise loudly and repeatedly not to touch the National Policy to gain business support in their campaigns. When they finally let principles prevail over prudence, in the 1911 election, they lost handily.

High tariffs remained in place through the 1920s, but Canadian exporters penetrated deeply into the US market in certain sectors. Abe and Harry Bronfman, who ran hotels in western Canada, discovered the highly profitable mail order liquor business. His attention to quality and cost soon made Harry the biggest liquor wholesaler in Saskatchewan, with most of his business in border towns. By 1927, having gained control of Seagram's, an old family distillery in Ontario, the Bronfmans were among the richest families in Canada. The Ontario hotelier Harry Hatch took over Gooderheim and Hiram Walker distilleries, and set up a rival mail order and wholesale liquor business. The stalwartly devout Labatt family turned over management of their breweries to Edmund Burke, an Irish catholic who cheerfully maximized exports. By the mid 1920s, competition in beer and spirits exports was so intense that profits were dangerously thin and Canadian exporters organized to fix prices.

All of these enterprises owed a deep debt to the Molson family, who vigorously worked their political connections to keep Canada, and especially Québec, from succumbing to the hysteria of Prohibition - America's "War on Alcohol". Since American shippers, like Al Capone, handled customs formalities, tariffs were not an impediment to trade.

But other Canadian industries were in worse shape by the end of the 1920s. Worldwide overcapacity in minerals, paper, wheat, and manufactured goods depressed prices. In 1930, the United States enacted the Smoot Hawley Act - high tariffs that crippled Canada's exports. Industry after industry crumpled, hiring stopped and layoffs started. Prime Minister Bennett's solution was to raise the tariff to protect industry association cartels committed to keeping prices high.

At the Ottawa Imperial Economic Conference of 1932, Bennett orchestrated an Empire-wide retaliation to US tariffs. The new Imperial Preferences abruptly shut United States and Baltic lumber and paper out of Imperial markets, resurrecting the British Columbia industry. Canada Packers could now undercut Danish pork producers, and U.S. firms had to establish branch plants in Canada to re-enter Imperial markets. 
In the late 1940s, Howe argued for a final elimination of the National Policy, and Prime Minister King negotiated a free trade treaty with the United States. But, apparently reflecting on Laurier's 1911 defeat, King quietly discarded the plan.

Trade barriers only started falling with the General Agreement on Tariffs and Trade -rounds of negotiation and multilateral treaties after World War II. However, multilateral negotiations were, from a pragmatic viewpoint, less important than regional trade barriers, especially those between Canada and the United States. Prime Minister Pearson ultimately negotiated an Auto Pact with the United States in 1965 that permitted free trade in automobiles and auto parts. The pact also contained useful market share provisions for Canadian manufacturers. The Auto Pact transformed a dying industry into an engine of the Ontario economy, and would serve as a blueprint for subsequent negotiations to reduce trade barriers in other industries.

Further multilateral and industry arrangements steadily lowered trade barriers between Canada and the United States through to the 1980s, when the bureaucratic hassle at the border was often a larger cost than the actual remaining tariffs. The Mulroney Tories therefore negotiated a comprehensive Free Trade Agreement (FTA) with the United States to abolish all remaining trade barriers. After winning a majority government in a snap election called to gain a mandate for the agreement, the Tories enacted the FTA in 1989. The agreement removed remaining trade barriers, industry by industry, over a ten year period. Tariffs on motorcycles and computers disappeared the first year, excluding only cultural industries (at the insistence of the Canadians), defense industries (at the insistence of the Americans), and agriculture and textiles (at the insistence of both). ${ }^{79}$

Thus trade barriers were high and rising through the first half of the century, as widely held freestanding firms grew predominant, and then fell in the second half of the century as family groups reasserted their supremacy. Although the timing is not exact, Figures 6 and 7, might be interpreted as suggesting that freestanding widely held firms do better in economies protected by trade barriers. However, other evidence makes this unlikely. Morck et al. (2000) find that the stock prices of Canadian firms controlled by old money families dropped relative to other firms in their industries upon the surprise victory of the Mulroney Tories in the election called on free trade. Rajan and Zingales (2003) argue that many countries possessed better developed financial systems a century ago than now, and that unconstrained elites undermined these systems later in the century to deprive upstart competitors of capital. They find that this less in countries more open to the global economy - suggesting that openness averts concentrated corporate control by a narrow elite. They emphasize openness in both goods and capital markets.

Openness to foreign capital need not always accompany trade openness, so before forsaking openness as an explanation of changes in ownership structure, we explore the history of openness to global capital markets.

Prior to World War I, Canada was on the gold standard and fully open to foreign capital. The Great War interrupted the flow of British capital, as well as most transatlantic shipping, and immigration. Canada returned to the gold standard after the war, and foreign capital again flowed in during the 1920s, this time from New York more than London.

In the 1930s, Bennett abandoned the gold standard as he raised tariffs, but Canada remained open to foreign capital under the post World War II Breton Woods system and after it.

The substitution of American for British capital, first visible in the 1920s, was now complete. In the 1960s and especially the 1960s, American capital flowed into Alberta oil and gas firms, fueling the regions rapid growth. Though Safarian (1969) and others show this capital flow beneficial, high profile takeovers, like Gulf's acquisition of British American Oil, irked nationalists and probably scared corporate insiders, who feared losing out in takeovers. American ownership became more controversial than the foreign capital inflows overseen by Laurier or King. Imperialists saw increasing United States influence undermining ties to Britain. Socialists, nationalists, and old fashioned conservatives gained media attention condemning United States multinational corporations for any number on sins. Some top managers at widely held firms and old family patriarchs surprised the socialists by chiming in with unexpected support.

\footnotetext{
${ }^{79}$ With no major changes as regards United States-Canada trade, the FTA was extended to Mexico and rechristened the North American Free Trade Area (NAFTA).
} 
Diefenbaker, the prairie lawyer, was unimpressed by all of this. An outsider to the Anglo corporate elite, he was disinclined to interfere in the market for corporate control. The farthest he went was to permit defensive tactics like the mutulaization of the largest insurance companies, including Canada Life, Confederation, Equitable Life, Manufacturers, and Sun. This allowed their delisting, and so blocked takeovers (not just foreign ones) and ensconced their top managers.

Howe had angered nationalists by turning construction of his pipeline over to Americans. Then Diefenbaker infuriated them by canceling the Arvro Arrow. That fury contributed to his loss of the 1962 election, which returned the Liberals to power under Lester Pearson. An old guard rebellion within the Tory Party forced Diefenbaker out as opposition leader a few years later. However, the Pearson Liberals avoided protectionist policies for the most part. An early exception set this tone. In 1963, the Liberal Finance Minister, Walter Gordon, announced a 30\% takeover tax on the sale of publicly traded companies to foreigners. Amid a storm of controversy, the tax was hurriedly withdrawn.

The Liberals sought to campaign from the left and rule from the center, but their explicit embrace of economic nationalism exposed them to charges of hypocrisy. When the takeover of a small bank by US interests triggered more nationalist outcry, the Liberals responded in 1964 by legislating voting caps on the big banks. These forbade any single shareholder from holding more than a ten percent stake, and capped aggregate foreign ownership at twenty-five percent. Both restrictions were enshrined in the 1967 revision to the Bank Act. Garvey and Giamarino (1998) conclude that these restrictions "were put in place to prevent American ownership of Canadian banks and there is little indication that consideration of economic costs played a significant role in the decision."

The other major economic initiative of the Pearson Liberals was a half step in the opposite direction. The 1965 Auto Pact paved the way for vast United States investment in the Ontario auto sector, and paved the way for the FTA in 1989.

Foreign direct investment form the United States became one of the highest profile evils to be fought by successive Trudeau governments from the late 1960s through the mid 1980s. Their Canada Development Corporation (CDC) was a "white knight" to block foreign takeovers, their Foreign Investment Review Agency (FIRA) had the legislative power to block foreign takeovers, and their National Energy Policy (NEP) established unfavorable tax and subsidy rules for foreign controlled companies. The Canada Radio and Television Commission (CRTC) and other government organs blocked, taxed, and regulated foreign investment in 'cultural' industries.

The inflow of foreign capital to Canada was thus unrestricted through most of the century, except for the abandonment of the gold standard during the First World War and the Great Depression. However, foreign capital inflow was highly regulated and discouraged with various tax and subsidy provisions under the Trudeau governments. The rise of widely held firms corresponds to capital account convertibility, their decline to capital account restrictions. How the two might be connected is unclear, but there are several possibilities.

The Trudeau governments wielded greater and more wide-ranging economic power than any previous government, with the possible exception of King's wartime administration. They also sought to stop American takeovers of Canadian firms, but were constrained by revenue shortfalls, which they could not relaxed much further through loose monetary policy because of growing public discontent with inflation. It is conceivable that Trudeau era officials might have rewarded Canadian business families that took control blocks in widely held firms, and so saved them from possible foreign takeovers. Globerman (1984) argues that Trudeau era restrictions on foreign takeovers created rents for Canadian families, as they were better able to disguise payoffs for running such nationalist errands than freestanding listed firms. However, no government records attest to such dealings, so this explanation remains highly hypothetical.

The FIRA publicized its high approval rates on FDI reviews, but Globerman (1984) correctly argues that foreign investors likely to be turned down did not apply. Moreover, the approvals were often contingent on agreements to source from Canadian firms, undertake other investments, and so on. Globerman argues that such restrictions are, in essence, transfers from foreign investors to favored Canadian firms. The government might have used such restrictions, among its other economic powers, to reward firms that helped advance its Canadian control agenda. The NEP formalized this, granting explicit tax breaks and subsidies to reward Canadian acquirers of control blocks in previously foreign controlled 
energy. However, outside the energy and cultural industries, formal arrangements like this are not evident, and the hypothesis cannot be confirmed.

$\mathrm{He}$ also argues that the Trudeau era barriers, discriminatory subsidies, and tax penalties against foreign investment may have had another unintended effect. Canadian entrepreneurs may build companies with a view to selling them eventually to larger concerns and retiring or starting other new ventures. These firms might be sold to public shareholders, and become widely held, or sold to existing firms. By constricting the pool of potential buyers to Canadians and favored foreigners, the Trudeau governments probably reduced this ultimate payoff to entrepreneurship. This could have deterred new firms from forming. Not formed, they never became large freestanding widely held corporations.

\section{Conclusions}

Recent work, including La Porta et al. (1997, 1997a, 1998, 1999, 2000, 2000a), Acemoglu et al. (2000, 2001, 2002, 2003), and others stresses the importance of legal system origins and distant colonial conditions in constraining the evolution of modern institutions. We provide a detailed case study of how this occurs. Canada's institutions of both government and business have deep mercantilist roots, stretching back to colonial times. Those roots nourish modern developments and ideologies, transforming them to direct institutional development down mercantilist paths.

Khanna and Palepu $(1997,2000,2001)$ argue that family controlled business groups have a survival advantage over freestanding widely held firms in India and other developing countries because group firms can deal with each other, avoiding transactions in corrupt or otherwise flawed open markets. Consistent with newly industrialized Canada having weak institutions supporting its markets, most large Canadian companies belonged to business groups at the beginning of the century. Canada's early industrialization also provides insights into the general validity of many current theories of economic growth. This period of Canada's development is consistent with Acemoglu et al. (2000, 2003), Murphy et al. (1989), Solokoff and Engerman's (2000), and others.

The early and mid-twentieth century were periods of ascendant economic liberalism, featuring a well developed stock market, solidified shareholder rights, increasing competition, and a shrinking role of government. These events all favored the profusion of large freestanding wide held firms, consistent with La Porta et al. (1999) and Burkart et al. (2002).

Events in the latter decades of the century encouraged government intervention in the economy for laudable political reasons and high ideals. However, Canada's mercantilist roots, never fully eradicated, but kept alive thought successions of elites, found this expanded public sector fertile ground. Soon, socially progressive institutional innovation became a thicket of complicated subsidies, transfers, tax advantages, and regulation that stimulated vast corporate investments in political influence. Morck and Yeung (2004) argue that family controlled corporate groups are more effective political rent seekers than freestanding widely held firms. Consistent with this, the final decades of the century saw a marked resurgence of corporate groups. Labor rights were also strengthened substantially later in the century, so Roe's (2003) theory that concentrated ownership arises to counter strong labor unions has some traction regarding the fall of the widely held firm after the 1960s, but not their rise over the first half of the century

Our findings are consistent with previous work in this area, including Rajan and Zingales (2003) who argue that entrenched elites in many countries acquiesce to or promote policies that erode financial systems, Olsen $(1963,1982)$ who describes the behavior of entrenched elites, and others, like Baumol (1990) and Kruger (1974), who advance theories of rent seeking. 


\section{References}

Acemoglu, Daron and James A. Robinson. 2000. Economic Backwardness in Historical Perspective. National Bureau of Economic Research working paper 8831.

Acemoglu, Daron, Simon Johnson, and James A. Robinson. 2001. "The Colonial Origins of Comparative Development: An Empirical Investigation," American Economics Review 91(5): 1369 - 1401.

Acemoglu, Daron, Simon Johnson, and James A. Robinson. 2002. "Reversal of Fortune: Geography and Institutions in the Making of the Modern World Income Distribution," Quarterly Journal of Economics 117(4): 1231-94.

Acemoglu, Daron, Simon Johnson, and James A. Robinson. 2003. "Understanding Prosperity and Poverty: Geography, Institutions and the Reversal of Fortune," mimeo, MIT (Feb. 20, 2003).

Acheson, Keith and Christopher Maule. 1999. Much Ado about Culture - North American Trade Disputes. University of Michigan Press.

Agnblad, Jonas, Erik Berglöf, Peter Högfeldt and Helena Svancar. 2001. "Ownership and Control in Sweden: Strong Owners, Weak Minorities and Social Control." In Barca, Fabrizio and Marco Becht, eds. The Control of Corporate Europe. European Corporate Governance Network, Oxford University Press.

Almeida, Heitor and Daniel Wolfenzon. 2003. A Theory of Pyramidal Ownership and Family Business Groups. Stern NYU Working paper

Arbour, Pierre. 1993. Québec Inc. and the Temptation of State Capitalism-Québec's Caisse de Dépôt et Placement du Dépôt and State-Owned Corporations: What Legacy for a New Generation? Robert Davies Publishing, Montreal.

Armstrong, Christopher and H.V. Nelles. 1986. Monopoly's Moment - The Organization and Regulation of Canadian Utilities, 1830-1930. Temple University Press.

Armstrong, Christopher. 1986. Moose Pastures and Mergers: The Ontario Securities Commission and the Regulation of Share markets in Canada, 1940 - 1980. University of Toronto Press.

Armstrong, Christopher. 1997. Blue Skies and boiler Rooms - Buying and Selling Securities in Canada, 1870-1940. University of Toronto Press.

Atcheson, Keith and Christopher Maule. 1999. Much Ado about Culture. University of Michigan Press.

Attig, Najah, Yoser Gadhoum, and Larry Lang. 2002. "Bid-Ask Spread, Asymmetric Information and Ultimate Ownership." Working paper. Chinese University of Hong Kong.

Bae, Kee-Hong, Jun-Koo Kang and Jin-Mo Kim. 2002. "Evidence from Mergers by Korean Business Groups: Tunneling or Value Added?" Journal of Finance, forthcoming.

Barclay, Michael, and Clifford Holderness. 1989. "Private benefits from control of corporations." Journal of Financial Economics 25, 371-395.

Barclay, Michael, Clifford Holderness, and Jeffery Pontiff. 1993. "Private benefits from block ownership and discounts on closed-end funds," Journal of Financial Economics 33, 263-291.

Baskerville, Peter. 1987. The Bank of Upper Canada. Carleton University Press.

Baumol, William J. 1990. "Entrepreneurship: Productive, Unproductive, and Destructive," Journal of Political Economy 98, 893-921.

Bebchuk, Lucien, Reinier Kraakman, and George Triantis. 2000. "Stock Pyramids, Cross Ownership and Dual Class equity: The Mechanisms Aand Agency Costs of Separating Control from Cash Flow Rights.” In R. Morck ed. Concentrated Corporate Ownership. National Bureau of Economic Research Conference Volume. University of Chicago Press.

Becht, Marco and Ekkehart Böhmer. 2001. "Ownership and Voting Power in Germany." In Barca, Fabrizio and Marco Becht, eds. The Control of Corporate Europe. European Corporate Governance Network, Oxford University Press.

Becht, Marco, Ariane Chapelle, and Luc Renneboog. 2001. "Shareholding Cascades: The Separation of Ownership and Control in Belgium." In Barca, Fabrizio and Marco Becht, eds. The Control of Corporate Europe. European Corporate Governance Network, Oxford University Press.

Beck, Thorsten and Ross Levine. 2002. Industry growth and capital allocation: Does having a market- or bank-based system matter? Journal of Financial Economics 64(2) 147.

Bertrand, Marianne, Paras Mehta, and Sendhil Mullainathan. 2002. "Ferreting out tunneling: An application to Indian business groups," Quarterly Journal of Economics 117(1): 121-148. 
Bhagwati, Jagdesh. 1998. The Capital Myth: The Difference Between Trade in Widgets and Trade in Dollars. Foreign Affairs 77(3) 7-12.

Bianchi, Marcello, Magda Bianco and Luca Enriques. 2001. "Pyramidal Groups and the Separation Between Ownership and Control in Italy." In Barca, Fabrizio and Marco Becht, eds. The Control of Corporate Europe. European Corporate Governance Network, Oxford University Press.

Bliss, Michael. 1986. Northern Enterprise - Five Centuries of Canadian Business. McClelland and Stewart. Toronto.

Bloch, Laurence and Elizabeth Kremp. 2001. "Ownership and Voting Power in France." In Barca, Fabrizio and Marco Becht, eds. The Control of Corporate Europe. European Corporate Governance Network, Oxford University Press.

Boothman, Barry. 2000. "High Finance/Low Strategy: Corporate Collapse in the Canadian Pulp and Paper Industry, 1919 to 1932," Business History Review 74 (winter), 611-56.

Bris, Arturo. 2003. Do Insider Trading Laws Work. Yale University working paper.

Browde, Anatole. 2002. "Settling the Canadian Colonies: A Comparison of two Nineteenth Century land Companies," Business History Review 76, Summer, 299-335.

Bryce, George. 1935. The Scotsman in Canada. Quintin publications.

Burkart, Mike, Fausto Panunzi and Andrei Shleifer. 2002. "Family Firms." NBER Working Paper 8776.

Cameron, Steve. 1994. On the Take - Crime, Corruption, and greed in the Mulroney Years. Macfarlane, Walter and Ross: Toronto.

Claessens Stijn, Simeon Djankov, Larry H.P. Lang. 2000. "The separation of ownership and control in East Asian Corporations," Journal of Financial Economics 58(1-2): 81-112.

Claessens, Stjin, Simeon Djankov, Joseph Fan, and Larry Lang. 2002. "Expropriation of minority shareholders in East Asia," Journal of Finance, forthcoming.

Crespí-Cladera, Rafel and Miguel García-Cestona. 2001. "Ownership and Control of Spanish Listed Firms." In Barca, Fabrizio and Marco Becht, eds. The Control of Corporate Europe. European Corporate Governance Network, Oxford University Press.

Daniels, Ron, Randall Morck and David Stangeland. 1995. High Gear: A Case Study of the Hees-Edper Corporate Group. In R. Daniels and R. Morck, eds. Corporate Decision Making in Canada. Industry Canada and the University of Calgary Press. Calgary.

De Jong, Abe, Rezaul Kabir, Teye Marra, and Ailsa Röell. 2001. "Ownership and Control in the Netherlands." In Barca, Fabrizio and Marco Becht, eds. The Control of Corporate Europe. European Corporate Governance Network, Oxford University Press.

Demsetz, Harold and Keneth Lehn. 1985. "The Structure of Corporate ownership: Causes and Consequences," Journal of Political Economy 93, 1155-77.

Dorin, Patrick. 1988. The Canadian National Railway. Superior Publishing: Toronto.

Dowde, 2002.

Dyck, Alexander and Luigi Zingales. 2001. Why Are Private Benefits of Control so Large in Certain Countries and What Effects Does This Have on Their Financial Development? Unpublished manuscript.

Easterly, William and Ross Levine. 1997. "Africa's growth tragedy: Policies and ethnic divisions," Quarterly Journal of Economics 112(4): 1203-51.

Easterly, William. 2002. "Inequality does cause underdevelopment: New Evidence from Commodity Endowments, Middle Class Share, and Other Determinants of Per Capita Income," NYU working paper.

Engerman, Stanley and Kenneth Sokoloff. 1997. "Factor Endowments, Institutions, and Differential Paths of Growth Among New World Economies: a View from Economic Historians of the United States," in How Latin America Fell Behind. Stephen Haber, ed. Stanford University Press.

Faccio, Mara. 2003. Politically Connected Firms - Can They Squeeze the State? University of Notre Dame working paper.

Fauteux 1927.

Francis, Diane. 1988. Contrepreneurs. Macmillan Canada.

Francis, Dianne. 1986. Controlling Interests: Who Owns Canada? Macmillan of Canada, Toronto. 
Garvey, Gerald and Ron Giammarino. 1998. Ownership Restrictions and the Value of Canadian Bank Stocks. University of British Columbia Research Paper Prepared for the Task Force on the Future of the Canadian Financial Services Sector

Glaeser, Edward L and Andrei Shleifer. 2002. "Legal Origins," Quarterly Journal of Economics 117(4): 1193.

Globerman, Steven. 1977. Mergers and Acquisitions in Canada: A background report for the Royal Commission on Corporate Concentration. Government of Canada.

Globerman, Steven. 1984. "Canada's Foreign investment Review Agency and the Direct Investment Process in Canada," Canadian Public Administration 27(3): 313-328.

Gulgler, Klaus, Susanne Kalss, Alex Stomper, and Joseph Zechner. 2001. "The Separation of Ownership and Control in Austria." In Barca, Fabrizio and Marco Becht, eds. The Control of Corporate Europe. European Corporate Governance Network, Oxford University Press.

Haber, Stephen. 2002. Crony Capitalism and Economic Growth in Latin America - Theory and Evidence. Hoover Press, Stanford University.

Hedley, James, ed. 1894. Canada and Her Commerce - A Souvenir of the Dominion Commercial Traveller's Association. Sabiston Litho. \& Pub. Co. Montreal.

Henry, Peter Blair. 2000. Do stock market liberalizations cause investment booms? Journal of Financial Economics 58(1-2) 301-334.

Henry, Peter Blair. 2000a. Stock market liberalization, economic reform, and emerging market equity prices. Journal of Finance 55(2) 529-65.

Irwin, Douglas. 2002. "Interpreting the tariff-growth correlation of the late 19th century," American Economic Review 92(2): 165-169.

Jensen, Michael and William Meckling 1976. The Theory of the Firm: Managerial Behavior, Agency Costs and Ownership Structure. Journal of Financial Economics. 3 305-360.

Johnson, Simon, Rafael La Porta, Florencio Lopez-de-Silanes, and Andrei Shleifer. 2000. "Tunneling," American Economic Review, May, 90(2): 22-27.

Johnson, W. Bruce, Robert P. Magee, Nandu J. Nagarajan and Henry A. Newman. 1985. "An Analysis of the Stock Price Reaction to Sudden Executive Deaths: Implications for the Management Labor Model," Journal of Accounting and Economics, April, 7(1-3): 151-174.

Khanna, T. and K. Palepu. 1997. "Why Focused Strategies May be Wrong for Emerging Markets," Harvard Business Review, July-August.

Khanna, Tarun and Krishna Palepu. 2000. "Is group affiliation profitable in emerging markets? An analysis of diversified Indian business groups," Journal of Finance, April, 55(2): 867-93. Formerly titled "Corporate Strategy and Institutional Context: An Empirical Analysis of Diversified Indian Business Groups,” Harvard Business School Working Paper \#96-051.

Khanna, Tarun and Krishna Palepu. 2001. "Emerging Market Business Groups, Foreign Investors, and Corporate Governance." In R. Morck ed. Concentrated Corporate Ownership. National Bureau of Economic Research Conference Volume. University of Chicago Press.

Khanna, Tarun and Krishna Palepu. 2002. "The Future of Business Groups in Emerging Markets: Long Run Evidence from Chile," Academy of Management Journal, forthcoming. Harvard Business School Working Paper \#99-077.

Khanna, Tarun. 2002a. "Business Groups and Social Welfare in Emerging Markets: Existing Evidence and Unanswered Questions," European Economic Review, 44(5), 748-761

Khemani, R.S., D.M. Shapiro, and W.T. Stanbury. 1988. Mergers, Corporate Concentration, and Power in Canada. Institute for Research and Public Policy, Halifax.

King, Robert and Ross Levine, 1993. "Finance and Growth: Schumpeter Might Be Right," Quarterly Journal of Economics 108(3): 717-737.

Krueger, Anne. 1974. "The Political Economy of the Rent-Seeking Society," American Economic Review 64, June, 291-303.

Kryzanowski, Lawrence and Gordon Roberts. 1993. "Canadian banking solvency, 1922-1940," Journal of Money, Credit, and Banking 25(1): 361-77.

La Porta, Rafael, Florencio Lopez-de- Silanes, and Andrei Shleifer. 1999. "Corporate Ownership Around the World," Journal of Finance 54(2): 471-517. 
La Porta, Rafael, Florencio Lopez-de- Silanes, and Andrei Shleifer. 2000. "Investor Protection and Corporate Governance," Journal of Financial Economics 59(1-2): 3-27.

La Porta, Rafael, Florencio Lopez-de-Salinas, Andrei Shleifer and Robert Vishny. 1997. "Legal Determinants of External Finance," Journal of Finance, July, 52(3): 1131-1150.

La Porta, Rafael, Florencio Lopez-de-Salinas, Andrei Shleifer and Robert Vishny 1998. "Law and Finance," Journal of Political Economy, Dec., 106(6): 1113-57.

La Porta, Rafael, Florencio Lopez-de-Silanes, Andrei Shleifer and Robert Vishny. 2000. Agency Problems and Dividend Policies around the World. Journal of Finance, 55, 1-33.

La Porta, Rafael, Florencio López-de-Silanes, Andrei Shleifer and Robert Vishny. 1997a. "Trust in large organizations," American Economic Review, May, 87(2): 333-9.

Lambton, John George Earl of Durham. 1838. Imperial Blue Books on Affairs Relating to Canada. Republished as Craig, Gerald M. 1963. Lord Durham's Report. Carleton University Press, Ottawa.

Landes, David. 1949. "French Entrepreneurship and Industrial Growth in the Nineteenth Century," Journal of Economic History 9, pp. 45-61.

Levine and King finance and growth

Lunn, Jean. 1942. Economic Development in New France. McGill University PhD Thesis.

Marchildon, Gregory. 1990. Promotion, Finance, and Mergers in Canadian Manufacturing Industry. Doctoral thesis.

Maule, Christopher J. 1966. Mergers in Canadian Industry, 1900 to 1963. Ph.D. Thesis, University of London.

Mauro, Paulo. 1995. "Corruption and Growth," Quarterly Journal of Economics 110(3).

McKay, Paul. 1983. Electric Empire: the Inside Story of Ontario Hydro. Between the Lines: Toronto.

Mills, David M.P. 1872. "Railway Reform - The Canadian Pacific Railway," Canadian Monthly and National Review Nov. 438-439.

Morck, Randall and Bernard Yeung. 2004. "Family Firms and the Rent-Seeking Society," Entrepreneurship - Theory and Practice, forthcoming, 2004.

Morck, Randall, Andrei Shleifer and Robert Vishny. 1988. "Management Ownership and Market Valuation: An Empirical Analysis," Journal of Financial Economics 20(1/2): 293-315.

Morck, Randall, David A. Stangeland, and Bernard Yeung. 2000. "Inherited Wealth, Corporate Control, and Economic Growth: The Canadian Disease." In R. Morck ed. Concentrated Corporate Ownership. University of Chicago Press.

Murphy, Kevin M., Andrei Shleifer, and Robert W. Vishny 1993. "Why is Rent-seeking Costly to Growth?" American Economic Review, May, 82(2): 409-414.

Murphy, Kevin M., Andrei Shleifer, and Robert W. Vishny. 1991. "The Allocation of Talent: Implications for Growth," Quarterly Journal of Economics, May, 503-530.

Murphy, Kevin., Andrei Shleifer, and Robert Vishny. 1989. "Industrialization and the Big Push," Journal of Political Economy 97, 1003-1026.

Myers, Gustavus. 1914. A History of Canadian Wealth. Chicago.

Naylor, R. Thomas. 1975. History of Canadian Business 1867 -1914. James Lorimer \& Co. Toronto.

Nenova, Tatiana. 2003. The Value of Corporate Votes and Control Benefits: A Cross-Country Analysis. Harvard University Economics Working Paper

Newman, Peter. 1975. The Canadian Establishment.

Newman, Peter. 1981. The Canadian Establishment - the Acquisitors.

Newman, Peter. 1991. Merchant Princes. Penguin Viking.

Newman, Peter. 1998. Titans: How the New Canadian Establishment Seized Power. Viking.

Olson, Mancur Jr. 1963. "Rapid Growth as a Destabilizing Force," Journal of Economic History 23(4): 529-552.

Olson, Mancur Jr. 1982. The Rise and Decline of Nations. Yale University Press. New Haven.

Palia, Darius and S. Abraham Ravid. 2001. The role of founders in large companies: entrenchment or valuable human capital? Unpublished manuscript.

Parkman, Francis. 1867. Parkman's Works. Republished by Little Brown and Co, Boston, 1910.

Pérez-González, Francisco. 2001. Does inherited control hurt firm performance? Unpublished manuscript. Columbia University.

Porter, John. 1965. The Vertical Mosaic. University of Toronto Press. 
Prebisch, Raoul. 1971. Change and Development: Latin America's Great Task. Praeger and the InterAmerican Development Bank, Washington, DC.

Rajan, Raghuram and Luigi Zingales. 2003. The great reversals: the politics of financial development in the twentieth century. Journal of Financial Economics 6991) 5.

Reynolds, Lloyd. 1940. The Control of Competition in Canada. Harvard University Press.

Roe, Mark. 2003. Political Determinants of Corporate Governance. Oxford: Oxford University Press.

Safarian, A.E. 1969. The Performance of Foreign-Owned Firms in Canada. Kluwer Nijhoff: The Hague.

Savoie, Donald. 1990. The Politics of Public Spending in Canada. University of Toronto Press.

Shleifer, Andrei, and Robert Vishny. 1989. "Management Entrenchment: The Case of Manager-Specific Investments," Journal of Financial Economics 25(1): 123-139.

Shleifer, Andrei, and Robert Vishny. 1993. "Corruption," Quarterly Journal of Economics 108(3): 599-617.

Skelton, Oscar. 1965. The Life and Letters of Sir Wilfrid Laurier. Carleton University Press.

Smith, Rogers. 1993. Personal Wealth Taxation: Canadian Tax Policy in a Historical \& International Setting. Canadian Tax Foundation.

Sokoloff, Kenneth L. and Stanley L. Engerman. 2000. "Institutions, Factor Endowments, and Paths of Development in the New World," Journal of Economic Perspectives 14(3): 217-32.

Swatsky, John. 1987. The Insiders: Government, Business, and the Lobbyists. McClelland and Stewart, Toronto.

Taylor, Graham and Peter Baskerville. 1994. A concise history of business in Canada. Oxford University Press

Taylor, Graham and Peter Baskerville. 1994. A Concise History of Canadian Business. Oxford University Press.

Tulchinsky, Gerald. 1977. The River Barons - Montreal Businessmen and the Growth of Industry and Transportation 1837-53. University of Toronto Press.

Urquhart, M.C. 1993. Gross National Product, Canada 1870-1926 - The Derivation of the Estimates. McGill-Queen's University Press.

Weber, Max. 1958. The Protestant Ethic and the Spirit of Capitalism. New York: Scribner's Press.

Willson, Beckles. 1915. The Life of Lord Strathcona and Mount Royal. Boston: Houghton Mifflin.

Wood, Shirley E. Jr. 1983. The Molson Saga, 1793 - 1983. Doubleday. 